San Jose State University

SJSU ScholarWorks

Master's Theses

Master's Theses and Graduate Research

1995

\title{
The Oakland Tribune under Robert C. Maynard and the Alamdeda Newspaper Group : a case study
}

\author{
Nancy Anne Fong \\ San Jose State University
}

Follow this and additional works at: https://scholarworks.sjsu.edu/etd_theses

\section{Recommended Citation}

Fong, Nancy Anne, "The Oakland Tribune under Robert C. Maynard and the Alamdeda Newspaper Group : a case study" (1995). Master's Theses. 991. DOI: https://doi.org/10.31979/etd.rxrg-g5uq https://scholarworks.sjsu.edu/etd_theses/991

This Thesis is brought to you for free and open access by the Master's Theses and Graduate Research at SJSU ScholarWorks. It has been accepted for inclusion in Master's Theses by an authorized administrator of SJSU ScholarWorks. For more information, please contact scholarworks@sjsu.edu. 


\section{INFORMATION TO USERS}

This manuscript has been reproduced from the microfilm master. UMI films the text directly from the original or copy submitted. Thus, some thesis and dissertation copies are in typewriter face, while others may be from any type of computer printer.

The quality of this reproduction is dependent, upon the quality of the copy submitted. Broken or inciistinct print, colored or poor quality illustrations and photographs, print bleedthrough, substandard margins, and improper alignment can adversely affect reproduction.

In the unlikely event that the author did not send UMI a complete manuscript and there are missing pages, these will be noted. Also, if unauthorized copyright material had to be removed, a note will indicate the deletion.

Oversize materials (e.g., maps, drawings, charts) are reproduced by sectioning the original, beginning at the upper left-hand corner and contimuing from left to right in equal sections with small overlaps. Each original is also photographed in one exposure and is included in reduced form at the back of the book

Photographs included in the original manuscript have been reproduced xerographically in this copy. Higher quality $6^{n} \times 9^{n}$ black and white photographic prints are available for any photographs or illustrations appearing in this copy for an additional charge. Contact UMI directly to order.

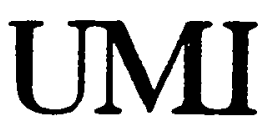

A Bell \& Howell Intormation Company 

THE OAKLAND TRIBUNE UNDER

ROBERT C. MAYNARD AND THE ALAMEDA NEWSPAPER GROUP:

A CASE STUDY

\begin{abstract}
A Thesis
Presented to

The Faculty of the School of Journalism and Mass Communications

San Jose State University
\end{abstract}

\author{
In Partial Fulfillment \\ of the Requirements for the Degree \\ Master of Science
}

by

Nancy Anne Fong

May 1995 
UMI Number: 1374582

Copyright 1995 by Fong, Nancy Anne

All rights reserved.

UMI Microform 1374582

Copyright 1995, by UMI Company. All rights reserved.

This microform edition is protected against unauthorized copying under Title 17, United States code.

\section{UMI}

300 North Zeeb Road

Ann Arbor, MI 48103 
APPROVED FOR THE SCHOOL OF JOURNALISM AND MASS COMMUNICATIONS

Dand L. Ger

Dr. David L. Grey

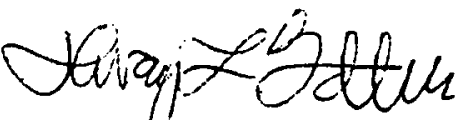

Dr. Harvey Gotliffe

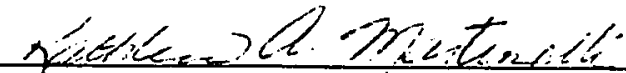

Dr. Kathleen Martinelli

APPROVED FOR THE UNIVERSITY

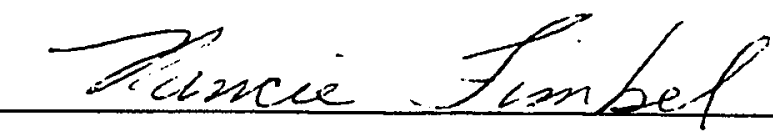


C)1995

Nancy Anne Fong

ALL RIGHTS RESERVED 


\section{ABSTRACT \\ THE OAKLAND TRIBUNE \\ UNDER MAYNARD AND ANG: A CASE STUDY \\ by Nancy Anne Fong}

This was a case study of the Oakland Tribune, a metropolitan daily in the East Bay stretch of the San Francisco Bay Area region, beginning with the ownership of Robert C. Maynard, from 1983-1992, and from 1992 through 1994, under the Alameda Newspaper Group (ANG).

Staff interviews revealed that each owner had a distinct vision for the newspaper. Each owner's vision was discussed within a larger economic, geographic, and technological context. The local economic and geographic conditions led one ownership to redefine the newspaper's audiences and the other to integrate the newspaper's editorial and production arrangement in order to secure economic viability.

A content analysis revealed both owners created similar news products in terms of news type and geographic focuses. Similarities were attributed to the fact that both owners operated under comparable geographic and competitive circumstances. It was found that racial and gender diversity among news staff declined in times of economic uncertainty. 


\section{Acknowledgements}

I would to like to extend my appreciation to all the Oakland Tribune and Alameda Newspaper Group folks that shared their experiences with me. This study was only possible because of their cooperation and thoughtful answers. In particular, I'd like to thank John Raess for introducing me to many of the interesting and dedicated people whom I've talked to for this thesis.

Thanks to all of my advisors who were my extra eyes, when I felt I could no longer edit another page. They offered me words of encouragement and pushed me forward when I wanted to give up. In particular, I'd like to thank Dr. David L. Grey who introduced me to John Raess, and sat through many, many question-and-answer sessions on the particulars of Bay Area journalism and the psychology of journalists. He was readily available and provided gentle criticism and much, much needed advice.

I'd like to thank Jocelyn Dong, a fellow mass communications graduate student who waded through hours and hours of Oakland Tribune reading for this study's content analysis findings. She patiently listened as I thought out loud--working out ideas related to this thesis.

Finally I'd like to thank my family. Without their support, I could not have furthered my journalism education. I'd like to thank Emma, who played editor. I'd like to thank my Mom and Dad who kept the faith, and in the final moments, sat up with me to calculate percentages and recheck the math on the tables for this study. Most importantly, they continued to believe in me and cheer me on when I needed it most. 
Table of Contents

Chapter One: Introduction

Chapter Two: A Literature Review__ 19

Chapter Three: Method___ 44

Table 1: Intercoder Reliability Test Results___ 64

Chapter Four: The Maynard Tribune

Figure 1: An Oakland Tribune Time Line from Maynard to ANG__ 69

Chapter Five: The Oakland Tribune and Its City____ 97

Chapter Six: The Alameda Newspaper Group Tribune___ 116

Chapter Seven: Content Analysis Findings and Interpretation___ 129

Chapter Eight: Summary and Conclusion__ 148

References__ 160

Appendix: Individual Circulation Figures 1984/85-1995_167 167

vi 
Table of Lists

List 1: Standard Interview Questions

46

List 2: Study Participants and Individuals Declining to be Interviewed 47

List 3: Geographic Categories 54

List 4: News Type Categories 56 


\section{List of Tables}

Table 1: News Type Percentages of News Coverage 132

Table 2: News Type Numbers of News Coverage 134

Table 3: Geographic Area Percentages of Metro/Suburban Areas 138

Table 4: Geographic Area Numbers of Metro/Suburban Areas 139

Table 5: Diversity Percentages of Columnists 142

Table 6: Diversity Numbers of Columnists 143

Table 7: Diversity Percentages of Staff Writers 146

Table 8: Diversity Numbers of Staff Writers 147 


\section{Chapter 1}

Introduction

This is a case study of the Oakland Tribune, a major metropolitan daily located in the East Bay stretch of the San Francisco Bay Area region. The objective of this study was to trace the history of the Oakland Tribune under the ownerships of Robert C. Maynard, from 1983 through 1992, and the Alameda Newspaper Group (ANG), from 1992 through 1994.

On April 30, 1983, after months of negotiations, Robert C. Maynard purchased the Oakland Tribune from media conglomerate the Gannett Company.

Maynard's purchase was significant on many levels. Industrywide, Maynard's act reversed the prevailing U.S. trend toward chain ownership, and he became the first black to own a major metropolitan daily. Locally, the East Bay communities now had a hometown owner. From a business standpoint, Maynard had purchased the Tribune for $\$ 22.5$ million--with almost no money of his own in a leveraged buyout. Seventeen million dollars of the $\$ 22.5$ million came from Gannett.

Maynard's reputation as a journalist plus the many "firsts" achieved by becoming owner added to the collective hopes of those in the community and the industry that he would succeed where previous owners had not. Significantly, people believed that the things that Maynard stood for and championed would be reflected in the staff and the pages of the Tribune. Maynard's accession to owner was therefore a symbolically significant moment in newspaper history. 
Those who knew him or knew of him had every ieasun to believe that, as someone who came up from the editorial ranks, he would bring solid, quality journalism to the pages of the Tribune. Those who knew him during his days as teacher and director of the Institute for Journalism Education and the Summer Program for Minority Journalists had every reason to believe that Maynard would work toward increasing diversity in the Tribune newsroom.

The mere fact that Maynard had broken such immense new ground provided the impetus for this case study of the Tribune under him. What was Maynard's editorial vision for the Tribune? Was he able to realize that vision? What happened to that vision after ANG became the owner?

Although the era under ANG furnished contemporary information on the Tribune today, the primary focus of this study was the Maynard era. Direct comparisons could not be adequately made because of the different time frames involved. The Maynard era lasted nine years. ANG has been in Oakland for a little more than two and one-half years.

The value of examining the Oakland Tribune beyond the Maynard era rested in the fact that a comparative study allowed the differentiation of the factors that were common or specific to the Maynard and ANG Tribune. A comparison provided some clues about the larger variables that influenced the editorial product beyond ownership. Lastly, it provided insight of a metropolitan daily in transition. 
Over the near-decade that Maynard was owner of the Tribune, he drew both praise and criticism from his staff. He was nationally prominent and well regarded in journalism circles. His wife and partner, Nancy Hicks Maynard, was a former journalist with the New York Times, and she worked closely with her husband in his lifelong endeavor to increase diversity in America's newsrooms. Both worked to create programs geared toward increasing diversity in the newspaper industry before finally coming to Oakland, CA, to take on the uphill battle of owning, operating, and managing the Oakland Tribune.

That was in 1983. Today, the Tribune is owned by the Alameda Newspaper Group (ANG). ANG also owns four other daily newspapers in the East Bay: the Alameda Times-Star, the Hayward Daily Review, the Fremont Argus, and the TriValley Herald in Pleasanton. The acquisition of the Tribune in late 1992 by ANG initially created quite an uproar among competing local newspapers, Tribune readers, and staffers. However, it had been predicted that if the Tribune were to go up for sale, ANG owner Dean Singleton would be the most logical buyer because ANG already had a foothold in the East Bay market with his four other dailies. Also "Dean Singleton ha[d] become legendary for buying operations that other large companies could not make work" (Rapaport, 1989, p. 156).

The question of ANG's commitment, preparedness, and fitness to take on a tough urban market like Oakland permeated the Tribune newsroom and the pages of competing media. 
How well equipped either owner was, in terms of understanding the market and possessing the adequate resources to operate and manage the Oakland Tribune, was a question that was pertinent to and explored in this case study. This study examined the newspaper's content, organizational constraints, and the environmental constraints of geography, technology, aird economy that both owners operated under.

Maynard and ANG not only represented different ownership types--independent versus group--but also different journalistic traditions. Maynard came from an urban journalism background. ANG was mostly known as a suburban chain with papers in Hayward, Fremont, Pleasanton, and Alameda.

It was July of 1985 when ANG owner William Dean Singleton publicly appeared on the Bay Area journalism scene. It had been two years since Maynard had taken over the Oakland Tribune, and he was competing with newspaper owners Dean Lesher in Contra Costa County and Floyd Sparks in southern Alameda County for new readers. At that time, the collective hopes of Tribune readers and staffers were still high that Maynard could turn the Tribune around.

It was during this period that newspaper owner Floyd Sparks surprised local newspaper pundits and practitioners by striking an agreement to sell his Hayward, Fremont, and Pleasanton newspapers to Dean Singleton, putting Singleton in direct competition with Maynard.

Originally from Texas, Singleton owns Texas-based MediaNews, parent company of ANG. As of November 14, 1994, MediaNews owned 74 newspapers 
nationwide, including the Alameda Newspaper Group papers. Twenty-one of those 74 newspapers were dailies.

The close of the 1980s brought recessionary times to many newspapers across the nation, including the Tribune. It was a gloomy period for the metropolitan daily. The Oakland area suffered two natural disasters: Northern California's Loma Prieta earthquake in 1989 and the Oakland/Berkeley hills fire in 1991. In 1987, Maynard had been diagnosed with prostate cancer. The paper endured, but the collective circumstances took their toll economically and emotionally on all involved. In 1992 , Maynard's cancer recurred. In that same year, the Oakland Tribune was sold to ANG's Dean Singleton for a sum reported to be close to $\$ 10$ million. In August 1993, Maynard succumbed to the cancer.

The arrival of ANG in Oakland contributed to already frayed nerves at the Tribune. Singleton had a reputation for buying financially troubled small-to-mediumsized circulation dailies, returning them to profitability with drastic cost-cutting measures. Singleton made his first entry into a metropolitan market with his purchase of the now defunct Dallas Times Herald in 1986. (The Dallas Times Herald was purchased by Singleton business partner, John Buzzetta, in 1988, and it folded in December of 1991.) A year later in 1987, he purchased the Denver Post and the Houston Post. (The Houston Post was sold to the Hearst Corp., owner of the rival Houston Chronicle, and closed April 18, 1995.) The acquisition of the Oakland Tribune in 1992 was not Singleton's first metropolitan daily purchase. 
Nevertheless, loyal Tribune readers balked at the notion of a largely suburban chain trying to run a major metropolitan daily. Internally, Tribune staffers were dismayed by the immediate layoffs of friends and co-workers. It was reported that only 200 out of the original 600 Oakland Tribune workers were rehired. The one-third rehired had to quickly adjust to the new editorial offices at Oakland's Jack London Square. They now shared half their office space with ANG reporters and editors. News deadlines and production routines were different. Production facilities were now in Hayward and Pleasanton. The Maynard era was over, and a new era had begun under ANG in December 1992.

This is the story of the Oakland Tribune, how its links to its community and its city were broken, forged, and reestablished; it is the larger story of a metropolitan daily in $t_{i}$.nsition.

$\underline{\text { Problem }}$

The Oakland Tribune under Maynard had been the subject of several in-depth magazine and newspaper articles. Maynard's purchase broke new ground on many different fronts, which made the Oakland Tribune the object of intense speculation, scrutiny, and future predictions. The articles written have been qualitative in nature and none have (a) traced the history of the Maynard and ANG Tribune together; and (b) performed a content analysis looking at ownership influence on the Tribune's editorial pages, examining those issues that Maynard was widely known to represent-diversity and total community coverage. 
This case study took a qualitative but systematic approach toward the data collected from the interviews. The information derived from the interviews was utilized two ways: in an historical analysis and a content analysis. The historical analysis allowed a retelling of the 11-year period. The content analysis allowed a systematic evaluation the newspaper's performance in accordance with Maynard's broader vision.

How is newspaper performance evaluated? The use of industrywide, objective standards of newspapers are one option, but such measures tend to be subjective and sometimes will differ among media professionals.

For this reason, this study evaluated the newspaper by the implied principles and explicit objectives set by the organization's leaders. The work of comparing content with asserted or declared objectives is a common approach used in content analyses. Bernard Berelson (1952) said, "Every communication outlet has an objective or a set of objectives, whether implicit or explicit. One measure of the quality of the content is the extent to which it faithfully expresses such objectives" (p. 52).

In this study, the objectives of the Maynard organization were determined through interviews with news staff, top editors, and executives of the Tribune under Maynard. From 24 individual accounts, the author gleaned two consistent themes that best embodied what Maynard represented and subsequently became part of his vision for the Oakland Tribune. The objectives of that vision were (a) newsroom diversity and (b) total community coverage. The content analysis provided some indication of 
whether he was able to realize his vision of (a) diversity, and (b) covering the community in its entirety.

Research Questions

1. Did the levels of racial and gender diversity among Oakland Tribune newsroom staff and columnists change as the ownership changed?

In analyzing diversity, all bylines that were identified as "staff writer" or "staff written" were recorded. Later, with the aid of Tribune personnel, the autliơr obtained a count of those reporters by race and gender.

2. Which communities did Maynard and ANG cover? As determined through interviews, the Tribune had a metropolitan core and suburban audience. How much coverage did each receive during each ownership period?

In examining total community coverage, news stories were grouped into geographic areas and later then placed into categories of news, with the overall goal of obtaining data indicating geographic focus and news type focus of each ownership period.

\section{Content Analysis Assumptions}

A basic assumption of the content analysis was that Maynard shared his philosophies and desired goals for the Tribune with his management and editorial staff. It is assumed that if Maynard did not clearly articulate his philosophies and desired goals to his staff, he would have limited the possibilities for successful implementation 
of them. It is assumed that over the nine-year period of ownership, he explicitly and informally disseminated his personal philosophies and his vision for the Tribune.

This fact was evidenced through the responses of many of the interviewees, who associated Maynard as a advocate for diversity and total community coverage. These two issues were most frequently discussed in answer to the question: What was Maynard's editorial vision was for the Oakland Tribune?

The answers that flowed from that question were spoken in many ways but all revolved around the broad goal of covering and serving the entire community and diversity.

The Oakland Tribune from May 1, 1983, through December 31, 1994, furnished the basic information from which this study drew its content analysis findings. The content analysis findings and interpretations are in chapter seven. The chapter attempted to illuminate the relationship between the Tribune's editorial content and its owner's objectives of (a) total community coverage, and (b) newsroom diversity.

The next chapter is a literature review of what has been written on the Tribune, up until now, including: in-depth articles, Maynard profiles, studies of ownership influences on the editorial product, histories of the newspaper industry and its changing character, and studies on minority news coverage and hiring.

Chapter three is a explanation of the methods used in this study. 
Chapter four pieces together significant events of the nine-year Maynard period using interviews with management and newsroom individuals. A majority of these individuals believed in Maynard's original vision and worked toward making it a reality.

Chapter five continues the Maynard Tribune story in environmental context by examining the larger constraints of geography, economics, and technology. The larger aim of this chapter was to try to establish important linkages--how the history of cities and newspapers was inextricably connected, and how cities are tied to the outer suburbs. Specifically, this chapter drew the links between Oakland and the Oakland Tribune. It described how the relationship between its city and its newspaper was unlinked under the Knowland family, as the face of its downtown changed, and as the city's demographics shifted. Then with the parallel development of the suburban newspaper, the chapter drew the suburban connection that seemed necessary for the Tribune's growth and continued survival.

Chapter six presents the Oakland Tribune under ANG. It looked at what has changed, what has remained the same, and what the future holds for the metropolitan daily.

Chapter seven presents the findings and interpretation of the content analysis of Oakland Tribune.

Chapter eight is the summary and conclusion. 
In telling the story of the Oakland Tribune, the author acknowledges there may exist individuals who had some involvement in the affairs of and something to say about the Oakland Tribune story yet will remain unheard because they declined to be interviewed or because they could not be reached.

Maynard was a pioneer on many fronts. Even though he may have not liked being known as the first black editor, publisher, and owner of a major metropolitan daily--he was. It may be true that his being black was incidental to his accomplishments, but the fact remains his race was always noted by outside observers and media people in association with his achievements. The racial undertones of the situation may have made it difficult for some people to talk or be openly critical about the thornier business issues. In some circumstances it made it impossible for the author to obtain some interviews with key business people.

The level of emotion ran high for those closest to the situation and the passing of time has not dissipated some of the sensitivity. This fact may also have contributed to some individuals' reluctance to be interviewed. Most central to the study was Nancy Hicks Maynard, who declined to be interviewed, citing a lack of time and a belief that the existing participants were sufficient to meet the purpose of this study. So in retelling the story of the Maynard Tribune, some pieces were lost.

It is unfortunate that individuals who declined to participate or may have had enlightening things to say will go unheard. This study will be unavoidably skewed toward those individuals who were willing to be interviewed. 
Historical Background: Knowland to Gannett

The Oakland Tribune was born in 1874 as the Oakland Daily Tribune. It was more of a handbill than a newspaper. It went through a series of owners, including William E. Dargie, before Joseph Russell Knowland became publisher in 1915, beginning the Knowland family's 62-year reign.

The Oakland Tribune had its heyday under the politically influential Knowlands. It was reputed to be a quality newspaper even if it was known for its Republican bias--it was the GOP north and the Los Angeles Times, the GOP south. Joseph Russell Knowland was a prominent figure in California politics in the early half of the twentieth century. His personal politics set the tone of the newspaper's editorial coverage (Goodman, 1974).

Yet by the late 1960 s, the Knowland family Tribune along with its city had begun to wane. By largely ignoring the changing realities of Oakland and not taking advantage of suburban growth, circulation slid from the $230,000 \mathrm{~s}$ in the mid-1960s to the $180,000 \mathrm{~s}$, a decade later. In 1979 , Oakland's population shifted from a white to black majority. The black majority in Oakland found its communities ignored by its city's newspaper (Rivers \& Rubin, 1971).

Today, Knowland Park in the Oakland Foothills is one of the few physical landmarks named for the Knowland family. It was dedicated by the Native Sons and Daughters of the Golden West to the former U.S. Senator and son of the founder of the Tribune, William Fife Knowland. 
Like his father, William Fife Knowland was a conservative Republican-patriotic, and foremost an Oakland booster. He was only 24 years old when he was first elected to the State Assembly. After a single term in the lower house, he was elected to the State Senate. In 1945, he was appointed by longtime Knowland family friend Governor Earl Warren to the U.S. Senate. The appointment was made after the death in office of Senator Hiram Johnson.

The family-owned Tribune was a powerful voice for the Republican Party and the politics of the younger Knowland, who had presidential ambitions. The newspaper was chiefly recognized as a voice for the status quo up to the time that William Fife Knowland left the U.S. Senate to run for governor of California in 1958. At the time, he believed that the way into the nations's highest executive office was through the governor's office and not through the Senate. That belief, in effect, ended his political career.

William Fife Knowland was defeated in his gubernatorial bid by the Democratic candidate, Edmund G. Brown. Knowland left politics for good and returned to the newspaper business.

The late 1960s and 1970s ushered in a new era in politics, not only in the city of Oakland but across the nation. Urban decay and the flight of the white middle-class to adjoining suburbs contributed to the decline of the city and its paper. The situation worsened when burgeoning suburban newspapers closed in to compete for advertisers. 
The changing social landscape was the beginning of the end of the Knowland dynasty. The conservative agenda of the newspaper as well as the decision to pull out of the suburbs to become a regional newspaper contributed to the decline in circulation and influence. Time magazine reported:

While Knowland and his father, who bought the Tribune in 1915, pushed for projects such as the San Francisco-Oakland Bay Bridge, a museum and an airport, readers found hardly a word about poverty, the suburbs or the city's rapidly growing minority population (Schardt, 1979, p. 89).

In February 1974, the Tribune celebrated its 100th anniversary. A week later Publisher William Fife Knowland committed suicide. His death eventually led to the sale of the Oakland Tribune to Phoenix-based Combined Communications in 1977, closing the chapter on the Knowland family's ownership of the Oakland Tribune.

In the city of Oakland itself, many middle-class whites were leaving the city for the adjoining suburbs. Inside Oakland, the minority population rapidly grew. Yet even with a sizeable and growing minority community, the pages of the Oakland Tribune did not reflect the fact that, by 1979 , the city's population was $54 \%$ nonwhite.

Succeeding his father as publisher, Joseph William Knowland recognized that the newspaper had failed to fully serve the local community. In response, he encouraged his executive staff to involve themselves in the black community and find out what it is all about. The new openness, however, did not immediately improve the 
newspaper's waning circulation or its conservative image as the voice of the establishment.

All changes or improvements were derailed in 1977, by squabbling among the surviving heirs of the Knowland estate. The Tribune was sold to Karl Eller's Phoenixbased Combined Communications, Inc. for $\$ 17.8$ million (Endicott, 1979, p. 1).

Under Combined, the new owner struck "Oakland" from the newspaper's title in an effort to attract greater regional circulation. Still the newspaper continued its circulation slide. Harry Harris, veteran police reporter, said of Combined Communications:

They were just in there to ruin people's lives in my opinion. They probably came in with orders to cut all costs and get rid of all old-timers. They made life so miserable for some of our veteran reporters--changing their schedules, pulling them off their beats. They just made it horrible for them (recorded interview, June 12, 1994).

Then in 1979 , the future began to look a little brighter when Combined Communications was merged with media giant Gannett Company. Gannett acquired the ailing Tribune as part of the merger. Seventy-eight papers strong, Gannett wrapped up one of the largest media deals of all time, acquiring seven television stations and 12 radio stations, an outdoor advertising group and the Cincinnati Enquirer.

Three years of Gannett ownership gave the Tribune a completely new look. "Oakland" was returned to the newspaper's name. Several months into the Gannett 
ownership, the Oakland Tribune started publishing Eastbay TODAY (EBT) in addition to the afternoon Oakland Tribune. EBT sold for 10 cents a copy and was sold only at racks and newsstands. Its slogan--"Reach for the Peach"--was coined for its peachcolored business and sports sections. In reality it was a sunrise edition of the Oakland Tribune.

At the time, Robert Maynard, who was then serving as an affirmative action consultant for Gannett, was appointed editor of the newspaper. In addition to cosmetic changes in format, typography, and headlines, Gannett added 26 editorial positions, called the "Maynard 26." Half of the new hires were minorities and women (Endicott, p. 10).

In 1981, Gannett appointed Maynard as publisher. In September of 1982, Gannett announced its intention to purchase KRON-TV in San Francisco but because of FCC regulations prohibiting cross-ownership in the same market, Gannett announced it would have to sell the Oakland Tribune. Media observers noted that there was no talk of selling the Independent Journal (I-J) in Marin County which was also located in the same market. The I-J had color presses that would later become necessary in the printing of USA TODAY.

Seven months after Gannett's announcement, Maynard emerged as the Tribune's new owner. "We had other prospective buyers, but we felt it desirable for the community to have a dedicated local owner," said Gannett Chairman Allen Neuharth (Time, 1983, p. 85). 
Newsweek reported that as editor and publisher, Maynard had a running start. As owner, Maynard was quoted by the Tribune as saying that he would basically be "fine-tuning" changes already made:

Under Maynard, who had been running the Gannett-sponsored Institute for Journalism Education at the University of California at Berkeley, the Tribune expanded its editorial staff, hired more nonwhite reporters and turned its sights back on the city's seamier realities with some award-winning local reporting (Gelman \& Joseph, 1983, p. 93).

Several months after the sale of the Oakland Tribune, in the fall of 1983, Gannett and the Chronicle Broadcasting Company jointly announced that they had called off their agreement for Gannett to acquire KRON-TV.

Although never fully explored in print, it was widely believed that Gannett wanted out of Oakland but needed a legitimate reason like the KRON-TV purchase. In 1982, the year before the Maynard purchase, the Oakland Tribune lost $\$ 3$ million (Gelman \& Joseph). Both facts may have contributed to Gannett's generous \$17 million loan toward the Maynard sale.

Gannett was now busy with USA TODAY, which was launched just a year earlier. It was touted as "the country's first national, general-interest daily newspaper" (Prichard, 1987, p. 1). Neuharth had staked millions of Gannett's dollars and his own reputation on making this newspaper a success. An Esquire magazine profile of Neuharth observed, "The fact is that Neuharth seems reluctant to commit himself fully 
to the best quality journalism if there is the slightest chance that the investment community might sense some risk to Gannett's ever upward profit curve" (Shaw, 1979, p. 70). The one exception seemed to be USA TODAY, his pet project.

Other newspapers in the giant chain were still required to be profitable. The fact that the Oakland Tribune was not was what undoubtedly led its sale. 
Chapter 2

\section{A Literature Review}

The Oakland Tribune under Robert Maynard has been the subject of many newspaper articles and several in-depth magazine articles but no academic case studies. This literature review first examined what those newspaper and magazine accounts have said. Next, this chapter established linkages to past literature that had significant bearing on a case study of the Maynard and ANG Tribune as it underwent ownership and industry transitions.

This chapter reviewed the literature on (a) ownership structure and its relationship to the news product, specifically local news; (b) recent marketplace and industry changes, and (c) the history of minorities in U.S. newsrooms and as news subjects.

Before the Maynard purchase, the general prognosis for the Oakland Tribune was not good. When Maynard emerged as owner, most chroniclers of the Tribune at best expressed veiled optimism at the prospects of Maynard ever healing the "sick man of Bay Area journalism" (Rapaport, 1989, p. 134). Still, most Tribune watchers kept their fingers crossed for the revival of the newspaper under Maynard.

The consensus of the dozen or so newspaper and magazine articles reviewed was that Maynard's charge would be an uphill battle, with the odds of success poor, given the earlier history of the metropolitan daily itself and the region at large. 
Rivers and Rubin (1971), in a qualitative evaluation of Bay Area journalism called "A Region's Press: Anatomy of Newspapers in the San Francisco Bay Area," named the ingredients necessary for a great newspaper:

The first necessity is an owner who is determined to produce a great paper and knows how to go about it. ... The market for the paper must be large enough to provide revenues enabling the owner to pay for a quality product. The community served by the paper must be large. The intellectual level must be such that the readers will feel rewarded by an informative paper, rather than repelled by it. The effort to set the paper on the path toward greatness must be properly timed (p. 149).

They bemoaned the fact that in a region such as the Bay Area, there existed no newspaper that they could truly call great in journalistic terms. In their evaluation of the Tribune overall, they said, "In sum, the Tribune is better than its reputation. The Tribune leads the Bay Area in regional government and environmental issues coverage." They wrote the Tribune's day-to-day coverage resembles the San Francisco Examiner "in its handling of local, national and international news and its conservative approach" (p. 50-51).

One of the earliest articles written about the Maynard Tribune was by Dwight Holing in a 1984 SF Focus magazine article entitled "Pressing Business." He described 
the circumstances of the Oakland daily before Maynard became owner:

Not long ago no media observer would have given the 110-year-old Oakland daily a chance of surviving such a financial squeeze. After all, years of revolving-door ownership, declining revenues had left it weak and defenseless (p. 48).

Holing's article was written a year after Maynard took ownership. Holing presented a descriptive profile of Maynard as someone accustomed to bucking the odds, possessing unflappable optimism, boundless energy, and deep conviction.

The article recognized the intense competition from the San Francisco Chronicle and Dean Lesher's papers in Contra Costa County. As a result, Holing took a hopeful yet cautious wait-and-see approach to the Tribune's future success:

Whether or not Maynard can fend off his opponents and gain new ground at the same time remains to be seen. Financially, the paper has exceeded projections since he took over. Maynard predicts the Trib will be profitable by 1986. Analysts have revised their expectations since he took over as well. Though none are willing to come right out and say the paper will definitely succeed, some are expressing hope where once only doom prevailed (p. 127). Four years after Holing's article appeared in SF Focus, (East Bay) Express reporter Mike McGrath (1988) tackled the subject of the Maynard Tribune in a twopart series entitled "The Strange Case of the Oakland Tribune." McGrath was allowed to be a participant-observer in the Maynard newsroom. He recounted Tribune history 
back to the Knowland family, who owned the newspaper from 1915 to 1977 . In 1988 , he painted a portrait of a financially troubled newspaper. "Chronic financial problems have caused major cutbacks in all departments--culminating in the recent ten percent across the board cut in the editorial staff" (p. 10).

In his analysis, McGrath argued that the decisions of previous owners limited the chances of success at the Maynard Tribune. More precisely, McGrath argued that the current Tribune was still paying for the Knowland decision to pull out of the suburbs that were explosively growing during the 1960s:

Quite clearly the time to have pushed for a quality newspaper would have been during the great suburban expansion of the ' $60 \mathrm{~s}$, and well before the recessions of the '70s and early '80s. My own feeling is that William Knowland has to take the rap for not doing it then. Whether it was because of their preoccupation with right-wing politics, or their curious aversion to modernity, the Knowlands, Joe and Bill, had much to do with making the Tribune what it is today--an inconsistent, economically marginal newspaper with a seemingly permanent identity crisis (p. 20).

SF Focus magazine returned to the subject of Bay Area journalism once again in 1989. This time with all the major daily newspaper players in a two-part series entitled "Newspaper Wars" by Richard Rapaport (1989). Rapaport played out the potential journalism scenarios the Bay Area could face by the year 2000 . 
In his report, he wrote the Tribune faced major stumbling blocks on the road to financial viability, including mounting interest payments on the loan from Gannett and the uncertainty of a downtown retail revival.

The prognosis in 1989, as in 1984, was not good but the hope was held out that just maybe Maynard could pull it off. He wrote, "Although the newspaper has yet to put its financial difficulties behind it, its leadership is determined to make it." He quotes an unidentified Tribune employee who said, "'People have been writing the Tribune's obituary since young Joe Knowland took over and it ain't dead yet'" (p. 145).

Yet unlike earlier articles, Rapaport looked at the possibility of the Maynard Tribune ceasing to exist and beyond. According to Rapaport, the competition was poised to move in:

The Singleton papers are also arrayed against the Oakland Tribune. Halvorsen [a former San Francisco Examiner editor who was brought in by Singleton to run $A N G]$ professes to be interested in being 'the dominant paper in the east bay.' And while he won't come right out and say it, there is a sense that if the Tribune falters, or goes up for sale, Dean Singleton will be one, if not the most logical, of the potential buyers (p. 134).

Rapaport's report was one of the latest articles written on Bay Area journalism and the Oakland Tribune. There has not been another since ANG took ownership of the 
Tribune in late 1992--as was predicted in Rapaport's report. Rapaport did not organize his report using any type of theoretical framework.

Of the articles and studies on the Tribune reviewed, Rodney Stark's (1962) "Policy and the Pros: An Organizational Analysis of a Metropolitan Newspaper" came closest to providing a theoretical framework from which to organize data amassed during his two-year participant-observer stint as an Oakland Tribune reporter and rewrite man. Most of the data was collected as Stark described, "from relatively unstructured interviews conducted with staff members . . " (p. 12). For this reason, as well as the age of the study and the ownership (the Knowland family) in charge at the time of Stark's study, his work mainly provided an historical examination of the Oakland Tribune newspaper staff at work. Since it was written, the Tribune's culture, organizational structure, and ownership have changed. When the older William Knowland died, the right-leaning politics of the Knowlands disappeared from the pages of the Tribune. The culture and the newspaper's organizational structure underwent several transformations--as several owners came and went--all in one-third the time that the Knowlands owned the Oakland Tribune.

Since the Knowlands, the Tribune has had four owners. Only two out of all five Tribune owners were local and independent. The remainder were out-of-state and part of a chain or group. Since 1920, chain ownership in America has grown steadily, by 1940 chain ownership surpassed independent ownership. (Busterna, 1988). 
In 1984, one year after Maynard took independent ownership of the Tribune from the Gannett chain, U.S. daily circulation under group ownership accounted for $79 \%$ of total national circulation. Sunday circulation under group ownership amounted to $88 \%$ of total U.S. Sunday circulation (Editor \& Publisher, 1984).

The literature on ownership type influences had bearing on this case study for the following reason: the Tribune under Maynard existed as an independent institution. Now, under ANG the Tribune is part of a group that is owned by national chain Texas-based MediaNews. What difference ownership type has had on staff diversity and selection of news type and locale is part of the content analysis examination.

In reviewing studies of chain versus independent newspaper literature in the past decade, primarily three approaches have been used by media researchers. They were (a) content analyses, (b) employee surveys, and (c) participant observation. The content analyses examined manifest content; surveys analyzed employee perception and attitudes; and participant observation studies analyzed employee interaction. Regardless of the method used, all studies have considered whether ownership type had any influence on editorial content.

Many studies have observed that chains today are sensitive to criticism or charges of editorial interference. This development has provided chain-owned newspapers with some degree of protection from open editorial interference by its owners. 
What is more likely is the presence of indirect influences as discussed in Breed's (1955) seminal participant-observer study. Breed wrote that newspaper policy was not directly implemented but rather subtly exercised using what he called "socialization forces." This phenomenon of indirect policy implementation was also documented by Stark (1962), in his thinly disguised study of a metropolitan newspaper he named the "Express." His descriptions of the Express newsroom and its owners allow readers familiar with Tribune history and the landmark Tower to conclude that the paper being studied was the Oakland Tribune under Knowland ownership:

The Express is a major American daily and Sunday newspaper located in a large metropolitan area with a circulation in excess of 200,000 daily. It is in competition with several other daily newspapers published in the same metropolitan area among which it is neither the most, nor least, financially successful, respected, established, and widely read. Additionally, a host of smaller daily papers proliferate in the suburbs of the community offering increasing competition. The plant and editorial offices occupy a deteriorated landmark in the heart of the congested business district. But the paper has no indebtedness and has returned excellent profits for many years. All newsgathering and writing activities are confined to the building's fourth floor where the newsroom, the publisher's offices, and the offices of special departments are located ... (p. 12). 
In reinforcement of Breed's findings seven years later, Stark argued that the tools of policy implementation included praise, reward, and promotion. Reporters that wrote according to publisher policy were rewarded with the best beats and promoted quickly. Those that did not were relegated to unpopular beats and did not move up in the organization. He also wrote that there existed a constant tension between the organizational men and the what Stark called the "pros" or professional men. The organizational men carried out the policies of the owner but were described as less than capable of putting out a quality newspaper--that required the enlistment of the pros. Yet the pros very often found themselves at odds with the owner's policies.

In the four decades since Breed's and Stark's studies, most mass communication researchers have employed content analyses, gauging ownership influences on the editorial process by examining the manifest content of a newspaper before and after a change of ownership.

These studies have found decreases in the reporting of local events, a less vigorous editorial page, and a standardizing effect on the type of news covered among newspapers belonging to the same chain. They have also found journalistic improvements in some papers and an increase in national and international news among newspapers acquired by chains.

This case study was primarily concerned with the first two effects because this thesis examined whether the change in ownership had any effect on (a) the geographic location of news covered and (b) the type of news covered. Since there was no effort 
in this study to systematically look at the existence of a standardizing effect or at national and international news coverage among ANG newspapers, the literature was not examined because it had no bearing on this thesis. The literature review focused on the impact of ownership structure on news type and local reporting.

Is there a link between a newspaper's ownership structure and the amount of local coverage that a newspaper offers? Previous studies have tested such links and found that, in some cases, the amount of local coverage has declined in quality or dropped in quantity after a change in ownership. One study found that a drop in local coverage corresponded with an increase in the amount of national and international news (Romanow \& Soderlund, 1988). Another study found that local editorials lacked controversy (Donohue, Olien, \& Tichenor). The subjects of such studies have usually been the largest U.S. chains--Gannett and Knight-Ridder--which dominate in terms of total U.S. circulation. Smaller groups which outnumber giants like Gannett and Knight-Ridder have not been as critically studied.

In his 1979 impressionistic study of Gannett newspapers, N.R. Kleinfield wrote, "My own reckonings [which Kleinfield said were confirmed by several Gannett editors] indicated that many Gannett papers were composed of at least 60 percent wire copy" (p. 52). He explained that although most of the papers examined carried more local news than national and foreign news, "the local news columns tended to be plump with docile town-and-county government stories, generous graphics and photos" (p. 52). 
Using a systematic content analysis, Thrift (1977) compared 16 previously independent West Coast dailies purchased by chains to eight independents and found that the chains used significantly fewer "argumentative editorials in controversial contexts on local matters" (p. 329). Conversely the "[e]ditorial writers for independently owned dailies used a far higher proportion of local editorials with topics in controversial contexts than did writers for chain-owned dailies . . . " (p. 329).

Instead of looking at local editorials, Donohue, Olien, and Tichenor (1985) looked at the conflict reporting of local government issues and its relationship to newspaper ownership and type among 83 newspapers, in 1965 and 1979. Ownership was divided into two categories, in-state and out-of-state. Type was divided into three categories: weeklies, semi-weeklies, and dailies.

Although the number of dailies in the study was small, 21 in all, Donohue, Olien, and Tichenor found that among this group, those newspapers with in-state ownership increased their reporting of local government conflict reporting by up to one-third. Out-of-state ownership newspapers decreased their reporting by nearly onehalf. They concluded that:

The changing pattern of conflict reporting in these community newspapers appears to be related to increased interdependence among communities and substantial changes in the organization of mass communications media, including the pullback of metropolitan newspapers and changes in ownership status of the press (p. 499). 
What all three studies showed was that chains may not only reduce local coverage but may tend to shy away from types of coverage that were considered to be controversial. Still the case can be made for independent newspapers that later became chain-owned having improved or expanded news coverage.

In controlling for ownership type, researchers have found other structural constraints were at play. That is possibly why the results of many chain versus independent studies frequently draw mixed and contradictory results.

A case study by Romanow and Soderlund (1988) showed that among chains themselves, there were differences in news priorities. In their four-year study of content, Romanow and Soderlund found a transfer of ownership from one chain to another led to a decrease in local news with an accompanying increase in national and international news. Interviews with the publisher confirmed that a conscious decision had been made by the newspaper to turn the paper into "'a truly national newspaper." According to the publisher, "The infusion of funds from the new corporate ownership allowed the newspaper to expand its domestic and international bureau coverage"" (p. 11). Romanow and Soderlund concluded that other than the professed reassignment of news categories, there were no other significant differences in editorial content between the two ownership periods. In a later interview with the editor-in-chief, the consistency in editorial categories was attributed to the retention of an editor who remained in place during both of the ownership periods. 
The phenomena of "deep pockets" or greater economic resources--an attribute more commonly associated with chains--has led researchers to ask if chain ownership can improve news quality as a result of greater economic resources. The Romanow and Soderlund study provided some empirical evidence of improvement once a newspaper gained access to greater economic resources and the professional management of a chain. Yet it is important to point out that chains have varying levels of resources and professionalism. Chains also can allocate their resources very differently depending on management decisions regarding the chain's long-and short-term goals. In a published speech, C.K. McClatchy, editor and chairman of the board of the McClatchy Newspaper chain, argued that the differences between chain and independently owned newspapers were the result of individual level decisions. He said, "The difference, I believe, seems to be more a question of the interests, background, and ambitions of the individuals in charge rather than simply the form of ownership" (1988, p. 19).

What effect, if any, does a chain have on the individual attitudes of its newsroom personnel? Researchers have surveyed newspaper management and staff in an effort to answer this question.

Busterna (1989), for example, conducted a survey of managers in an attempt to measure their attitudes toward profit maximization. Managers, he argued, were the people directly responsible for the economic well-being of the organization. Busterna categorized newspapers into two groups, owner-controlled and manager-controlled. Owner-controlled was a situation where an individual "own[ed] a sufficient proportion 
of equity to effectively control the firm's decisions." In a manager-controlled situation the manager lacked such control (p. 303). Busterna found support for the hypothesis that owner-controllers placed a greater emphasis on profits than owner-managers. Based on the study's findings, Busterna wrote, "[W]e now have more reason to believe that the passing of owner-managed, locally controlled newspapers will result in a greater concern for profits, perhaps with less concern for local issues" (p. 307).

Ownership is but one type of structural constraint. Other studies have examined subcategories of structural constraints that may influence the news product (Demers, 1991). Researchers like Demers (1991) have approached the issue of ownership influence from different levels of analysis, explaining the news product as the outcome of individual, organizational, and institutional forces.

So far, in this literature review, ownership type alone has been examined, but other structural influences such as community pluralism and newspaper size and type all affect the news product. Organizational level influences, such as personnel hiring, promotion practices, professionalism, and the routinization of news, all affect the news product. Professionalism offers industrywide standards for the use and non-use of news, layout, editing, ethics, and gatekeeper priorities. News routines like deadlines and space constraints impact the news product. In controlling for ownership type, researchers like Demers (1991) have found that these structural constraints may have a greater impact on the newspaper product. 
Demers (1991) surveyed the highest ranking editors at 200 U.S. daily newspapers regarding their attitudes about their newspaper's emphasis on profits versus product quality. The total response rate was $55 \%$, with $70 \%$ at chain-owned papers and $30 \%$ at independent papers. The responses drew partial support for the hypothesis that chain newspapers were more likely to emphasize profits. Yet there was also support for the hypothesis that the size of an organization is related to its emphasis on profits. When Demers compared larger circulation newspapers with smaller newspapers, he found larger papers, regardless of ownership status, placed less of an emphasis on profits and more of an emphasis on product quality. As originally hypothesized, the study also found that editors of chains did not emphasize product quality more than editors at independent newspapers.

Demers found that the organizational structure of a newspaper impacted editors' attitudes more than ownership type. He found that larger newspapers were more bureaucratic. The specialization and decentralization of functions at larger newspapers allowed editors to devote energies to editorial tasks and removed them from typical economic concerns. In smaller organizations, editors often had to wear several hats including that of business manager and publisher, making them more likely emphasize profitability as an organizational goal.

Industry articles and studies in the late 1980s and early 1990s observed editors becoming more concerned with the bottom-line of their newspapers. Underwood and Stamm (1992) conducted an on-site survey of 429 newsroom staffers at 12 West Coast 
dailies that confirmed industry analysts' views that newspapers were becoming more reader-oriented and market-driven. Their sample included eight small papers (all with circulation under 100,000, four of which were family-owned and four chain-owned), and four large papers (all with circulation over 100,000, two of which were familyowned and two chain-owned).

Journalists in the survey were asked about (a) changes in management policy and their perceptions of the impact of those changes and (b) their perception of how recent changes affected the paper's business/journalistic balance. Underwood and Stamm found:

The strongest differences were between chain-and family-owned newspapers. Compared to family-owned papers, chains were perceived as giving more emphasis to business-oriented policies such as profits and treating readers as customers, while family papers consistently gave more emphasis (than chains) to journalistic principles. In fact, it was only family papers that reversed the general trend of giving stronger emphasis to treating readers as customers than to any journalistic policy. At family papers, editorial autonomy was perceived as getting more emphasis than any other newsroom policy (p. 311).

In their study, the researchers also acknowledged that, even though the newspapers sampled were becoming more reader-oriented and market-driven, this is occurring at the same time journalists see their newspapers still stressing many of the time-honored journalistic values. At both chain and family 
newspapers, traditional news values received stronger emphasis than any business-oriented policy except treating readers as customers (p. 316).

What has occurred in the newspaper industry that has caused greater attention to be paid to the marketplace? As the newspaper industry changes so does the nature of news and the economic structure of news organizations.

Metropolitan papers have been undergoing self-imposed as well as circumstance-forced transformations. Most notable of all, according to Bogart (1982) has been the market-oriented flavor of the news being presented today. The changes have been linked to the demographic shifts of the urban landscape that originally spawned the metropolitan newspaper. In addition to the changed demographics of the inner cities, "[c]hanges in the urban economy and social structure have also had disastrous effects on downtown retailers, who have been the mainstay of metropolitan newspaper advertising" (p. 59). Bogart wrote:

The deaths of great metropolitan dailies are stunning events, and not only to publishers and editors. But do they mean that newspapers, as such, have outlived their function?... The fallen giants in the business have been stricken by the sickness of their home cities (p. 58).

On the other hand, Bogart (1982) noted that in the early 1980s, the dailies without local daily competition, serving smaller and middle-sized communities, kept growing and enjoyed high levels of readership and prosperity. As the newspaper industry entered the 1980s, Bogart observed that it was "not faring badly." In terms of 
advertising, newspapers have held on to their share of advertising investments over the last 12 years--29\% (p. 69).

Yet according to Crutcher (1992), "Since 1988, newspaper advertising growth has not kept pace with GNP growth." However Crutcher predicted a reversal of that trend for the period 1992 through 1995, when advertising revenue would "more closely track GNP growth" (p. 40).

By the 1980s, many newspapers were catering to advertisers by target marketing. "Many [newspapers] are able to provide advertisers with 'pinpoint' coverage in specific areas and to extend their coverage with supplementary distribution of advertising through mail or home delivery to nonsubscribers" (Bogart, 1982, p. 70).

Target marketing has influenced the content of newspapers as well. In a separate study, sponsored by the Newspaper Advertising Bureau and looking at changes in U.S. newspaper content in the past decade, Bogart (1985) found significant changes in the balance of international and national to local news, ratio of features to hard news, and the number of specialized columns. In a survey of 1,310 U.S. daily newspapers representing $77 \%$ of total dailies and $90 \%$ of total circulation, he found that between 1979 and 1983, five times as many papers increased local news at the expense of international coverage. Bogart argued that, "Many editors may have been going this route in the belief that people want 'chicken dinner news' from their newspapers at a time when television is bringing them battle scenes live from the Middle East and Central America" (1985, p. 86). Yet one of the final findings from 
the survey responses with direct relevance to this case study of a metropolitan daily was:

One important development of recent years has been the introduction of geographically zoned editions that include editorial matter as well as advertising. The introduction of zoned editions was in large part a response by metropolitan papers to growing suburban competition and by dailies generally to the rise of free-distributed weekly "shoppers" in the 1970s (p. 84).

Among larger papers, Bogart found that $43 \%$ had added zoned editions. Not only has there been the proliferation of zoned editions but also increased competition has led to more aggressive marketing of papers and a more reader-driven approach--a fact borne out by the Underwood and Stamm study (discussed on pp. 33-34).

More recently, Miller (1992) argued against viewing readers as only a "collection of geographic communities identified by zoned editions . . . Instead, he argues, "the 'community' we serve is actually a collection of many communities, identified and united by race, occupation, hobby, gender politics, and even sexual preference" (p. 25). Miller encouraged newspapers to use this model to be more responsive to their audiences in their approach to news.

The news industry has for many years tried to settle the ongoing debate between providing more market-oriented news or providing news that people need. The issue of providing the news people need was the topic of a 1976 lecture by 
William Hornby, former executive editor and vice president of the Denver Post (which is now owned by Dean Singleton's MediaNews organization):

The newspaper has always needed, and never more than today, a more farsighted management ethic than that based merely on moving to a customer a product he wants. The newspaper is an institution that sets out to do more than just maximize its market. The newspaper is a quasi-public institution with a constitutional purpose which some of its audience may imperfectly understand but which well serves them anyway. The press has never been and never should be in business to give the people just what they want. The editor who does his editing predominantly from market research returns isn't worth a damn (p. 16). More recently, Miller (1992) argued for greater integration of editorial and business departments:

Editors reign supreme in the newsroom caste system, and are reluctant to share turf with artists, research librarians, or heaven forbid--marketing people. Editors know what's best--for the organization and for the readers. Therein lies the problem. Newspapers are suffering on those convictions (p. 25). Whether newspapers were being hurt by what Miller described as traditional convictions was just one aspect of the U.S. metropolitan newspaper's struggle to transform itself. In the name of survival and tradition, the editorial department's struggle for separation from the business department versus integration with the 
business department will continue to be waged. The Oakland Tribune was and is only one battleground of many.

What does the reading audience have at stake? What has been the effect of the trends so far discussed--chain ownership, target marketing, editorial zones, and greater integration of news and business departments? For some readers, it has resulted in diminished access to news in their neighborhoods.

In his 1982 study, Blankenburg hypothesized that chains would artificially control circulation in order to optimize revenue. He compared a matched set of Gannett and non-Gannett newspapers. Blankenburg found that Gannett could and did practice circulation cutting in order to optimize revenues. This had the de facto result of leaving parts of a community without ready access to the company's newspapers. Some dailies have been criticized for neglect--usually editorial--of the inner city; something like "red-lining" for circulation may exist too. On the other hand, some dailies that have withdrawn from distant circulation have kept a policy of serving the core. The forces of marketing don't augur well for distant and low-income populations (p. 397).

Four years before the Blankenburg study, Bagdikian (1978) called this practice a "blackout of news to the central city" (p. 66). Publishers justified this "blackout" based on the difficulty of (a) selling papers there, (b) hiring and keeping delivery people on the job, and (c) a higher rate of nonpayment of bills--which Bagdikian agreed were all true. However, he argued that a newspaper has a greater duty than 
profitability. He attributed newspapers' slight efforts to sell papers in the central city and failure to report on the central city comprehensively to the target marketing of affluent audiences. In his 1978 report, Bagdikian found that $26 \%$ of Los Angeles residents received the Los Angeles Times; 36\% of San Franciscans received the San Francisco Chronicle; and the New York Times got into $11 \%$ of homes in the city of New York.

Seven years later, Wilson and Gutierrez (1985) argued that as the more affluent households left the cities so did the city's newspapers, if not physically, at least in access. As inner cities became more diverse, many big-city newspapers were looking for ways to avoid the potential readers in their neighborhoods, but chasing those who were living in suburban cities and counties. Using circulation strategies that made it difficult, if not impossible, for residents of ghettos and barrios to subscribe to newspapers, some metropolitan newspapers refused to put newsstands in inner-city areas at the same time they were starting or expanding new editions in outlying areas (p. 54).

They explained that "[b]ecause advertisers wanted affluent readers, newspapers and broadcast media targeted their content to audiences in the more affluent, and predominantly Anglo, suburban areas" (p. 55).

At some major metropolitan daily newspapers, increased circulation among affluent readers has become the primary objective and, because minorities were vastly 
underrepresented in the upper-middle to upper-class economic categories, they have been shortchanged in news media coverage (Wilson \& Gutierrez, p. 141). Echoing the concept of total community coverage, Wilson and Gutierrez wrote:

Although news media, operating under the free enterprise system, have every right to pursue profits, they should not do so at the expense of their social responsibility to serve the informational needs of society. The surveillance function of mass communication requires that news media inform society about the perspectives, aspirations, and contributions of all its components (p. 141). Historically, throughout the early 1960 s, news media rarely covered minority communities unless "they were perceived as posing a threat to the established order" or were celebrating "colorful cultural festivals" (Wilson \& Gutierrez, p. 41).

The issue of fragmented community coverage is not new. Bagdikian (1983) drew on his personal experience as a reporter in the 1950s to support his argument for more comprehensive community coverage:

During the emergence of the civil rights movement in the 1950 s, most of the best regional papers, in the North and the South, would tell me when I dropped in for the traditional 'fill-in' for outside journalists, that there was no serious problem in the 'colored districts.' Yet in city after city there came racial explosions that surprised even the local media (p. ix).

The media's collective failure to cover these "colored districts," left the whole nation gaping in astonishment from the violence happening across the nation. 
Harold Jackson (1992) echoed Bagdikian's criticism of the media for failing to prepare the public for the violence that erupted after the 1992 Rouniey King verdict. He wrote:

That most whites had not previously realized the degree of rage among black youths that exploded in the Los Angeles riot can in part be attribited to the media's ineptness in reporting why that rage existed. It didn't start with the Rodney King case. White readers, watchers and listeners of the daily news absorb the fact that homicide has become the leading cause of death among young black men as easily as they wipe up a kitchen counter spill with a Bounty towel. The media have failed to provide them with the perspective to be genuinely touched by such numbers (p. 15).

In a search for solutions and change, Wilson and Gutierrez argued that minorities have historically had three options:

"(1) they may seek access into the majority media through employment; (2) they may develop and maintain their own communications media; or (3) they may apply pressure techniques of various forms to effect changes in majority media content as it relates to them" (p. 198).

They continued:

Individual activists also have aimed their efforts directly at newspapers and achieved some success in keeping the issue before the industry. Among the leaders who emerged in the mid-1970s to mid-1980s were Robert Maynard and 
Nancy Hicks (instrumental in founding the Institute for Journalism Education, among other efforts) (p. 207).

Taking into account industry changes, structural and economic constraints reviewed here, what has been the result of the Maynard's efforts? Both, after having worked for separate "majority media" outlets, in 1983 became owners of a major communication outlet--the Oakland Tribune. The impact of their efforts will be more fully explored in the chapters to follow. 


\section{Chapter 3}

Method

This case study combined a method of historical inquiry and a method of content analysis. The historical method allowed organizational and industrial levels of analysis. The content analysis allowed a media level of analysis.

\section{Historical Analysis}

The history portion of this thesis was based on past literature and information from 24 interviews with former or current Oakland Tribune employees who were asked a standard set of 13 questions in addition to individual questions. The set of standard core questions is presented in List 1 on pp. 46-47. In addition to the standard interview questions, interviewees were asked separate supplemental questions based on their jobs, responsibilities, and the length of time they worked at the Oakland Tribune. The interviewees either worked during the Maynard ownership period or worked during the ANG ownership period. More than half of the interview participants had worked during both ownership periods. Interviews lasted from 45 minutes to two hours. All but two interviews were tape recorded; one source asked to be interviewed off the record, the other source did not feel comfortable with being recorded. The majority of the interviews were conducted in person. Six interviews were conducted by phone because (a) the interviewees said that they were very busy, and a phone interview was more expedient; or (b) they were no longer residing in the local area. 
The interviews represented a significant aspect of this study because they gave a deeper understanding of the many issues that affected the Tribune under Maynard and ANG. Combined with the historical approach, the information presented a context for the series of events that led up to the final outcomes presented by this study.

Three out of 27 interview requests were denied, and several participants were initially reluctant to be interviewed. Although partially speculative, the reluctance of these individuals to participate in this study was attributed to: (a) the fact that business knowledge is usually not publicly shared for competitive reasons, (b) the fear that information critical of the Maynards could be interpreted as racially negative, or (c) the fact that Maynard who is now deceased could not defend against criticism of past business decisions. Whatever reasons people had for not participating, their absences left holes in this study.

The final editorial product of a newspaper is not the sole province of editors and reporters. At most newspapers today, the marketing, advertising, and circulation managers directly or indirectly influence a newspaper's editorial outcomes. Interviewees were heavily represented by the editorial side of the Tribune. Although newsroom staff were aware of the circulation drives, the implementation of new marketing plans, and the efforts to obtain new retail advertisers, only a handful were involved in the actual strategizing. With greater access to key marketing, advertising, and circulation decision-makers, this case study could have been made more complete. 
This Oakland Tribune history was told by a few insiders. It proved impossible to tell the complete story, for there were many individuals who were not available or willing to lend their voices. Moreover, this study did not include the views of many outsiders who had a stake in the outcome--the readers, the advertisers, and the local community--their inclusion would have meant extending the study beyond the time limit set for completion. For all these reasons, this story was limited in what it could say.

Below are Lists 1 and 2. List 1 presented the set of standard core questions asked. Following List 1 is List 2 which presented the study's participants and persons who declined to be interviewed.

\section{List 1: Standard Interview Questions}

1. How did you get started in journalism?

2. When did you start working at the Oakland Tribune?

3. Tell me the position(s) you worked while at the Tribune?

3a. What were your responsibilities as (position)?

4. Tell me about the Tribune Tower. What was it like working there?

5. What about the equipment in the Tribune Tower, what was it like?

6. Did the state of the equipment affect your work?

7. What happened when ANG purchased the Oakland Tribune?

8. Did your job change?

9. Is the Tribune different under ANG? How? list continues 
10. What do you think of the ANG Oakland Tribune?

11. Did you personally work with Robert Maynard?

(If yes, then 11a.) Did you work with Maynard regularly? What was that like?

12. What can you tell me about Maynard's approach to journalism?

13. What was Maynard's editorial vision for the Oakland Tribune?

"Some interviewees were asked separate supplemental questions based on their jobs, responsibilities, and the length of time they worked at the Oakland Tribune.

List 2: Study Participants and Individuals Declining to be Interviewed

Interviewee, Interview Date, Position ${ }^{*}$

1. Leroy Aarons, 7/16/94, former executive editor and senior vice president

2. David Burgin, 9/12/94, ANG editor-in-chief and senior vice president

3. William Brand ${ }^{\mathrm{a}}, 3 / 31 / 94$, Berkeley bureau reporter

4. Mary Ellen Butler ${ }^{a}, 6 / 23 / 94$, former editorial page editor

5. Michael Collier ${ }^{\mathrm{a}}, 5 / 12 / 94$, former assistant city editor

6. Jacqueline Cutler ${ }^{2}, 3 / 29 / 94$, former education reporter

7. Benny Evangelistaa $4 / 19 / 94$, business reporter

8. Kevin Fagan, 6/2/94, former general assignment reporter

9. Paul Grabowicza, $5 / 5 / 94$, investigative reporter

10. Roy Grimm, 6/14/94, retired managing editor

11. Harry Harris ${ }^{\mathrm{a}}, 6 / 2 / 94$, police reporter

12. Steven Lavoie ${ }^{a}, 6 / 30 / 94$, director of libraries

list continues 
13. David K. $\mathrm{Li}^{\mathrm{a}}, 3 / 8 / 94$, general assignment reporter

14. Eric Newton, $4 / 16 / 94$, former managing editor

15. Lester $\mathrm{On}^{2}, 3 / 10 / 94$, retired slotperson

16. John Raess, 7/9/94, former deputy managing editor

17. Tim Schreiner, $11 / 25 / 94$, editor

18. Dean Singleton, 11/14/94, ANG owner

19. Craig Staats ${ }^{a}, 5 / 5 / 94$, political reporter

20. Pearl Stewart ${ }^{\mathrm{a}}, 11 / 12 / 94$, former editor

21. David Tong ${ }^{a}, 5 / 17 / 94$, business editor

22. Fred Wetton, $12 / 1 / 94$, retired director of advertising and sales

23. Johnny Wong, 5/15/94, former distribution and delivery person

24. William Wong ${ }^{a}, 6 / 16 / 94$, general columnist

anterviewee who worked under both ownership periods.

Individuals Declining to be Interviewed, Position*, Reason(s) for Declining

1. Kate Coleman, former marketing director: "No time."

2. Joe Haraburda ${ }^{b}$, ANG associate publisher, as stated by his assistant Elaine: Joe doesn't feel comfortable talking because he was formerly the general manager under Maynard and is now ANG associate publisher. Having been on both sides of the fence, he feels that there may be a conflict of interest.

3. Nancy Hicks Maynard, former deputy publisher: "No time" was the main reason given. At the author's second request by phone, Maynard stated, "I've looked at the 
list of participants and feel comfortable that you've done a broad and reasonable amount of research for the study that you've set out to do."

'Positions listed were those held at the time of interview, or if interviewee was no longer employed at the Oakland Tribune, position listed was that last held.

'Interviewee who worked under both ownership periods.

\section{Content Analysis}

In addition to allowing an historical analysis of the period being studied, interviewees' answers helped define what Maynard's editorial vision was for the Oakland Tribune. Information collected from the interviewees provided the basis for selecting (a) diversity and (b) total community coverage as issues of primary importance to Maynard. These two issues were examined in the pages of the Maynard and ANG Oakland Tribune as part of the content analysis.

Although Maynard may have had different visions or had visions that changed over time, the issues of diversity and community coverage were enduring elements of his broader vision. Before coming to the Tribune, Maynard was already nationally known among journalists for his diversity advocacy.

For Maynard, the issue of covering all segments of a community was not a new issue, it took center stage beginning with the 1960 s civil rights disturbances cropping up across the nation. At that time, from 1968 to 1977, Maynard was at the Washington Post, where he served as national correspondent, ombudsman, and editorial writer. 
Arriving at the Oakland Tribune years later, he instilled the importance of total community coverage in his news staff.

Whether an owner's vision could be transferred onto the pages of a newspaper was an issue that was explored by the content analysis and the historical portion of this thesis. The content analysis provided a media level analysis in addition to the organizational level historical analysis that was also based on interviews. It was hoped that, in combination, both analyses would shed greater light on past events and newspaper performance.

The issues of diversity and community coverage were examined separately by this content analysis. The overall objective of the content analysis was to identify patterns of (a) geographic emphasis according to devised geographic categories, and (b) news selection according to standard news and feature categories. The end goal was to see if there were changes in terms of news focus and geography, answering the questions: (a) what trends in news coverage can be observed between the two ownership periods studied? and (b) which geographic areas received coverage, and did those areas change between ownership periods? These questions were raised in a broader effort to address the issue of whether the Maynard Tribune was able to carry out its vision of total community coverage.

How each issue was measured is separately explained below. The limitations encountered in attempting to measure each issue within the pages of the Oakland Tribune were also discussed. 


\section{Diversity Categories}

The measure of diversity provided an indication of each owner's policy and commitment toward diversifying the newsroom. Variables that impact a writer's perspective are, but not limited to, cultural background, race, age, gender, and sexual orientation. This particular analysis examined the race and gender of (a) local Tribune columnists and (b) staff reporters whose bylines were identified as "staff writer."

The objective of this section was to determine the levels of diversity among local columnists and staff writers during each ownership period by an examination of entire issues of the newspaper. It tried to answer the question: Has the change in ownership changed the level of diversity among staff writers and local columnists?

It was decided that the most accessible means of obtaining a numerical breakdown of columnists and reporters by race and gender was to identify them by their bylines. Entire issues of the newspaper were searched for bylines and local columnists. Those reporters who had bylines identified as "staff writer" were listed on tally sheets for later identification. Those columnists identified as columnists for the Tribune were listed on separate tally sheets for later identification. The help of Tribune individuals was enlisted when later identifying the race and gender of reporters and columnists that were listed on the tally sheets.

It is important to point out that under the ANG integrated organizational model, some staff writers counted may not have been specific to the Oakland Tribune but were staff writers for any of the other four ANG newspapers. In addition, a few of the 
bylines counted may have been bylines not of staff writers but interns. This is not a significant issue since both owners made use of interns, and the inclusion of interns in the diversity count was made for both periods.

One of the drawbacks of looking only at bylines was that this study could not account for non-news staff or editors, but that was not the intent of this analysis. As discussed in the introduction, in a community such as Oakland, it was important to have individual reporters that the community could identify with. It was important to have reporters that were sensitive to racial, cultural, and gender differences in the community. The intent of this study was to count those individuals who were directly covering the community--the reporters.

This is not an argument supporting the notion that only women can adequately cover women's issues, or blacks best cover the black community. This may be true in some cases, particularly when the issue of language and access to sources is concerned, but it is not true in all cases.

\section{Total Community Coverage Categories}

Interviewees identified the concept of total community coverage as a broad goal that Maynard aspired toward as owner of the Tribune. The use of total community coverage as a measure for the content analysis presented the problem of defining community, a term that can have many meanings.

Community usually means a group of people who share particular values and beliefs, style of life, faith, or geographic boundaries. The most quantifiable definition 
was the one based on geographic boundaries, usually a neighborhood or a city. It was the definition this study used in its content analysis to measure the Tribune's community coverage.

The measure of total community coverage provided information about each ownership's editorial priorities in terms of which geographic communities were covered.

The significance of examining local coverage was explained by media critic Ben Bagdikian who argued:

No national paper or broadcast station can report adequately the issues and candidates in every one of the 65,000 local voting districts. Only locally based journalism can do it, and if it does not, voters become captives of the only alternative information, paid political propaganda, or no information at all (1992, p. 175).

Bagdikian also asserted that the trend away from independent newspapers with local ownership to chain newspapers with out-of-state ownership seriously diminishes society's democratic foundation. "We live in a dynamic world where ignorance of economic and political change is destructive of democracy and fatal to intelligent decision making" (1983, p. xiv).

In the case of the Tribune, the goal was to find if community coverage, as defined by geography, changed with the ownership transition from Maynard to ANG. 
In devising the geographic categories, the Tribune's metropolitan core and secondary geographic audiences were first determined in the interviews. The metropolitan core cities identified by interviewees were categorized by neighborhood. The secondary audiences of Alameda and Contra Costa Counties identified by interviewees were categorized into cities. This was done using the 1991 UpClose San Francisco Bay Area "Community Location Guide," which provided neighborhood breakdowns of local communities and city breakdowns of counties.

Once the geographic categories were established, stories from the front and local sections Were first classified as local or nonlocal. A story that took place in any one of the ten Bay Area Counties (Alameda, Contra Costa, Marin, Napa, San Francisco, San Mateo, Santa Clara, Santa Cruz, Solano, and Sonoma) was defined as local. The nonlocal stories were discarded. The local news and feature items were sorted into more specific geographic categories of Oakland, Berkeley, Piedmont, or Alameda or Contra Costa County cities. The remaining local items were placed in an "other" category. The geographic categories are presented below in List 3 .

\section{List 3: Geographic Categories}

Oakland Neighborhood News

News occurring in or relating specifically to local neighborhoods in Oakland: Claremont/Rockridge, East Oakland, Eastmont, Elmhurst/Brookfield, Forest Park, Fruitvale, Lake Merritt/Downtown, Lakeshore/Trestle Glen, Melrose/Seminary, Millsmont, Montclair/Piedmont Pines, Oak Knoll/Sheffield Village, Oakmore/Dimond, Temescal, and West Oakland. 
Berkeley Neighborhood News

News occurring in or relating specifically to local neighborhoods in Berkeley, North Berkeley, South Berkeley, and West Berkeley.

Alameda County Local News

News occurring in or relating specifically to any of the following cities: Alameda, Albany, Castro Valley, Dublin, Emeryville, Fremont, Hayward, Livermore, Newark, Pleasanton, San Leandro, and San Lorenzo

Contra Costa County Local News

News occurring in or relating specifically to any of the following cities: Antioch, Brentwood, Clayton, Concord, Danville, El Cerrito, Hercules. Lafayette, Martinez, Moraga, Orinda, Pinole, Pittsburg, Pleasant Hill, San Pablo, San Ramon, and Walnut Creek.

\section{Miscellaneous Local News}

All other cities that are located in the remaining Bay Area counties (Marin, Napa, San Francisco, San Mateo, Santa Clara, Santa Cruz, Solano, and Sonoma) but which do not fall into any of the above categories.

News Type Categories

The 25 news and feature categories used to classify the type of news emphasized by each ownership were based on a 1977 study by Denis McQuail for the British Royal Commission. The broad aim of that study was to "provide some evidence relevant to the question of editorial standards in newspapers in the U.K." (p. 1).

Although the categories were originally used to study U.K. newspapers, they had a general applicability that made them usable for U.S. newspapers. In his discussion of the categories used for his study, McQuail wrote that the categories were "relevant to the purpose of the description and meaningful to those familiar with the press," (p. 1). He further argued, "[W]e assume that the categories are equally 
applicable to different sorts of newspapers" (p. 1). The decision to use these categories was based on their general applicability. The general nature of the categories made them easily (a) transferable, (b) extended, or (c) narrowed for this study of the Oakland Tribune.

Some modifications, extensions, and additions were necessary to the original coding frame because this study was concerned with diversity and local political issues that were not issues in the original study.

The nature of news is such that no classification scheme can result in absolute mutually exclusive categories. If a story fit in more than one category, the item was placed in the category that best reflected the main subject of the story. Those items that did not fit in any category were placed in an "other" category. The placement of items in the "other" category amounted to $0.03 \%$ of the total items analyzed. The 25 news type categories are listed below in List 4.

\section{List 4: News Type Categories}

News

\subsection{POLITICAL}

Matters concerning local politics and local government, where the main focus is on parties, politicians, elections, party organization, inter-party relations, political appeals to public, vice versa. Includes state court decisions with local impact.

1.1N. National Politics Locally, including news and views of local Congressional representatives, and their doings in Congress. Includes federal court decisions with local impact. 
1.12. ECONOMIC

Industrial or financial news relating to locality or region of paper; local employment matters; new developments and closures; productions and orders; land, property, and tax matters. Includes local labor and union; market and price news.

\subsection{SOCIAL SERVICES}

News of local social services where the substance of a story concerns the service provided and the public, rather than administrative, political, business, or financial aspects. Social welfare and social work; local public transport where the issue is social, not financial; the major social services of health, housing, education, and recreation. Also news concerning public industries where service to public is involved.

\subsection{Voluntary Social Service Activity}

This includes events, fundraising, and meetings. This category is mainly confined to organizations concerned with social welfare (health, children, elderly, homeless, disabled, etc). Some of this activity will be carried out by nonprofits, charitable, and religious organizations.

\subsection{P. Local Social Problems}

News relating to social problems. Examples might include stories of juvenile delinquency in particular areas, elderly alone, poorly equipped hospitals, homeless, etc.

\subsection{PLANNING, ENVIRONMENT, AND TRAFFIC}

Reports on local planning and development, local protests. Road and traffic schemes and problems. Structure plans. Housing where development has environmental implications. Pollution, threats to or improvement of local amenities. Loss of shopping or other commercial facilities.

\subsection{ISSUE OF RACE, CULTURE, MULTICULTURALISM, IMMIGRANTS}

Includes political, economic, and social service matters to do with race and community relations. News relating to economic, political, or social issues of minority communities/groups. Any other issues or matters pertaining to race, activism, and/or problems, etc. Diversity issues.

\subsection{CRIME AND POLICE}

News from local courts and police, reports of crimes, vandalism, etc; police administrative news. Includes local trial coverage. 


\subsection{ACCIDENTS}

News of accidents, missing persons, fires and damage, natural disasters, sudden deaths, injuries. Includes accidents to animals.

\subsection{PERSONALITIES}

Local people in the news. Social events where guests provide main news interest. News of deaths, marriages, engagements, travel, appointments, exam results, prizes and awards. National celebrities in the local news.

\subsection{LOCAL SPORT}

Local sport news

\subsection{EVENTS AND ACTIVITIES}

News of, and reports from, local events where the event rather than the participants provide the main focus of the news; this includes meetings and activities of local clubs and societies, festivals, concerts, drama, fairs and sales, church services, competitions, dances, fund-raising, community council, and association meetings.

\subsection{INFORMATION}

Notices of local events and other specific local information, like weather conditions, road closures, church services, etc.

\subsection{OTHER LOCAL NEWS}

\subsection{GENERAL INTEREST ITEMS}

\section{$\underline{\text { Features }}$}

\subsection{POLITICAL, SOCIAL, OR ECONOMIC}

Features dealing with the subjects mainly covered under categories $1.1,1.1 \mathrm{~N}, 1.12$, $1.13,1.13 \mathrm{~V}, 1.13 \mathrm{P}, 1.14,1.2$.

\subsection{ISSUE OF RACE, CULTURE, MULTICULTURALISM, IMMIGRANTS} Features dealing with matters of race and community relations and covered under categories $1.1,1.1 \mathrm{~N}, 1.12,1.13,1.13 \mathrm{~V}, 1.13 \mathrm{P}, 1.14,1.2$. Features news relating to economic, political, or social issues of minority communities/groups. Any other issues or matters pertaining to race, activism, and/or problems, etc. Diversity issues. 


\subsection{LOCAL TOPOGRAPHICAL AND LEISURE}

Features about places to visit, things to do, local life and amenities, environment, and things of interest. Includes nature notes, local history, and archaeology; extracts from the paper in the past (50 years ago).

\subsection{CONSUMER/PRICES}

Advice to shoppers and other matters of consumer interest relating to shops, services, and housing, etc. (excludes advertising).

\subsection{PERSONALITIES AND ASSOCIATIONS}

Features about local people, including local gossip or "social life" columns. Also includes features on local clubs and associations.

\subsection{SPORT}

Local sport features.

\subsection{ARTS, ENTERTAINMENT, REVIEWS}

Books, theater, music, fashion reviews.

\subsection{HOME FEATURES}

Includes home improvement, cooking, family-related features.

\subsection{OTHER FEATURES}

\section{Definition of Items}

For both measures of geography and news type, only staff-generated stories that were longer than five paragraphs from the front and local sections of the Oakland Tribune were systematically categorized. For a story to qualify as a staff-generated item, it had to (a) be attributed to a staff writer of the newspaper, or (b) have a local dateline, and (c) be non-wire or non-syndicated copy.

Once an item qualified to be counted, its length was determined by a paragraph count. A news or feature story that was shorter than five paragraphs was defined as a news bulletin or filler and was not counted as an item. They included, but were not 
limited to, sets of brief announcements that included world and Bay Area news, crime briefs, calendar-type events, and news snippets. Items such as paid legal announcements, birth and wedding announcements, obituaries, comics, photos, and advertisements were not included as part of the analysis because they were not relevant to the questions to be answered here.

When assigning items to a news type or geographic category, the lead paragraph and the following four paragraphs were read, rather than whole-item analysis. It was determined that this would be the most efficient use of economic and time resources. This decision was based on the assumption that the journalistic convention of the inverted pyramid was in use by Tribune journalists. With the inverted pyramid, the summary of the story could usually be derived from the first five paragraphs which included the lead and the "nut graf" (which usually contains the main point of the story).

If the main subject or geographic location of the item could not be determined from reading the first five paragraphs, then the author or coder read the whole item in order to determine which news type or geographic category the item should be classified under.

Sample Selection

The periods purposively selected for examination in the content analysis were ownership periods under Maynard (April 30, 1983, to November 30, 1992) and the 
present owner, the Alameda Newspaper Group (December 1, 1992, to December 31, 1994).

Original issues of the Oakland Tribune from March 27, 1994, to December 31, 1994, were collected by private subscription. Issues before March 27, 1994, were available on microfilm and were analyzed at the Newspaper and Microfilm room at the University of California at Berkeley.

This content analysis examined 56 issues of the Oakland Tribune, for a total of eight weeks worth of news coverage. The study examined four years of coverage, allocating 14 issues per year. The years chosen for examination were 1984-85, 1987 $88,1990-91$, and 1994 . The years were purposively chosen to capture the beginning, middle and end of the nine-year Maynard period. Maynard became owner of the Tribune on May 1, 1983. For this reason, the Maynard years of this study began on May 1st and ended on April 30th. For ANG, the calendar year 1994 was chosen because it was the latest whole year that fit within the time frame of this study.

For both Maynard and ANG, the first year of ownership was excluded because of possible irregularities in news coverage resulting from the ownership transition. Irregularities in news coverage may have resulted from changes in management and reporters and the consolidation or creation of beats. The occurrence of the Oakland/Berkeley hills fire in October 1991 might have caused some irregularities in news coverage. However, the month of October was not selected in the random construction of weeks for the year 1990-91. 
Although the years were purposively chosen, the two-week periods of each year were randomly constructed. The procedure for selection was as follows. Two days of each weekday, Sunday through Saturday were randomly selected. The weeks of each year were assigned numbers from 1 through 52 (for Maynard years, week 1 began with May 1st; for ANG years, week 1 began with Jan. 1). The numbers 1-52 determined the week in which a particular weekday was chosen. For example, in selecting Sundays to construct the two-week period, two numbers between 1-52 would be randomly selected. If the numbers selected were eight and thirty-four, then the Sundays falling on the 8th and 34th week for that calendar year would become part of the sample. The numbers 8 and 34 would be returned to the group 1-52, and the selection would continue for Mondays, Tuesdays, and so forth, until two complete weeks were constructed for all four years examined.

The dates selected were as follows:

1985: $5 / 21,5 / 22,6 / 7,6 / 10,7 / 4,7 / 23,7 / 25,10 / 9,10 / 13,12 / 15,12 / 27$.

1986: $1 / 20,4 / 12,4 / 26$.

$1987: 6 / 4,7 / 14,8 / 26,9 / 24,11 / 22,12 / 7,12 / 16,12 / 25$.

1988: $1 / 3,2 / 12,2 / 20,3 / 21,4 / 12,4 / 30$.

1990: 5/27, 6/14, 6/15, 6/21, 8/4, 8/28, 10/17, 11/11, 12/28.

1991: $1 / 14,1 / 23,3 / 4,3 / 30,4 / 2$.

1994: $2 / 7,2 / 23,3 / 4,3 / 8,3 / 24,3 / 27,7 / 16,7 / 21,8 / 1,8 / 7,9 / 17,9 / 28,12 / 2,12 / 27$. 
A pretest was carried out by the author and another mass communications graduate student to determine the applicability of the 25 news type categories. Analysis sheets were used for data collection. The pretest was carried out using six issues of the Oakland Tribune with dates of publication outside of the selected sample. A figure of six issues was used because it constituted $10 \%$ of the sample to be analyzed.

Categories that were initially too broad were narrowed. Categories were added when a significant number of items could not be placed.

In the pretest, all local stories from the front and local sections were placed in geographic and news type categories. All staff writer byline names and local columnist's names from the entire newspaper were listed on tally sheets. In the actual diversity count, these names would have later been identified by race and gender.

The assistant coder was encouraged to consult with the author as much as necessary so as to increase intercoder agreement. The average reliability for the listing of Oakland Tribune staff and columnists for later gender and racial identification was $96 \%$. The average reliability for identifying the geographic location of an item was $89 \%$. The average reliability for identifying the news type category of an item was $77 \%$. The intercoder reliability test results are presented on the following page in Table 1. 
Table 1

Intercoder Reliability Test Results

\begin{tabular}{lccl}
\hline Issue date & $\begin{array}{c}\text { Diversity } \\
\text { listing }\end{array}$ & $\begin{array}{c}\text { Geographic } \\
\text { location }\end{array}$ & $\begin{array}{l}\text { News } \\
\text { Type }\end{array}$ \\
\hline $10 / 4 / 94$ & .96 & 1.00 & .80 \\
$12 / 23 / 94$ & .93 & 1.00 & .75 \\
$12 / 21 / 94$ & 1.00 & .85 & .77 \\
$8 / 11 / 94$ & .93 & .76 & .65 \\
$6 / 15 / 94$ & .96 & .93 & .87 \\
$3 / 23 / 94$ & .95 & .81 & .79 \\
\hline Average reliability & .96 & .89 & .77 \\
\hline
\end{tabular}




\section{Chapter 4}

The Maynard Tribune

This chapter was an historical analysis of the Maynard Tribune. The first portion of this chapter attempted to define the basic components of Maynard's editorial vision for the Oakland Tribune, derived mainly from the perceptions and comments of his staff in interviews but also from the literature review.

The remainder of this chapter traced that vision by looking at the Tribune, in terms of editorial and geographic focus, as different business plans were implemented and revamped to meet the economic needs of the paper. On pp. 68-70, a time line tracing the significant events of the Maynard era up until the ANG purchase of the Oakland Tribune is presented as part of the historical analysis.

Maynard's Editorial Vision

It was assumed that over the nine-year period of ownership that Maynard explicitly and informally imparted his personal philosophies and his vision for the Tribune to his editorial staff directly or through his top editors. This assumption was verified through the responses of many of the interviewees who regarded Maynard as an advocate for diversity and total community coverage, the two issues that were most frequent answers to the question: What was Maynard's editorial vision for the Oakland Tribune?

Mary Ellen Butler, former editorial page editor, summed up what Maynard represented to many of the Tribune staff. She said, "Maynard brought a vision [to the 
Tribune]. That was to broaden journalism in terms of staffing and coverage. To include the whole community" (recorded interview, June 23, 1994).

Philosophically, covering the whole community was meant to lead to a sharing and therefore better understanding among all peoples within the community. Maynard called such an ideal, an "instrument of community understanding," said Leroy Aarons, former executive editor and senior vice president:

Editorially, Bob believed that a newspaper should be an instrument of community understanding. What he brought to the Oakland Tribune was his lifetime philosophy that a newspaper should reflect, and give back to, its own community--and that means all of it. His goal was, to every degree possible, to have every aspect of Oakland and its surrounding region reflect people of color, whites, all socioeconomic levels (recorded interview, July 16, 1994).

In concept, an instrument of community understanding would enable a community to respond to the important issues facing it. A community can do this only if its newspaper accurately reflects what is going on within the community. Davison (1982) wrote:

One can argue that news and the mass media in general are misleading. They ignore vast areas of social reality while highlighting others. The picture they present is not a reflection of reality. They create a pseudo-environment (to use Walter Lippmann's term) that makes it more difficult for people to respond to their problems (p. 113). 
Retired Managing Editor Roy Grimm talked of how Maynard helped him better understand the concept of total community coverage:

Bob was passionate about covering the total community. Not just the longestablished interest groups, but all the people of the community. I think this is important because while they may not have subscribed, maybe not even patronized the advertisers--I'm speaking of the large immigrant population, primarily Southeast Asians but also Hispanics--nevertheless . . they as people [needed] to be covered as part of [the paper's] service to the community. Right here, it is not possible to cover a city and ignore a whole chunk of the population that's here just because they don't speak English or just because they're black or yellow or whatever. That is not economically good sense, but worse than that, it is not socially good sense. Bob Maynard believed in covering the whole community and while I'd like to think I thought that before he arrived, under him I gained a much greater understanding and a deeper belief (recorded interview, June 14, 1994).

Implicit to achieving the goal of being an instrument of community understanding was the requirement that those chosen to educate, define, and interpret for the community through their reporting, be familiar with, have knowledge of, and have a connection to the community they are covering. In this manner, the idea of an instrument of community understanding and newsroom diversity was inextricably linked. In a 
heterogeneous city such as Oakland, it became necessary to have a diverse staff of reporters.

Even before Maynard came to the Tribune, he was an advocate for diversity. It was Robert and Nancy Hicks Maynard's efforts along with other advocates for greater diversity in American daily newspapers that led to the adoption of a goal by the American Society of Newspaper Editors to have the nation's minority newsroom populations equal to the percentage of minorities in the general U.S. population by the year 2000 (Wilson \& Gutierrez, 1985).

David Tong, former and current Oakland Tribune business editor, and a graduate of the Michelle Clark Program for Minority Journalists at Columbia University, said, "As a mentor and a friend, [Maynard] had high ambitions to diversify newsrooms across America and he used [the Oakland Tribune] as a vehicle" (recorded interview, May 17, 1994).

Interviewees provided a firm grasp of what Maynard represented, and what he wanted for the Oakland Tribune. The issue of total community coverage, however, presented this study with the problem of defining community for the purpose of the content analysis.

Communities are made up of groups of people who share values and beliefs, styles of life, faiths, or geographic boundaries. The most accessible definition was the one based on geographic boundaries, usually a neighborhood or a city. It was the 
definition this study used in its content analysis to measure the Tribune's community coverage, the findings of which are presented in chapter seven.

\section{The Maynard Tribune: A History}

With the aid of the eyes and ears of the editorial and business staff, this thesis traced the different forms that the Oakland Tribune took on as definitions of community were recreated to meet the needs and constraints of the local marketplace. The period is reconstructed by building on accounts of those who experienced it and were willing to discuss it. The Maynard period is important primarily because of the people involved in the events and the many "firsts" achieved.

These accounts amounted to four periods that were manifestations of Maynard's editorial vision. They were (a) "the Intelligent Alternative," (b) the Suburban March, (c) the Ruth Clark survey, and (d) the "Urban Eastshore." These four periods were chosen based on literature and interviewee information. An Oakland Tribune time line of the significant events surrounding these four periods is presented below in Figure 1.

Figure 1: An Oakland Tribune Time Line from Maynard to ANG

1976 Maynard co-founds the Institute for Journalism Education at the University of California at Berkeley.

1977 The Knowland family sells the Oakland Tribune to Phoenix-based Combined Communications.

Combined strikes "Oakland" from the newspaper's title.

1979 Gannett acquires the Tribune as part of a larger acquisition deal with Combined Communications. 
1979 Gannett returns "Oakland" to the newspaper's title.

November--Eastbay TODAY launched.

Maynard is appointed editor of the Oakland Tribune under Gannett.

1981 Maynard is appointed publisher of the Oakland Tribune under Gannett.

1982 September 25--Eastbay TODAY ceases publication and the afternoon Oakland Tribune is converted to a morning publication.

"Oakland" is removed from the newspaper's title.

1983 April 30--It is announced that Maynard has purchased the Tribune from Gannett for $\$ 22.5$ million in a leveraged buyout. $\$ 17$ of the $\$ 22.5$ million from Gannett.

1985 July--Dean Singleton purchases the Hayward Daily Review, the Fremont Argus, and Tri-Valley Herald newspapers from Floyd Sparks.

1986 Consultant Ruth Clark hired to conduct a readership survey for the Tribune.

1987 Maynard first diagnosed with prostate cancer, undergoes radiation therapy.

1989 October 17--Northern California Loma Prieta earthquake.

1990 The Tribune wins the Pulitzer Prize for photojournalism coverage of the Loma Prieta earthquake.

Durkee/Sharlitt Associates, turnaround specialists, hired by the Tribune.

1991 February 26--The "Urban Eastshore" plan launched. "Oakland" is returned to the Tribune's title.

August 8--Maynard announces that he will be forced to close the Tribune's doors if no resolution occurs in the renegotiation of Gannett's $\$ 31.5$ million note.

time line continues 
1991 August 14--Allen H. Neuharth, chairman for the nonprofit Freedom Forum (formerly Gannett Foundation), announces the advancement of several hundred thousand dollars for the Tribune's current operating needs and an agreement to settle the Gannett debt.

October 20--Oakland/Berkeley hills fire

Maynard's cancer recurs

Freedom Forum transaction that converted most of Gannett's $\$ 31.5$ million note to $\$ 5.5$ million in equity and $\$ 2.5$ million in interest-free debt is completed.

October 15--It is announced that the Oakland Tribune has been sold to Dean Singleton's Alameda Newspaper Group for a sum reported to be close to $\$ 10$ million. ANG agrees to pay the newspaper a total of about $\$ 17.5$ million over the years after 1992 for the newspaper's name and subscription list.

August 17--Maynard dies

Production and printing of the Oakland Tribune moved out to a satellite plant in Pleasanton.

For many of the individuals interviewed, the Maynard years were tough yet inspiring and rewarding. Under Maynard, many of the newsroom staff came to work at the Oakland Tribune because they had a connection to Oakland or to Maynard. Some grew up in Oakland. Many lived there or had relocated there and came to love the area. Others came because they knew Maynard. Some had worked with him at the Washington Post. For some, he had been a mentor at the Michelle Clark program at Columbia University or the Summer Program for Minority Journalists at Berkeley. 
Others were drawn to the Tribune because of Maynard's reputation. Kevin Fagan, former assistant news editor, Contra Costa bureau chief, and reporter, said of Maynard: People knew his history. He had a real history in the bisiness. He was not only a good journalist but he wanted to do big things. And the fact that he was the only African-American to own a paper that size--it was terribly exciting because you got to work for a guy that had some ethnic awareness to him. He wanted to be able to take this ethnically mixed, vibrant region and tap it for everything it was worth--journalistically (recorded interview, June 2, 1994). David $\mathrm{K} . \mathrm{Li}$, one of youngest reporters and last to be hired under Maynard in August 1992, said:

As a reporter, as a journalist, he was a real shining hope to people like me and other minority journalists growing up. I grew up in the ' 80 s, went to college in the '80s and I knew about Bob Maynard, and 'I thought damn,' maybe there's a chance. Maybe there's a chance we won't be frozen out by the establishment. I know it gave me hope. But more than that. You got a good product. And I think the people of Oakland got a good product. He wasn't just a black guy. He's a black guy that owned a newspaper and took on the establishment, including the black establishment in Oakland (recorded interview, March 8, 1994).

Many interviewees described Maynard as an "optimist." It was hard to tell him that he "could not do something." Those who worked with him personally described 
him as worldly and a quick thinker. A few people described him as brash, aggressive, and not particularly approachable. One reporter said that Maynard had an arrogant streak to him--that he wouldn't listen.

John Raess, former assistant city news editor and deputy managing editor, said of Maynard, "Bob was one of Oakland's treasures. One of the city treasures. Apart from the Tribune, Bob was kind of an entity and a community institution unto himself. People would see him on national TV all the time. He would often be called in on matters of race. A 'Nightline' or [David] Brinkley would call him" (recorded interview, July 9, 1994).

Roy Grimm, retired managing editor, who worked at the Tribune under the Knowlands through Maynard, said:

Don't let anyone tell you he was an inspiration only to aspiring minority journalists, although that's what he's generally credited with. He was an inspiration to journalists of all colors and those of us who were white--in particular the young ones. I'm not saying I learned a lot from him, but the young ones--he encouraged journalistic talent--and he gave a lot of young people a chance. And it wasn't on the basis of race, even though he did more sooner and more than anyone has since, to attract, train, and help minorities, through the Institute for Journalism Education (recorded interview, June 14, 1994). 
In a city where the major political players were black, the racial card was often played when the Tribune ran stories critical of local government. Black government officials that received negative coverage felt betrayed by Maynard because he was black. Reporters respected Maynard because he did not back down when faced with the outcry and criticism from the black establishment. One reporter who asked not to be identified said he was doing an investigative story on a friend of Maynard's. Maynard took him aside one day and said, 'Well, you probably know that I'm an acquaintance--do what you need to do.' In the reporter's words, [that friend] "got hammered" (personal communication, June 2, 1994).

Maynard was brought in as the Oakland Tribune's new editor under the Gannett Company chain in 1979. In 1981, he would be named publisher. At the time of his appointment to editor, Maynard had been working as an affirmative action consultant for Gannett, after having left the Washington Post in 1977. Maynard's arrival changed the paper's staffing and outlook. Grimm said:

When Maynard came in, he brought in this young talent. . . . It was important that be done in Oakland because the demographics of the city had changed steadily in the ' 70 s. But he also brought in outside, mid-level managers and talent who had learned elsewhere, who had worked with major organizations, who had more interaction across the country, who had different ideas. The Tribune had a history of being very inbred. The top managers, by and large, got there by surviving along, just living a long time and kind of floatin' to the 
top instead of rising to the top solely on talent. You know, I gotta indict myself there. I moved maybe a little faster than some of them but except for my three years in Hayward [at the Hayward Daily Review], I had no other experience. I'm not saying that working at 20 different newspapers is necessary, but in the total mix of the news staff you need people who have worked for different news organizations. Different editors have different perspectives, so that you have some fresh ideas. The Tribune was so inbred, it almost genetically malfunctioned. On editorial ideas, if you will, Maynard stirred all that up, brought freshness, vitality (recorded interview, June 14, 1994).

\section{"The Intelligent Alternative"}

Under Gannett, the Tribune published two newspapers, Eastbay TODAY (EBT) and the afternoon Tribune. On September 25, 1982, the Tribune reported that Gannett was discussing the possibility of selling the Tribune to its current publisher and editor, Maynard. A little less than a month later, on October 23, 1982, Gannett stopped publishing EBT. Publicly, there was trace left of the morning publication.

By then, Gannett was publishing USA TODAY and did not want the Tribune using the name "TODAY," according to Fred Wetton, vice president of advertising and business development. Wetton said of EBT:

The unfortunate thing about it was that when Gannett decided they were going to sell the Tribune, part of the condition of sale was to shut down EBT. Well, this caused a lot of confusion. It cut our circulation down considerably, just 
overnight. Bob wasn't even allowed to use the name, because by this time, Gannett knew they were going to launch a national product with the name TODAY in it, and they did not want any papers using that name (recorded interview, December 1, 1994).

Of that period in Tribune history, Wetton said, "EBT was an exciting time. Gannett had the resources to market, distribute, and promote it."

By comparison, the Tribune after Gannett would have finite resources to market itself. However, its first effort would begin with the promotion of the new Tribune as "the Intelligent Alternative."

The afternoon Tribune was switched to mornings. Although still officially under Gannett ownership, "the Intelligent Alternative" was Maynard's attempt to directly compete with the San Francisco Chronicle for the readers within the Tribune's own core markets of Oakland, Berkeley, and Piedmont. In addition to the shift from afternoon to morning publication, there was a pullback from distribution in fringe areas that were formerly served by EBT. Promos heralding the change said, "Say good morning to a greater metropolitan newspaper," with a subhead of "the Intelligent Alternative" (Tribune, 1982, p. A-4).

On May 1, 1983, Maynard officially announced that he had purchased the paper. The Tribune's headline trumpeted, "New era at The Tribune." The subhead read, "Maynard buys the newspaper" (p. A-1). 
As owner, Maynard's roles and responsibilities changed, and so did his economic and personnel resource base. He now was responsible for the business side of the newspaper which directly impacted the newspaper's financial health and growth.

In the group of articles in the Oakland Tribune covering Maynard's succession to owner, Tribune Staff Writer Craig Staats wrote:

Maynard said he also welcomes the break with Gannett because he thinks it will be easier for him to refuse the multitude of invitations he received to speak to groups around the nation, as a visible part of Gannett. His absences became a sore point with some on the editorial staff, who felt that important decisions got postponed when he was gone (1983, p. A-12).

With Gannett obligations seemingly behind him, Maynard set out to attract readers from the Tribune's metropolitan core. Leroy Aarons, former executive editor and senior vice president, said:

When Bob first took over, initially, his goal was to recapture the Oakland and Berkeley audience. He had the belief that if there were a good newspaper that cared about its community, that wrote about its community, that was based on the home turf, that was run by a family who lived in Oakland, who cared about it--a kind of old-fashioned family ownership that was not run from a corporate headquarters somewhere else--it would get a response. He had the impression that the [San Francisco] Chronicle was a frivolous paper and that people 
wanted serious community journalism and also serious national and

international coverage (recorded interview, July 16, 1994).

According to Aarons, Maynard believed they could capture those Oakland, Berkeley, and Piedmont readers who had so far eluded them by doing good journalism--better than the San Francisco Chronicle. John Raess, former assistant city news editor and deputy managing editor, said, "[Maynard] wanted to challenge the Chronicle directly. What he wanted to do to challenge the Chronicle directly was--in fact these were his words that he used--to become "the Intelligent Alternative."

The look of the newspaper was changed. The Tribune was redesigned into a vertical, Wall Street Journal-type format. Maynard created a "Column One" which was to be a thoughtful, perspective story that was local or wire. These format changes were made in the belief that they would appeal to the socially conscious reader and that there was a market for good, serious journalism.

For the Tribune business department, the market's response to "the Intelligent Alternative" was very slow in coming or not coming at all. Aarons said, "It became fairly evident, fairly quickly, that it was not making a bump at all in the [San Francisco] Chronicle's domination of Berkeley . . . and large parts of the Bay Area."

William Brand, former and current Berkeley bureau reporter, said the one effect that "the Intelligent Alternative," plan had was to force the [San Francisco] Chronicle 
to beef up [its] East Bay coverage. He added:

There were a lot of people that really cared. . . Like in the business section, we used to work our balls off--everybody--and we worked hard and long and it was exhausting. And the Chronicle, we squeezed them. Then they just beefed up their sections and added more and more 'til it became a joke, and we couldn't keep up with them (recorded interview, March 31, 1994).

Eventually "the Intelligent Alternative" concept was shelved, and there came increasing pressure from the business side for the Tribune to refocus its efforts outside of Oakland, the Tribune's metropolitan core. The business department contended that Oakland was not an expanding market and that there was no future in just focusing on the city with its economic problems. The business department made forceful arguments supporting a move out into the adjacent suburbs of Contra Costa and southern Alameda Counties. (These areas had been abandoned by the Knowlands nearly two decades ago).

In their 1971 study of Bay Area newspapers, Rivers and Rubin wrote, "The motto of the Tribune is 'A Responsible Metropolitan Newspaper.' The overriding question for the paper in the next decade is: to whom must it be responsible?" (p. 51). Rivers and Rubin were studying the Knowland Tribune, but the question they raised was one that Maynard grappled with, time and time again, over the nine-year period of ownership. 
As an independent owner, Maynard's vision for the Tribune was battered by the larger economic constraints of the Oakland marketplace. According to multiple sources, Maynard's editorial mission of good, hard-hitting journalism remained firm during this period. Yet the need to produce a profitable paper would force a change of the Tribune's initial geographic focus on its core markets. In an effort to recover local advertising losses, the Tribune gambled on a move into suburban Contra Costa and southern Alameda Counties.

The Suburban March

The suburban march outward was aimed at on attracting readers to the Tribune in Contra Costa County and southern Alameda County. It was a direct challenge to newspaper owners Dean Lesher (in Contra Costa County) and Floyd Sparks (in southern Alameda County). Lesher, owner of the Contra Costa Times, was a formidable competitor, but the Tribune business staff reasoned that if the Tribune could make inroads, it would be worth the huge effort and financial risk.

In his analysis of Bay Area newspapers, entitled "Newspaper Wars," Rapaport (1989) wrote: "Contra Costa is the media plum of the Bay Area, a county already growing spectacularly and guaranteed to keep growing through the nineties and into the next century" (p. 96). Aarons said of the suburban push outward, "We had some penetration down south in Hayward and that area, but the advertiser's choice market was tantalizingly just over the hill in Contra Costa County" (recorded interview, july $16,1994)$. 
When Maynard became convinced that the Tribune could take a shot at Lesher's territory, he again believed that the Tribune could break off a piece of Lesher's empire by doing good journalism. Aarons said, "A huge investment was made on the theory that we could penetrate and begin to chip away in those areas."

Looking back on the Tribune move, and commenting on why Maynard may have decided to go out to Contra Costa, Raess said:

I think Bob began to realize, probably in the mid-' 80 s, that somehow if the Tribune was to survive, he had to get the advertising revenue up. And I think his vision evolved along with the needs of the newspaper. He tried hitting Contra Costa County real hard as a strongly zoned, local alternative for the Contra Costa Times. His vision was of a metro paper that zoned strongly. They tried to do the same thing in southern Alameda County. These things were never really a success. They managed to pump revenues up--I'm not sure how much, five million, ten million dollars a year--but the cost went up the same (recorded interview, July 9, 1994).

Of the move out to Contra Costa, Grimm said: "We were essentially giving away the Tribune, at least parts of the Tribune in Contra Costa County--a shopper." The giveaway was part of the larger circulation drive to reestablish Walnut Creek and Martinez bureaus.

Thus began the zoning of the Tribune for Contra Costa and southern Alameda Counties. It heated up the struggles between suburban and urban news coverage and 
between news and business staff. Aarons said, "Bob had gathered together a bunch of idealistic young journalists. There was a real us-and-them mentality, and that the business side was pushing the Tribune and dominating it."

According to several interviewees, the suburban effort had some success but the revenues were not rolling in quickly enough to meet the cost. Others surmised that the Tribune could have been successful if only they had had enough resources to maintain the effort over a longer period of time. Aarons said of the suburban effort:

There was a gradual and agonizing pullback--one that was only slowly accomplished and forced by the fact that the income base was getting smaller. The circulation base was not growing and there was also a hostility toward the effort in the newsroom which felt that we were diluting our impact, in that we were sacrificing the mission of serving the inner community and going out vainly to capture the white upper-middle class suburban audience (recorded interview, July 16, 1994).

As the Tribune expanded into the suburbs and then slowly withdrew from the suburbs, an outside consultant named Ruth Clark would be hired to do a readership survey. The survey results led the Tribune to refocus its efforts on the upscale portion of the paper's core markets in the Oakland and Berkeley hills. 


\section{Ruth Clark's Micronews}

The actual results of the Tribune study were not revealed to staff but Michael Collier, former Hayward bureau correspondent, general assignment reporter, and Sunday editor, said:

The management spin on the Ruth Clark survey was we gotta do more local stories--so what they did was they covered street fairs in Montclair. They did Montclarion-type stories, Hayward Review-type stories. [They] tried to sort of outlocal the little community papers and it was a disaster. [Piedmont and Montclair are two of the more affluent areas within the Oakland hilis. The Hayward Daily Review, currently owned by ANG, is a suburban daily in southern Alameda County.] (recorded interview, May 12, 1994).

By the late 1980 s, advertising revenues were down among newspapers, the result of a nationwide recession. At the Tribune, there was discontent brewing in the newsroom, a streamlining of the executive ranks, and Maynard was attempting to renegotiate the Gannett loan. In 1987, Maynard was diagnosed with prostate cancer. That same year, The Tribune experienced the first of two staff reductions. The second reduction occurred in June of 1990 , when staff was cut back by $25 \%$. The economic woes of the newspaper brought employees closer together and unified an increasingly militant newsroom. In early 1991 employees earning more than $\$ 25,000$ a year took a mandatory $11 \%$ pay cut. 
In a public speech to the Oakland-Metropolitan Forum, Maynard discussed the restructuring occurring at the Tribune. At one point, Maynard addressed the difficult issues of the $25 \%$ staff reduction and his health. In the big picture, Maynard's declining health was an issue that had considerable impact on the future of the Tribune, yet it remained obscured by the more public organizational and financial difficulties of the newspaper. He said:

Now you must know it gives me no pleasure to think of The Tribune losing a quarter of its employees. We are, after all, a family. We have been for some time. There is a profound dedication and loyalty that runs deep in our roots. No institution could reach 116 years old without developing some abiding traditions and no small amount of esprit de corps.

But I know through hard and trying personal experience that when you are ill, you either take the treatment that preserves life or you face the alternative. When cancer came calling at our home just three years ago, Nancy, the children and I were devastated by the news. Nancy and I went down to Stanford Medical Center that frightening day in June of 1987 . We met a wise and kind physician there, Dr. Foad Frieha. ... He confirmed what we already dreaded. I had cancer of the prostate. After spending hours with us, Dr. Frieha turned to Nancy and said, 'Mrs. Maynard, you husband is very ill. We can make him better, but first we must make him feel even more sick.' He was 
referring to the devastating side effects of radiation therapy. He was as good as his word on both counts (Tribune, 1990, p. B-7).

Maynard became less and less visible in the newsroom as time wore on. Aarons observed that although Maynard's relationship with the nonnewsroom employees remained warm, relations with the newsroom became more strained. He said: I think that there was a distancing--Bob and his newsroom employees--and [Maynard] showing up less and less. He used to take pleasure walking through the newsroom and talking to people. As things got tighter and more troublesome, there were more layoffs. We had some extremely emotionally debilitating layoffs. ... And so as the screw tightened I think relations became more strained in the newsroom, and Bob did not feel as comfortable with his news staff as he did in the beginning (recorded interview, July 16, 1994). With the economic uncertainty, the newsroom was becoming increasingly militant. According to Brand, the newsroom, at one point, was practically burning Maynard in effigy. He said, the whole time, everybody's bitching totally, all the time. Maynard's this, Maynard's that, grr, grr, grr. It's a whole background of total bitching and unhappiness. But underneath all that, it was a good place, it was actually a warm supportive place. A lot of people became lifelong friends because of the place (recorded interview, March 31, 1994). 
Raess, former assistant city news editor and deputy managing editor, said that it did become strained between management and reporters:

[I]t got bitter at times near the end because of the takebacks, the salary cuts, the continually worsening working conditions, but the underlying subtext at the Tribune was always we're in this together, all of us. We disagree about small stuff but we're in this together (recorded interview, July 9, 1994).

Former Executive Editor Aarons described his situation as being "very much pincered." He said:

That comes with the territory, but when the economic squeeze continued for so long and seemed so hopeless, I began to see that there was in truth no way through, and when you lose that sense of hope, you're just going through the unpleasantness of it all, and I realized at some point that it was time for me to move on.

Aarons left the Tribune in January 1991. Before then, many changes would take place within the executive ranks including the addition of Nancy Hicks Maynard to the management staff.

In the February 12,1988, issue of the Tribune, a story announced the naming of Nancy Hicks Maynard as vice president for planning to Tribune management (C-1, 6). Before the addition of Nancy Hicks Maynard, questions had already been raised by some newsroom staffers about the wisdom of Maynard's business personnel choices. The addition of Nancy Hicks Maynard as vice president for planning left some insiders 
with questions of what her role would be. They questioned not her competence but her expertise and qualifications for newspaper business management. There was the suggestion that bringing Nancy Hicks Maynard on board was part of a succession plan in light of Maynard's declining health.

Grimm suggested that the decisions Maynard had to make as owner were different from the decisions Maynard had to make as a newspaperman. He compared the Tribune situation with that of the San Francisco Chronicle:

The man running the Chronicle wasn't a street reporter. . . . He's a chief executive officer. That's pretty far removed from how you shape the lead. Maynard had to do all those things. In that sense, he had more opportunities to go on the wrong course. He had to necessarily, because of the scope [of his job], rely on more people for greater input. There were a number of executive changes. People came and went at various levels (recorded interview, June 14, 1994).

Aarons said of the business side:

There was a lot of turnover and what happened was we would bring somebody in--they'd have . . . a fresh start--we'd go off in a certain direction; we just didn't have the financial capability of sustaining it. That person would become disillusioned or Bob would become disillusioned with that person and they would be rotated. It's just kind of like a vessel floundering despite all the extraordinary minds that were operating. 
Raess, who came to work at the Tribune as an assistant city editor in late 1988, said that when he arrived, "The place was pretty much is disarray. Bob's vision of the place was always--I think--a little grander than what the paper could afford."

The management structure would eventually include only Bob and Nancy Maynard, Managing Editor Eric Newton, and Executive Editor and Senior Vice President Leroy Aarons.

When asked about Nancy Hicks Maynard's role, Craig Staats, former political reporter at the old Tribune, now the Oakland city government reporter at ANG, said: She had more of a role at the paper in the end. We had some union tactics that hurt her feelings personally. I know at one point when they were asking for another concession, the unions asked that she be fired, that she shouldn't be paid too, when we were having these cutbacks. So there were some bad feelings at the end. And I think there's probably some bad feelings today. I told Maynard at the end--I got locked into this confrontational role with him at the end--but that's just the nature of the business. He was management, we were labor. It's not personal. It's just you're looking to protect people who worked hard for a long time and just continued to give and give. It was just never enough (recorded interview, May 5, 1994).

From the management perspective, Aarons, who was a close personal friend 
of the Maynards, said:

I think one of the [Tribune's] largest financial commitments was the structure of the unions and some of the antiquated work rules that lingered from the era when the Tribune was an extremely prosperous paper and was up there with the [San Francisco] Chronicle and the [San Francisco] Examiner. You had these draft unions who were dominated by people who had been there for years and years. ... They fought every step of the way any possibility of reducing labor costs or any kind of reform. And I think that Bob, if you were to ask him today, would say that labor costs were at the heart of the incapability of the Tribune to survive.

The October 1989 Northern California Loma Prieta earthquake worsened the situation at the Tribune and may have also contributed to the Tribune's inability to survive. The disaster proved a small boon but a larger curse for the Tribune. The boon arrived six months later when the Tribune was awarded the Pulitzer Prize for photojournalism in the 1989 earthquake. Primarily because of the news coverage, the collapsed Oakland Cypress freeway remains a symbol of the earthquake's devastation and is permanently fixed in the mind's eye.

The larger curse was the loss in advertising revenue from major Tribune advertisers such as the Emporium-Capwell. The department store chain's Oakland downtown store was shut down for 10 months for repair work. The Tribune Tower was damaged in the earthquake. In the newsroom there were cracks running across the 
walls and the plaster would come crumbling down. Duct tape repair work lined the long cracks in the wall and patched the floor. Tenants vacated the Tower because of the earthquake damage and with their departure went a separate source of revenue for the Tribune. The actual amount of renter and/or lessee revenue lost was not obtainable.

The elation of winning the Pulitzer Prize was dashed by June 1990. It was a tumultuous month for the Tribune. It underwent the second of two staff reduction buyouts. Editorially, the Tribune moved to combine its southern Alameda and Contra Costa County local zone sections into one. The Metro section, covering Oakland and Berkeley, remained a separate section. A June 27th employee newsletter (Tribune marketing department, 1990) explained that the move would reduce the cost of producing two separate sections and offered advertisers more coverage (p. 1).

In the same employee newsletter was printed a Tribune organizational chart with the Durkee/Sharlitt, "turnaround effort" (p. 2). The Los Angeles-based consulting firm had been brought in to cut costs and restructure the company. Maynard reportedly paid three-quarters of a million for their services. On the hierarchy chart, the consulting firm sat on the second tier, directly across from Nancy Maynard, senior vice president for marketing, and right beneath Robert Maynard, president and editor.

From the management perspective, Aarons described the thinking behind all the Tribune's audience and editorial shifts:

Philosophically, the newsroom employees were focused on Oakland and the inmediate area. They also felt it made more business sense to become the best 
paper in that area. There were large pockets of circulation that the Tribune did not have within its own home area. . . I I was at a level of uncertainty because I felt sympathy with the notion of becoming the best damn paper in the immediate territory but at the same time, at that point as executive editor and ultimately senior vice president, and being in on all the corporate decisionmaking, I wasn't completely sure that this effort was not worth doing, as was Bob. We were desperately trying to find a niche that would allow the paper enough stability to survive the economic downturn. There was the disastrous earthquake. All these albatrosses popping up. So we were in a constant state of anxiety and turmoil over the economics of the operation to the extent that it stretched tempers. It created an us-and-them kind of mentality in the newsroom (recorded interview, July 16, 1994).

Still, some in the newsroom staff questioned if the situation was as dire as posed or if it was a management ploy to wring yet more concessions from them. It was after the earthquake that Staats, former political reporter and union guild chair at the old Tribune, now the Oakland city government reporter at ANG, recalled a big union meeting where there was to be a vote on some concessions and vacation time. Staats said:

I remember one of our guild auditors standing up and saying, "Well, you know, I've seen the books, by all rights Bob could ask for more. He's only asked for 
this. But if I were in his shoes I would ask you for more concessions." I think that was a signal to people that things were tough.

The "Urban Eastshore"

On February 26, 1991, at the bottom half of the front page of the Tribune, a headline announced, "The Tribune heralds a new beginning." It began:

The Tribune is coming home. Starting tomorrow, the Eastbay's largest daily newspaper will be renamed the Oakland Tribune, its title for nearly all of its 117 years. "This is our way of telling the world that Oakland, California, is a city reborn after years of decline,'" said Robert C. Maynard, the paper's editor and publisher.

And the paper, say the Oakland Tribune's top executives, is also being reborn.

Readers will notice a host of new features and a renewed commitment to covering the news of the urban Eastbay, said Managing Editor Eric Newton (p. A-1).

The front-page headline of that day's paper read "Retreat." Although referring to the Iraqi withdrawal from Kuwait in day 41 of the (1991) Gulf War, it could very well have alluded to the Tribune's announced move back to the "Urban Eastshore." The move was proclaimed as a recommitment to the eastshore, but it was also a final retreat from the suburbs of Contra Costa. At this point in the newspaper's existence, it may not have been a voluntary choice. The cost of zoning and distribution to southern 
Alameda and Contra Costa Counties was high and the returns were slow in coming. There was not enough cash flow to maintain the suburban assault.

In newspaper promos, a new slogan read "Oakland Tribune: Count on it." The text began, "If you live or work in the Oakland-Berkeley metropolitan area, you can't find a more informative, vital and useful newspaper than the Oakland Tribune" (p. A9).

It was a new beginning, but the new Oakland Tribune was not on firm economic ground. Staats said, "We would have a [financial] crisis and we might go seven or eight months, a year before something happened again. But at the end, it almost seemed like it was one continuous crisis."

The long running tug-of-war between Gannett and Maynard would be publicly aired. The Oakland Tribune workers would be informed in a "Dear Colleague" memo dated August 8, 1991, from Maynard. He recounted the last of a series of seemingly endless negotiations and renegotiations with Gannett involving its outstanding note, originally $\$ 17$ million, now accrued to $\$ 31.5$ million. It began:

During the months of June and July, Nancy and I were looking forward to the date of August 1, 1991. On that day, we planned to announce the news that the Tribune had secured a well-financed investor. We were going to have working capital, funds to pay off our creditors and new money for marketing and promotion. It was an exciting prospect (p. 1). 
It said, "One obstacle stood in the way--the note to Gannett." It explained, [o]ur debt to Gannett, which looms large on our balance sheet, has been the subject of previous unsuccessful transactions. A major media company that considered investing in the Tribune in 1988 walked away from the deal because of the Gannett note. The chief financial officer said the company was willing to put millions into the Tribune, but not a cent into Gannett for the note. That deal died, as have others over the years. Apparently this time, the investor was willing to pay Gannett something for its note.

The memo continued:

[s]o when we found an investor willing to pay Gannett $\$ 2.5$ million, we thought they would be glad to see us. Instead, they began constructing artificial barriers to a successful resolution. They insisted on knowing the name of the investor. Knowing their purpose was to try to jack up the offer, the investor declined to be identified. He did not want to get into a haggling hassle with Gannett. His position was Gannett's debt is probably worth nothing. The mere fact that it sits on the Tribune's balance sheet at $\$ 31.5$ million and grows at $\$ 300,000$ a month doesn't make it worth that on the open market.

Gannett's position was that the note could be worth between $\$ 6$ and $\$ 8$ million. In response, the memo said,

[w]e argued that if they could get that much for it, they should sell it immediately. Nothing happened. After weeks of going back and forth across 
the country and hours of phone calls, a spate of letters on the fax, one thing became certain. Gannett was not going to budge, and we here at the Tribune were running out of time without an investor.

Then the memo dropped a bomb. It said, "Seeing that this situation could go on no longer, we set a deadline. If no reasonable resolution occurs by next Wednesday, August 14, 1991, we shall have no choice except to close our doors" (p. 2).

It was obvious that negotiations with Gannett had not ended with the 1983 sale of the newspaper to Maynard. The ongoing negotiations between Gannett and Maynard were described by Aarons:

I think Gannett was very patient. But it became quite clear early on that the Tribune was not going to be able to keep up its agreement. There were interest costs that were just not getting paid--were building up millions of dollars and Bob kept trying to restructure the relationship with Gannett, and Gannett kept coming back and saying, "Well let's see a plan that's gonna show you in the black." That's one of the things that prompted all of these various experiments we were doing. We were coming up with different kinds of financial plans that would convince Gannett to change the debt into equity and take that negative off our books so that we'd have better standing with our advertisers and with bank financing. There was no line of credit. There was no cushion. There was no fallback when we started getting into the late ' 80 s. So what was happening was that we were living month-to-month, kind of kiting our way forward, not 
paying our bills until the next round of advertising money came in. So there it was like this family constantly running out of money before the month was out. It's hard to describe to you the incredible pressure we were under constantly every day (recorded interview, July 16, 1994).

The tug-of-war between Maynard and Gannett ended when Allen H. Neuharth, chairman for the not-for-profit Freedom Forum (formerly Gannett Foundation), agreed to provide the funds that would allow the Tribune to continue operating. It was that or be painted as the corporate villain that allowed the Tribune dream to die.

At the time of the announcement, there was celebrating, "tears and laughter and craziness all around," said Fagan, "but most of us knew that the wick had been lit. The place was gonna blow some time."

On February 13, 1992, a "Dear Colleague" memo from Maynard announced the official completion of Gannett's $\$ 32$ million note conversion to $\$ 5.5$ million in equity and \$2.5 million in interest-free debt. It said, "That process, begun last August, took much longer than anyone would have guessed at the time. All the same, its completion gives the newspaper a much healthier balance sheet with respect to its long-term debt."

But Fagan proved right. Indeed the wick had been lit. The Tribune was in a downward economic spiral. Maynard's declining health added to a trying situation. Although it is now history, it was not a surprise when on October 15, 1992, it was announced that the Oakland Tribune would be sold to Dean Singleton, owner of the Alameda Newspaper Group. 


\section{Chapter 5}

The Oakland Tribune and Its City

The previous chapter looked at the Maynard Tribune on an organizational level. This chapter was a broader analysis of the Oakland Tribune, examining it through a larger lens to include the environmental variables of its city's geography, economy, and technology.

Historically, the fortunes of a newspaper have been linked to the fortunes of its city. This chapter attempted to establish the linkages between the Oakland Tribune and its city. At the same time, this chapter provided the context for the Alameda Newspaper Group's (ANG) arrival in Oakland covered in chapter six.

Before embarking on an historical examination of the Maynard and ANG eras, this chapter first examined the Knowland legacy to the Tribune.

Under the Knowland family (1915-1977), the Oakland Tribune, for most of its 62-year existence was an economically viable daily. It was making a profit, breaking, even, or experiencing losses that were small enough to give the owner the expectation that there would be a return to profitability. Politically, it was the Republican voice for Northern California.

Police Reporter Harry Harris, who has been at the Tribune since 1965, said:

The Tribune had gone on for decades as a local paper that had control over two counties. ... We had reporters in every town in the East Bay. We had two or 
three reporters in some towns before they became incorporated as cities--and the Tribune was a really powerful force (recorded interview, June 2, 1994). In its heyday, Tribune circulation numbered in the mid-200,000s. In the mid1980 s, circulation remained steady at 150,000 . Beginning in 1990 , it began a steady decline and it now seems to have bottomed out in the mid-70,000s. The erosion of circulation has partially been the result of losses to suburban newspapers and an overall decline in newspaper readership. Other reasons for the decline were explored in chapter six.

In the 1970s, like many metropolitan dailies, the Tribune's readership declined and its advertising base eroded. Starting in the 1960s, many people moved from Oakland's inner city to the suburbs. Major downtown department stores like J.C. Penney and Liberty House either shut down or moved out to the suburbs. Suburban dailies sprang up to serve the outbound stream of people moving from the inner cities to the suburbs and capture the department store advertising that followed.

At this juncture in newspaper history, in the 1960s, the Knowlands chose not to follow the movement outward. Under the late William Fife Knowland, the decision was made to revert the newspaper back to its metropolitan core with the larger objective of becoming a regional newspaper focusing on state and international news coverage. The Tribune's expansion outward and consequent contraction under the Knowlands would be replayed again in the 1980 s under Maynard, but the economic circumstances would be greatly changed. 
Under the Knowlands, the link commonly found between a metropolitan newspaper and its city came apart, at least with respect to its local community. The relationship between the Tribune and the city's burgeoning minority population was at first non-existent and later strained. Oakland began to experience what a lot of other urban centers across the country were undergoing: white flight, urban decay, and capital flight.

The demographic changes that were overtaking the city's general populace would eventually be followed by changes in the city's political and cultural elite as well. It was a change which the Knowlands did not quite know how to respond. Rivers and Rubin (1971) wrote:

It is not unfair to say that the Tribune is wary, if not downright fearful, of what its city is now and what it may become in the next few years. A number of reliable sources have speculated that Oakland may be as much as 80 percent Black [sic] within the next five to 10 years. Relations between the paper and the Black [sic] community are already strained. How the Tribune adapts itself to the changing urban environment in the near future makes it worth watching by the rest of the nation's metropolitan press (The Detroit News has already opted to focus on the suburbs.) (p. 46).

In 1977, the Knowland family Tribune was sold to the Phoenix-based chain, Combined Communications. Combined owned the daily for two years, before it was 
acquired by Gannett as part of a larger merger with Combined. Gannett owned the daily for three years before selling it to Maynard.

A nationwide recession bottomed out in 1976. Across the U.S. there were pressing growth issues to which the newspaper industry attended. This was particularly true for metropolitan newspapers. As chains grew, the newspaper industry experienced the parallel development of declining readership. In the 1970s, declining newspaper readership became a major concern for many metropolitan dailies. Circulation growth did not keep pace with adult population growth. Daily newspapers increased their circulation in the late 1970s after more severe declines in 1974 and 1975 , but in 1978 it was still about a million below the record 63.1 million of 1973 (Hynds, 1980, p. 159). In 1976 , the Tribune's circulation numbered in the 180,000 s.

In a search for answers to declining readership, the American Society of Newspaper Editors commissioned a 1977 study to find out what readers wanted from their newspapers. The study was funded by the Newspaper Readership Council and carried out by Yankelovich, Skelley, and White under the direction of Ruth Clark. The study sampled 12 different daily newspaper markets using focus groups.

The results of the study led to a series of recommendations on how newspapers could modify content to better meet the needs of their readers. They encouraged "strong local coverage" because it "produces the strongest ties between readers and editors." On the other hand, the study warned against "weak or indifferent local coverage" because it "is a major source of alienation" (Clark, p. 4). 
The study said:

In the focus groups, there were numerous complaints about editors who seemed more interested in cosmic events than in local affairs, who habitually play down local stories on the front page, who sometimes come from other cities and don't even know their communities. . . Many readers made the telling point that local news coverage is far too heavily oriented toward government and politics because editors concentrate on obvious news sources, such as City Hall and do not routinely send reporters out into neighborhoods for grass roots coverage (p. 4).

The marketplace and times were changing. Increased market pressures spawned more reader surveys and focus groups to find out what "desirable" audiences wanted. The Tribune would not be unaffected. Clark would issue similar recommendations for the Maynard Tribune when she conducted a readership survey for the newspaper in 1986.

At the beginning of his ownership, Maynard believed, according to Leroy Aarons, former executive editor and senior vice president, that readers would be the natural outgrowth of good journalism and that the community and readers would respond to a newspaper offering quality journalism (recorded interview, July 16, 1994). Although logical and rational, the formula for attracting readership appeared to have been more complicated and perplexing. It is a formula that the newspaper industry, with all of its studies and readers surveys, is still trying to pin down. 


\section{Economic Structure}

Newspaper revenue comes from two main sources: advertisers and readers. A small-to-medium-sized daily with a 34,000-daily circulation tends toward a 70/30 revenue ratio of advertising to circulation; larger, big city papers tend toward an 80/20 ratio (Compaine, 1980). A newspaper like the Tribune would be comparable to the latter, with an $80 / 20$ revenue ratio of advertising to circulation. Advertising revenue itself is composed of retail, classified, and national advertising.

Fred Wetton, retired vice president of advertising and business development, said that about $50 \%$ of the Tribune's advertising revenue came from retail, $40 \%$ came from classified, and the remaining $10 \%$ came from national advertising (recorded interview, December 1, 1994). With half of its ad revenue in local advertising, the fortunes of the newspaper were heavily dependent on the fortunes of its city and surrounding area. Starting as early as the 1960 s, but continuing into the 1980 s, many local stores and major department stores either shut down or relocated away from downtown Oakland and Oakland itself. The Tribune somehow had to make up the retail losses. Wetton explained:

That's why it was important for us to be viable in the suburban areas: to maintain some kind of circulation penetration in the suburban areas where the major shopping centers were. If we could convince our advertisers through our research that we still had an ample number of readers in the suburban areas, we could still retain a good portion of their advertising; that was really the 
challenge because there wasn't a lot we could do about Oakland. The retailers had pretty much left Oakland. So, in order to maintain that large retail base, we had to convince our advertisers that we were viable in the suburbs (recorded interview, December 1, 1994).

Wetton described the situation of the Tribune as being "between a rock and a hard spot," because "you're an Oakland paper and you certainly have to cover the local community, but at the same time, in trying to retain the advertising, you had to do something to get that suburban reader." One of the tactics employed by Combined Communications and Maynard to attract a broader audience was to remove the city's name from the newspaper's title, calling the newspaper The Tribune.

Removal of "Oakland" from the title was a simple solution with little impact. Tribune management faced a larger dilemma. It was a common metropolitan newspaper dilemma: continue to serve the inner city audience and lose advertisers or serve an outlying suburban audience with the purchasing power to attract advertisers. The ideal situation would have allowed the Tribune to pursue the affluent audiences in suburban Contra Costa County or the Oakland and Berkeley hills, and still somehow continue to serve its inner city audiences. The other solution was to wait and hope for an economic revival in Oakland and its downtown. Both choices represented substantial risks and costs. 


\section{The Outlying Suburbs}

For metropolitan newspapers, comprehensive suburban coverage was an expensive proposition because of the existence of multiple municipalities. The reporting staff and distribution costs associated with outlying areas required investments in bureau offices, more trucks, and truck drivers. Sachsman and Sloat (1985) in their study of suburban New Jersey newspapers, explained why:

The circulation areas of New Jersey suburban newspapers often include dozens of different municipalities in two or more counties. Thus providing adequate local coverage in the suburbs is a much more difficult task than in an urban environment, where there is centralized city government. Suburban reporters must spend a good deal of their time driving from town to town and meeting to meeting just to find out what is going on. Solid suburban journalism requires large news staffs and large news holes, and while a surprising number of New Jersey newspapers get the job done, even 30 local stories a day does not necessarily mean a daily story for each municipality (p. 7).

The Tribune expended much effort covering the cities in western Contra Costa County, southern Alameda County, and the Contra Costa/Tri-Valley area (the Pleasanton, Livermore, and Dublin area), in addition to metropolitan Oakland and Berkeley. The Tribune opened bureaus in Fremont, Martinez, and Walnut Creek. The entire suburban coverage area included 32 cities, not counting unincorporated areas. Of the effort, 
former Executive Editor and Senior Vice President Leroy Aarons said:

Now, of course, the Tribune had limited resources and we did do some additional hiring, but we mostly stretched thin the resources we already had, the argument being that we may have had too many people covering a smaller area and that we could stretch it out (recorded interview, July 16, 1994).

Among metropolitan newspapers, the Tribune was not alone in its decision to reallocate its labor and resources to outlying suburbs. For some newspapers, it was an issue of raising greater revenue. For others it was an issue of survival. A zoned edition attracted community advertisers outside the metropolitan core by offering parts of the newspaper's circulation.

Benny Evangelista, current business writer under ANG, became the Fremont bureau chief during the move out to the suburbs. He said, "When [Maynard] started [the Fremont bureau], I think he had envisioned something like the L.A. Times bureau like they have in Orange County. At one time, we had eight or nine reporters, at the height of it, covering Fremont, Newark, Union City, San Leandro, San Lorenzo" (recorded interview, April 19, 1994). Evangelista continued:

I thought it was going to work. I mean the revenues were there. They had to be grown. We didn't do enough marketing of the zone so people knew we were there. But we were getting some of the advertising. They'd offer it at discount rates so they would put ads in whatever zone it was--the southern Alameda 
County zone or the Contra Costa County zone--but it wasn't coming fast enough. The revenues weren't coming in fast enough to save the paper. . .

The theory was to grow revenue to keep up with the growing expenses of the paper as a whole. The idea was to reach out to the suburbs because the advertising dollars were not in downtown Oakland or the core area of the Tribune to sell. It just wasn't there. I think [Maynard] later admitted what he should have done was to cut costs back then, keep his cost structure more in line with the revenue stream, and then grow the paper from that point. Part of that was, he didn't want to cut anybody, so he tried to grow the revenue so he could keep everybody.

In the suburban move, there came a greater variety of suburban news mixed with news of the metropolitan core areas. Yet how effective the effort was in attracting enough advertisers to support the move is unclear. For many metropolitan newspapers that moved into the suburbs, success was not assured. Sachsman and Sloat wrote, "The list of the dead [newspapers] and the circulation losers is almost exclusively a list of urban newspapers unable to gain from the suburbanization of the state and unable to compete in a changing environment" (p. 5).

In the Bay Area, suburban areas continued to extend outward, moving people and businesses further away from the older cities like Oakland. Urban newspapers like the Tribune, stretched its resources trying to play "catch-up" with suburban newspapers 
firmly established in the 1950 s or 1960s. Retired Managing Editor Roy Grimm said: "It was a costly move" (recorded interview, June 14, 1994). Several interviewees agreed. In covering the entire area, the Tribune had to be zoned for West (Contra Costa) County, southern Alameda County, and the Contra Costa/Tri-Valley area, which equalled a multimillion dollar effort.

Eventually, the Walnut Creek and Fremont bureaus were gradually dismantled and closed down. The Fremont office, which at one point was a full office with advertising, classified, and circulation staff, closed down in 1989. The remaining staff was moved back into the rent-free county office in Hayward. It was a lean time for the Tribune, and the worst was yet to come. For newspapers nationwide, 1989 was the year that the economy began its downward cycle, "culminating in the 1990-91 recession (Crutcher, 1992, p. 40). At that time, the Tribune refocused on its "natural market," which included "Vallejo down to, say, Fremont," said Mary Ellen Butler, former editorial page editor (recorded interview, June 23, 1994). It was called the "Urban Eastshore" plan, which was first made public in 1991. From the perspective of many newsroom individuals, that was where the paper should have been focused. The advertising standpoint was somewhat different. Wetton said:

Well, from an advertising standpoint, I guess there was a little disagreement on whether that was the right concept or not, because certainly. I think we had to make the effort. ... When Hilltop shopping center [in Richmond] was built [in September 1976] . . . it never made its projections. For years, that center was 
under its projections. If you looked in that direction the retail was not really strong out that way either. Now today you have some of your mass merchandisers out that way. You can find Costco and Home Depot. They're out there now. But back in 1989, '90, '91, when the decision was made [to focus the Tribune's news coverage in that area], they weren't there yet, so the potential was still somewhat limited as compared to other areas. But we seemed to do better as a newspaper in that area so it seemed like a logical area to enter (recorded interview, December 1, 1994).

Stores like Costco and Home Depot were the end result of local retail restructuring. Crutcher (1992) argued that retail advertising at the time (1989-91) was depressed because of such local retail restructuring (p. 40).

Looking back, then-Assistant Managing Editor Eric Newton believed that the "Urban Eastshore" concept was beginning to take off when the 1989 Northern California Loma Prieta earthquake occurred. Two years later, a huge fire would devastate the Oakland/Berkeley hills in October of 1991. A large portion of the homes belonging to affluent Berkeley and Oakland residents went up in the flames. Newton, now the managing editor of the Freedom Forum Newseum slated to open in 1997 in Arlington, VA, said:

The tragedy is just when the paper was just starting to get this very good urban East Bay identity and really starting to become cohesive--we started a twodays-a-week special edition for Berkeley--I think we were heading in just the 
right direction [when] the earthquake happened and then the recession happened. And we, you know, shoulda, coulda, woulda. If we had the economics of the early '80s with the "Urban East Bay" identity--the way things were starting to click contentwise later on--I'd probably be on the West Coast talking to you right now instead of the East Coast (recorded interview, April 16, 1994).

The Oakland/Berkeley hills fire came on the heels of the 1989 Northern California Loma Prieta earthquake, and it could not have come at a worse time for the Tribune. It came at a time when the newspaper was well into its attempt to refocus its efforts back on the metropolitan core of Oakland and Berkeley.

Yet despite the earthquake and fire, the metropolitan core had already shown itself to be a tough market to serve because of the socioeconomic disparities within the city of Oakland. Moreover, the affluent segment of the metropolitan core proved a tough market to crack because the San Francisco Chronicle already had a strong toehold there.

\section{The Metropolitan Core}

The primary communities that made up the Tribune's metropolitan core included Oakland, Berkeley, and Piedmont. Since the late 1970s, the city of Oakland has had a majority minority population. In 1991, the median price for a single family home in East Oakland was $\$ 129,000$. In much more affluent Piedmont, the 1991 
median home price was $\$ 475,000$. The disparity has led to the distinction between the poorer "flatlands," and the affluent "hills."

Although Oakland was considered to be quite diverse, some neighborhoods in the metropolitan core were either heavily white or black. According to an $U p C l o s e$ (1991) demographic summary, Eastmont, which is at the east end of Oakland, was $90 \%$ black and $3 \%$ white. Piedmont, in the Oakland hills, was $82 \%$ white and $3 \%$ black. Although these examples fell at the extreme ends of the spectrum, they illustrated the different realities and needs of the Tribune's audience.

Today, Oakland's beleaguered downtown shows a few signs of revival, mainly in its Chinatown and in the recent construction of the twin Federal government building. Other government office buildings include BART (Bay Area Rapid Transit) and EBMUD (East Bay Municipal Utility District). They occupy separate blocks in downtown Oakland. The only major department store in downtown is the Emporium. The city's only mall, Eastmont, has experienced the closure of two major anchor stores, J.C. Penney and Mervyn's, neither considered to be upscale department stores. In downtown, the Pacific Renaissance Plaza was built with foreign capital and sits at the outskirts of Chinatown. Other signs of small-scale commerce include several Vietnamese restaurants and many grocery and jewelry shops near Chinatown. The department storefronts that were formerly Liberty House, I. Magnin, J.C. Penney, Grodins, and Sears remain closed, and some are boarded up. Add to the list of the many closed edifices: the earthquake-damaged Tribune Tower. Although the Oakland 
Tribune continues, its Tower stands empty, unused, and still earthquake-damaged. The Tower was not part of the ANG purchase. The structure reportedly belonged to Topa Thrift and Loan Association, a Covina, CA-based firm, as of April 1993, when the Tower underwent foreclosure proceedings.

The Tribune Tower and Technology

The number of traditional metropolitan newspapers are waning. The now-empty Tribune Tower stands as a symbol of that decline. Today, the Tribune Tower remains an historical downtown landmark. With its characteristic green steepled crown, the Tower is one of the most recognizable structures of downtown Oakland's skyline. Before the earthquake, it was a source of rental revenue.

The presses in the Tower dated back to the Knowlands. They were extremely out-of-date. Before and after the earthquake, there was a lot of deferred maintenance on the building, the presses, and the computer terminals. In regard to the presses within the Tower, Wetton said, "The problem for the Tribune was the cost was so high. It was a costly operation. It wasn't practical to have a vertical plant. It was a high cost of operation for a paper its size" (recorded interview, December 1, 1994). Many newspapers now have satellite plants, which cut down on the cost of distribution to outlying suburbs. Since the sale, the Oakland Tribune has been printed in ANG's Hayward and Pleasanton plants. Both cities are in suburban areas of Alameda County. 
Besides building satellite plants, the heaviest expenditures for many newspapers in the past two decades have been for new equipment to develop electronic newsrooms, replace hot metal operations with cold type, and shift from letterpress to offset printing (Hynds, 1980). Gannett was the owner that could most afford to make the sorts of long-term capital investments necessary to modernize the Tribune equipment, but it did not. Gannett poured money into the front end of the operations but left most of the Tower's equipment and infrastructure untouched. Gannett hired enough personnel to get out both editions of Eastbay TODAY and the afternoon Tribune. The company purchased racks and trucks but did not make improvements to, much less replace, the presses.

Inside the Tower, the newsroom was located on the fourth floor. Reporters on that floor worked on dumb terminals (Dumb terminals are display terminals that contain only input and output capabilities and are entirely dependent on the main computer for processing; this is different from terminals with built-in display characteristics and processing capabilities.) It was an aging system, and the original manufacturers no longer made replaceable parts for it. Craig Staats, former political reporter, and now the city government reporter at the ANG Tribune, said, "You'd come in and find that someone cannibalized your machine so theirs would work. It was a real ancient system" (recorded interview, May 5, 1994).

The mainframe that handled the online terminals sat on a separate floor, and according to Lester On, retired reporter and slotperson, when the air conditioner broke 
down, so would the mainframe because of overheating (recorded interview, March 10, 1994). Staats said, "If [maintenance] heard a paper was going out of business somewhere, they would buy the used parts just to keep the [mainframe] going because they couldn't get them through regular suppliers anymore--it was so ancient. They were like the guys you read about in Cuba that are keeping these 1955 American cars running by hook and crook, just trying everything they can."

By many accounts the computer system was on its last leg near the end of the Maynard era. Mary Ellen Butler, former editorial page editor, said:

Near the end, the computer system just virtually broke down, and many, many days, many, many, many times, the computer system would crash, and that was no longer fun because it did hamper the production of the newspaper. . . .

[T] here were times when the copy actually had to be rushed over [up] to the [San Francisco] Examiner or even down to the [San Jose Mercury News] Merc (recorded interview, June 23, 1994).

The fleet of distribution trucks had not been entirely replaced since Gannett purchased a new fleet of trucks in the early 1970s. Johnny Wong, who had worked in the circulation department since 1978, said, "We had [new] 1979-to 1981-make vehicles [when] Gannett replaced the fleet." In the later years under Maynard, one of the ways that the Tribune procured supplies, including trucks, was by bartering. Wong said, "In 1990, we got four or five new trucks by working out a deal with a Chevrolet dealer--bartered for advertising." Like the aging computer systems and presses, the 
trucks also began to constantly break down. Wong said of the trucks, "The garage tried to repair them as fast as they could. In the last few years, when the trucks broke down, they took parts from other trucks in order to fix them" (personal communication, May $15,1994)$.

It was against this backdrop of finite resources, aging infrastructure, and a shrinking advertising base that the Maynard Tribune endured for nearly a decade. In that decade, there were many attempts to increase the paper's profitability using many resourceful and novel approaches. Some worked, some did not. In spite of the economic hardship, the Maynards and the Tribune remained involved with the local community, from doing investigative stories that uncovered corruption in the Oakland public schools to sponsoring publisher forums on youth violence.

Involvement in the community made sense because the fortunes of the city were linked with the fortunes of the newspaper. Yet in order to continue to serve its public, the newspaper had to serve itself by being profitable. It could do that only if it had enough local advertising to pay the bills. Raess, former assistant city news editor and deputy managing editor, said:

Bob was extremely interested in the health of Oakland. And when they [the business department] went too far in the Tribune, it was usually because it was connected with downtown Oakland. When the new Emporium opened after the earthquake. .. . They [business department] wrapped the Tribune with a fourpage section, basically written by marketing and advertising people, that looked 
like the Tribune--and it was all about the Emporium opening--this advertiser. And they hawked that in the streets of Oakland. It was a terrible embarrassment for the newsroom. We felt like we totally prostituted ourselves. The paper appeared to be whoring itself for the sake of advertising (recorded interview, July 9, 1994).

From the business perspective, the Tribune was doing what it needed to do to survive in a tough urban market. As owner, Maynard was caught in the middle trying to ensure that the Tribune did not die.

The causes of death of many metropolitan newspapers have included an inability or unwillingness to expand to the suburbs, a failure to adapt to changing circumstances, or a shutout by competition (Sachsman \& Sloat, 1985). The Oakland Tribune faced all three yet still somehow endured for nearly a decade under Maynard.

Today the Oakland Tribune has a different owner. The culture and organization of the former Oakland Tribune as it was known is gone. The Maynard legacy may live on through the individuals that remain at the Tribune, but the Tribune organization itself has been replaced by a new corporate face. 


\section{Chapter 6}

\section{The Alameda Newspaper Group Tribune}

Maynard's struggle to keep the Oakland Tribune operating ended on October 15,1992 , when it was publicly announced that the metropolitan daily would be sold to Alameda Newspaper Group (ANG) owner William Dean Singleton. At the time, the newspaper had a staff of about 620 , and ANG expected to rehire 250 people for the Tribune (Stein, 1992, p. 38).

The newspaper was sold for a sum reported to be close to $\$ 10$ million, with ANG agreeing to pay a total of about $\$ 17.5$ million over the years after 1992 for the newspaper's name and subscription list.

Specifically, the sale included the Tribune trademark and use of its name, its advertising accounts, and circulation list. It did not include the aging presses, hardware, or the Tribune Tower which remained damaged from the 1989 Northern California Loma Prieta earthquake.

It has been two and one-half years since Tribune readers were "Welcome[d] to the new Oakland Tribune," on December 1, 1992, by its new owners. The front page story announcing the changeover read:

The "new" Oakland Tribune. Here it is. We hope you like it. You'll find nearly all of the columnists and standing features from the predecessor Tribune, plus an array of new ones. 
There's also a lot more advertising. And much more local news ... (p. A-1).

In that same issue was a promo piece that read: "Our son scored the winning touchdown. TELL EVERYONE! If it's news to you, make sure it's in the Oakland Tribune" (p. A-5). The piece had a different appeal and flavor than one of the Maynard Tribune's first ads promoting it as "the Intelligent Alternative" (1982, p. A4).

The Tribure's audience was more urban and larger than ANG's other East Bay audiences. Demographically, the Oakland audience was perhaps most like readers of the Hayward Daily Review which served Hayward and Union City in southern Alameda County, but it was three times as large. Readers of the Alameda Times-Star in Alameda and the Tri-Valley Herald in Pleasanton were demographically different.

Today, the new owners assert that the Oakland Tribune is a viable newspaper. ANG, however, is a privately held company and the owners have released no figures to support the claim.

At the time of the sale, ANG said that it was assured a circulation of 95,000 . After conducting an audit, ANG assessed the circulation to be closer to 75,000 . The discrepancy, ANG explained, was the result of unpaid accounts and duplicate circulation. The company believed that there existed 20,000 unpaid accounts and between 10,000 and 12,000 duplicate circulation--primarily from the Alameda TimesStar and the Hayward Daily Review. 
For those familiar with Bay Area journalism, ANG represented a different journalistic tradition from the Maynard Tribune. Maynard was a prominent journalist from the Washington Post. As owner, people expected him to foster hard-hitting urban journalism. Even though Singleton owned the Denver Post and Houston Post, ANG was viewed primarily as a suburban chain. Those unfamiliar with ANG didn't really know what to expect. They were suspicious, wary that the Tribune would be reshaped in the mold of ANG's other smaller East Bay dailies. ANG may have been very aware of this perception. Pearl Stewart, who had once worked under Maynard as a features editor, made journalistic history as the first black female to be appointed editor of the Oakland Tribune in 1992. In discussing her responsibilities as former ANG Tribune editor, Pearl Stewart said:

I was mainly to direct the editorial portions of the paper and to decide on matters affecting the editorial content. ... I think, moreover, they wanted me to represent the paper in the community and to kind of be their emissary to the Oakland area. ANG, at that time, wasn't really that well known. And certainly within Oakland, what was known of it wasn't necessarily appreciated because of their ownership of the Hayward paper and some of the other suburban papers. It was kind of viewed negatively by some people in the community. I think it was clear that they wanted someone as editor who could let the community know and perhaps let the skeptics know that the paper was going to be reflective or representative of the people of the area and that they were not 
trying to bring a suburban image to an urban paper (recorded interview, November 12, 1994).

When asked about his vision for the Oakland Tribune, current owner Dean Singleton said:

Long term, Oakland is gonna be drastically revitalized. We think that Oakland has a great strategic location in the Bay Area--that it's prime real estate--and that while it's gone through some very difficult times through the years, we think Oakland because of its location will over time be reinvigorated and will thrive. Our job is to see that the newspaper participates as a part of that (recorded interview, November 14, 1994).

Singleton openly talked about a more market-oriented approach to journalism. If Singleton's philosophy takes root at the new Tribune. there may be a blurring of the traditional boundaries between editorial and business departments. Some media experts have argued that this is how it must be for a "mature product" like the newspaper with its "high primary demand and declining market penetration" (Compaine, 1980, p. 221). Compaine argued that:

A purist may bristle at the idea that newspapers can be marketed like packaged goods. In many respects, they must be. For many years, newspapers were sheltered from this need because they had a near-monopoly in respect to other newspapers and even other media, at least until radio and television. But as some newspaper executives have finally realized, a newspaper which is not 
purchased does no one any good, no matter how fine the editors think the paper may be. An important step was undertaken by the industry with its readership project, a large scale field study to help determine why people read--or do not read--the daily paper. Hundreds of dailies started their own surveys in 1978 (p. 221).

This newspaper-as-a-product viewpoint was echoed in a 1983 interview with Singleton for the New Jersey suburban newspapers study by Sachsman and Sloat (1985) discussed in the previous chapter. At the time, Singleton was Trenton Times president, under Allbritton Communications of Washington, D.C. (owned by Texas millionaire Joe L. Allbritton). Singleton said:

We do not feel an obligation to print what we think readers ought to know, but what they want to read. ... Some people think a newspaper is a hallowed institution. A newspaper is a product, like a candy bar. You have to package it to be attractive to the reader. You have to put in the ingredients they want. You have to market it properly (p. 123).

When asked if he still held similar views as those he held at Allbritton Communications, Singleton said:

That was a long, long time ago. But I do believe that if newspapers are to succeed they must be marketed as a product. I think a newspaper is more than a product. I think a newspaper has a heart and soul. It has a history that perhaps a candy bar doesn't have, so I wasn't trying to say that the newspaper 
is first and foremost a product but saying that its success, long term, depended on it being marketed as a product. It's much more than a product. It's a heart and soul and a history, but it must be marketed as a product otherwise it can't succeed in its long-term goals (recorded interview, November 14, 1994).

When asked about the Tribune's advertising situation, Singleton said that it has improved dramatically because there now is more advertising than there was under the old Tribune:

There's a lot more advertising now. ... It was difficult to sell the Oakland market to advertisers by itself because the Oakland market wasn't big enough to attract the attention of major advertisers, by and large. But when we bought [the Oakland Tribune], it began selling advertising in combination with the other four daily newspapers, we provided a marketplace almost as large as the San Jose Mercury News and big enough for an advertiser to need and appreciate. So by putting the five together, it improves the advertising exposure in all of the newspapers and especially the Oakland Tribune. The Oakland Tribune was not a large enough marketplace which is why the Oakland Tribune in its old form failed. The Oakland Tribune on a stand-alone basis had a much bigger expense burden than it had a revenue opportunity to cover it. By combining operations with the other four newspapers, we were able to spread the expense burden and to spread the advertising opportlinity to make it successful (recorded interview, November 14, 1994). 
All five ANG newspapers, the Alameda Times-Star, the Hayward Review, the Fremont Argus, the Tri-Valley Herald, and the Oakland Tribune, now share common sport, business, and CUE (entertainment) sections. Former Editor Tim Schreiner, who replaced Stewart in February 1993 (Schreiner left in December 1994, see p. 123 for recent editor appointments), said, Common sections are "one of the reasons why the Oakland Tribune makes money today and didn't three years ago. When you share sections like the entertainment, business, [and] sports sections, the economies of scale help you save a great deal of money" (recorded interview, November 25, 1994). When asked if the papers share news from the front and local sections, Schreiner said: Well, we share it in the sense that it's available to all of us. Anything that one newspaper does is available to us at [all] the newspapers. We are all responsible for our local news sections, and we put in there, primarily things we have generated in our own newsrooms and only pick up from the other newspapers things that are such compelling news that they are picked up in all the other papers in the same way.

Of the combined sections, former Editor Pearl Stewart said:

I think it's definitely problematic. First of all, what I think they took for granted was differences between these communities. I think there was a reaction initially to the product and especially to the people who saw the Tribune and also the other papers. . . Oakland and suburban readers who saw the Tribune and the other papers described them as sort of clone-type products. 
Replicas of each other. I think there was some strong negative reaction to that because, especially in a large city, the size of Oakland, I think there was this idea that it needed a paper with more of a separate identity and a concern that it couldn't adequately reflect the community, if in fact, it was part of this larger group and that the other four were all suburban papers (recorded interview, November 12, 1994).

On March 31, 1995, the Oakland Tribune announced the appointment of Assistant Managing Editor Christine Lavin to the position of editor. Peggy Stinnett, Tribune columnist, was named editorial page editor (1995, p. A-3).

After the ANG takeover, the editorial pages of all five ANG newspapers were governed by a single editorial board. Mary Ellen Butler, former editorial page editor, retained her position, but she said, "The overall tone and philosophy of the editorial pages were monitored by the existing editorial page editor [of the other four papers in the group] and I became more or less like a deputy." She continued:

Now that might have been okay for me. If my duties had changed and I had functions more like a deputy editorial page editor and had lost the autonomy of one of my own pages, perhaps I could have lived with that. The other problem though was that we had philosophical differences that proved eventually to be increasingly uncomfortable for me. .. I was coming from the perspective of a journalist who happened to be black. Usually the gender thing didn't come in. Sometimes, it was a matter of my perspective as a black person. We have a 
different history than the perspective of the editorial board, which except for Pearl Stewart, was all white and all male. Except just before I resigned [in February 1994], another woman was added to the editorial board. But their history and their life experience was very different than mine, so we would often have different viewpoints. I was just one person on that whole board, so I was usually countermanded (recorded interview, June 23, 1994).

Craig Staats, current political reporter, talked about a different company culture under ANG:

They're very bottom-line oriented. It's real hard to get money out of them. . . Bob would spend money that he probably didn't have, and these folks won't spend money that they probably have. You know, I guess it's like the old joke: How do you get rich?--you don't spend any money. If you have money and don't spend it, you build it up. That's my biggest frustration. There's some good news people in this new organization. In ANG, they know news and they want the thing to work, but it's just a little different culture in how you spend money (recorded interview, May 5, 1994).

When asked about ANG's more business-oriented approach, David Burgin, ANG senior vice president and editor-in-chief, said:

Well you gotta survive. It's a matter of perspective. My training is all journalism. I'm just as true to those principles as you are, as anyone else is. But this has been a very difficult thing for the Tribune, and it was a calculated 
risk and until we were out of the woods, we didn't spend the money on it that some would have liked. But I think that those that survived and those that are here will tell you it's not so bad. You know from the business point of view, you cannot be an artistic success unless you're a financial success. I don't care or give a damn who you are or what newspaper you work for. If the New York Times starts losing money tomorrow, watch for layoffs. It's that simple (recorded interview, September 13, 1994).

Of the news coverage, Harry Harris, veteran police reporter, said:

I think we cover the local news here a lot better and the main reason is not because the writers are any better, not because ANG is any better, but it's because we don't have to worry about covering suburbia so much. We can direct our resources here at the Tribune to [the Oakland] area, which is our target area (recorded interview, 6/2/94).

The Tribune's core audience as defined by ANG's Singleton is the same audience defined under the Maynard Tribune's 1991 "Urban Eastshore" plan. When asked about the Tribune's audience, Singleton said, "We don't really draw lines. The Tribune's core market is Oakland, Piedmont, Berkeley, western Contra Costa County, and the town of Alameda, which is very similar to what [the Tribune's core market] always was, but it also has readers throughout Alameda County."

Singleton said that the Oakland Tribune is strong today, and he attributed the Tribune's return to viability to his organization's economies of scale. 
He explained:

We integrate everything. We integrate the production, share overhead, share advertising sales; we share circulation; we share editorial. The Oakland Tribune has our largest single newsroom. But then all of our newspapers share editorial copy. So by sharing all of that, it allows us to get a lot more bang for the buck, and so by sharing expenses and sharing revenue, it's made the Oakland Tribune a very viable newspaper.

Schreiner agreed that the sharing of editorial copy has made the Tribune more viable than it was three years ago. He also said that the physical separation of the newsroom in Oakland, and the copydesk and printing presses in Pleasanton was hard to get used to:

It's not like the structure at any other newspaper, and it's very difficult. . . . Not only is the structure different, in terms of now you've got a sports editor who really answers to somebody other than the editor--entertainment and business editors are the same way--but you've also suddenly got a newspaper where the copydesk and printing presses are not in the same building. And that's very difficult because you know the places where I'd been the editor before, you walk back and look at the pages on the flats in the production part of that building, and you see the page the way it's going to look in the newspaper and say that doesn't work, let's redo that. . . Well, when the copydesk isn't in the same building you're in, I see the paper in the morning. I 
pick it up on my doorstep, and that's very hard to get used to. And that also is the future of more and more newspapers (recorded interview, November 25, 1994).

Satellite plants have become more common among newspapers. If Schreiner is correct, then ANG will perhaps be recognized as the owner that moved the Oakland Tribune into the future, at least in terms of production. In other areas, ANG has not yet begun to utilize the emerging electronic technologies currently available.

Since arriving in Oakland, ANG has continually fought negative perceptions of it dispensing mediocre suburban journalism. It has also had to deal with negative reader reaction to some of the editorial stances it has taken on public issues. The most talked about was the pro-development stance it took on the Dunsmuir Ridge Development proposal which alienated a large segment of its Oakland hills audience.

It appeared that that first year was a rocky one, and it is difficult to tell what the future holds since so little time has elapsed. William Brand, former and current Berkeley bureau reporter, said of ANG:

Actually, they've had a very sobering experience this last year and a half, and now they realize that suburban journalism doesn't work in Oakland. We don't really care about what happens out there, and they don't really care what happens in here--we're different worlds. And so they're starting to listen, and they're smart, I'll give 'em this. . . They want to know what to do to make it like the old Oakland Tribune now. They realize that we did have something. So 
that's to their credit. You know, they're pretty sharp business people. And they brought in a publisher--I think maybe he's okay. We'll have to see. Who knows? It's a funny business (recorded interview, March 31, 1994).

If the Oakland Tribune is now economically viable as claimed, and has completed its ownership transition, it could be an interesting future case study of a newspaper whose fortunes were seemingly turned around despite the decline of its city. With its satellite production plant in Pleasanton, the ANG Tribune has joined many metropolitan newspapers which have moved their facilities away from the city. But with the move came new production routines and deadlines that had an impact on the editorial content and the ways in which the newsroom gathered and edited its news. The employees have no union contract. There is no working relationship between management and the union.

It is not known if ANG will invest in or adopt the emerging technologies that can take it into the future. Many questions remain unanswered. Perhaps the most significant question that cannot yet be answered is: How committed is ANG to Oakland and its newspaper?

The next chapter presented the findings of the media-level content analysis. The discussion that follows provided some insight into the impact of the organizational differences already discussed. 


\section{Chapter 7}

Content Analysis Findings and Interpretation

This chapter presented the findings and interpretation of a qualitative content analysis that examined (a) news type focus, (b) geographic focus, and (c) diversity levels of columnists and reporters, for the Oakland Tribune during ownership periods under Maynard for the years: 1984-85, 1987-88 and 1990-91, and under ANG for the year: 1994.

As explained in the methods chapter, years were purposively chosen to capture the beginning, middle, and end of the nine-year Maynard period. For ANG, the calendar year 1994 was chosen because it was the latest whole year that fit within the time frame of this study. The first year of ownership for both Maynard and ANG was excluded because of possible irregularities in news coverage resulting from the ownership transition.

It is important to point out that the time frames for the Maynard and ANG ownership periods were very different--nine years versus two years--and direct comparisons could not be adequately made.

The chapter is divided into four individual sections which discuss: (a) news type focus, (b) geographic focus, (c) Tribune columnist diversity, and (d) Tribune staff diversity. Each section is followed with by two tables of findings, one calculated with actual numbers, the other with percentages. 
The tables calculated with actual numbers were useful in the situation where the item count was so small that the examination of percentages alone would be misleading. This was particularly true for the diversity count of columnists. Although separate number and percentage calculations proved useful, this study still could not draw any firm conclusions about diversity levels because the number of columnists and staff writers was too small.

News Type Focus of News Coverage

The examination of news type focus during the Maynard years and between Maynard and ANG ownership periods addressed the question: What types of news did the Oakland Tribune focus on?

As stated in the historical analysis, Maynard and ANG represented different journalistic traditions, and it might be expected that the type and tradition of ownership influenced news type choices.

Looking at percentage levels (see Table 1 on pp. 132-133), there appeared to be more similarities than differences in the news type focus between ANG and Maynard. Neither ownership appeared to emphasize one type of news over another. The similarities likely were the result of how news has been defined by standard journalistic principles which transcend the organization. Although Maynard and ANG had different journalistic histories, both may have still produced news in similar ways because of larger professional standards. 
The apparent similarities in news type coverage may also have been the result of both ownerships selling to the same East Bay mass market. They had to cover the same news that the competition was covering or, for that matter, not covering.

A comparison of news type from all four years yielded fairly consistent percentages across most news categories (see Table 1 on p. 132-133). In fact there appeared to be very little variation in news type coverage among the years under Maynard (1984-85, 1987-88, 1990-91), and between Maynard and ANG (1994) ownership periods.

Among the categories receiving the greatest amount of news coverage, namely: (a) Political, (b) Planning/Environment/Traffic, and (c) Crime/Police, there were no major differences among the Maynard years nor did there appear to be any major differences between the Maynard and ANG years. For example, in the years 1984-85 and 1990-91 (both Maynard years), the Crime/Police category garnered $14 \%$ and $15 \%$, respectively of news covered. In the years 1987-88 (Maynard) and 1994 (ANG), the Crime/Police category amounted to $20 \%$ and $22 \%$, respectively. The similarities therefore were likely not linked to ownership.

In the Planning/Environment/Traffic category, there was a one-time jump in coverage up to $22 \%$ in $1987-88$ under Maynard. This was up from a steady $10 \%$ to $12 \%$ for all the other years. The increase may have been the result of shifting geographic audiences in 1987-88, under Maynard. This study counted the greatest amount of Contra Costa County news during this period. Contra Costa County which 
was largely suburban may have generated more planning-and development-related stories than urban inner city areas. Thus, as the Tribune moved out to cover the suburbs, this move was reflected by an increase in the Planning/Environment/Traffic news category.

Looking at all years of Maynard ownership, the middle year examined (198788) had the greatest amount of news. As expected, 1990-91, the year before the sale of the Maynard Tribune had the least amount of news (see "TOTAL ITEMS" category in table 2 on p. 135).

Table 1

News Type Percentages of Oakland Tribune News Coverage

\begin{tabular}{lccccc}
\hline & 1984-85 & 1987-88 & 1990-91 & \multicolumn{2}{c}{1994} \\
& Maynard & Maynard & Maynard & ANG \\
& & & & & \\
\hline 1.1. POLITICAL & $14 \%$ & $9 \%$ & $14 \%$ & $10 \%$ \\
1.1N. NAT'L POLITICS LOCALLY & 3 & 2 & 3 & 2 \\
1.12. ECONOMICS & 14 & 10 & 6 & 11 \\
1.13. SOCIAL SERVICES (SS) & 7 & 8 & 9 & 8 \\
1.13V. VOLUNTARY SS & 1 & 2 & 4 & 2 \\
1.13P. LOCAL SS PROBLEMS & 3 & 1 & 1 & 4 \\
1.14. PLAN/ENVRMNT/TRAFFIC & 11 & 22 & 10 & 12 \\
1.15. RACE/CULTURE & 4 & 4 & 5 & 4
\end{tabular}


1.2. CRIME/POLICE

1.3. ACCIDENTS

1.4. PERSONALITIES

1.5. LOCAL SPORT

1.6. EVENTS/ACTIVITIES

1.7. INFORMATION

1.8. OTHER LOCAL NEWS

3.0. GENERAL INTEREST

Features

4.1. POL./SOC./ECON.

4.15. RACE/CULTURE

4.2. LOCAL TOP/LEISURE

4.3. CONSUMER/PRICES

4.4. PERSONAL/ASSN.

4.5. SPORT

4.6. ARTS/ENTERTAINMENT

4.7. HOME FEATURES

4.8. OTHER FEATURES
14

4

7

3

5

1

1

$-$

$3 \%$

1

-.

$-$

4

$-$

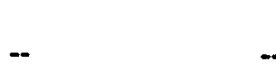

$-$

-.
20

2

3

-.

4

6

1

--
15

1

8

4

4

6

3

--

$\begin{array}{cc}1 \% & 3 \% \\ -- & - \\ 1 & 1 \\ 1 & -- \\ 3 & 3 \\ -- & 1 \\ -- & 1 \\ -- & - \\ 1 & 1\end{array}$

22

3

5

1

7

2

2

-- 
Table 2

News Type Numbers of Oakland Tribune News Coverage

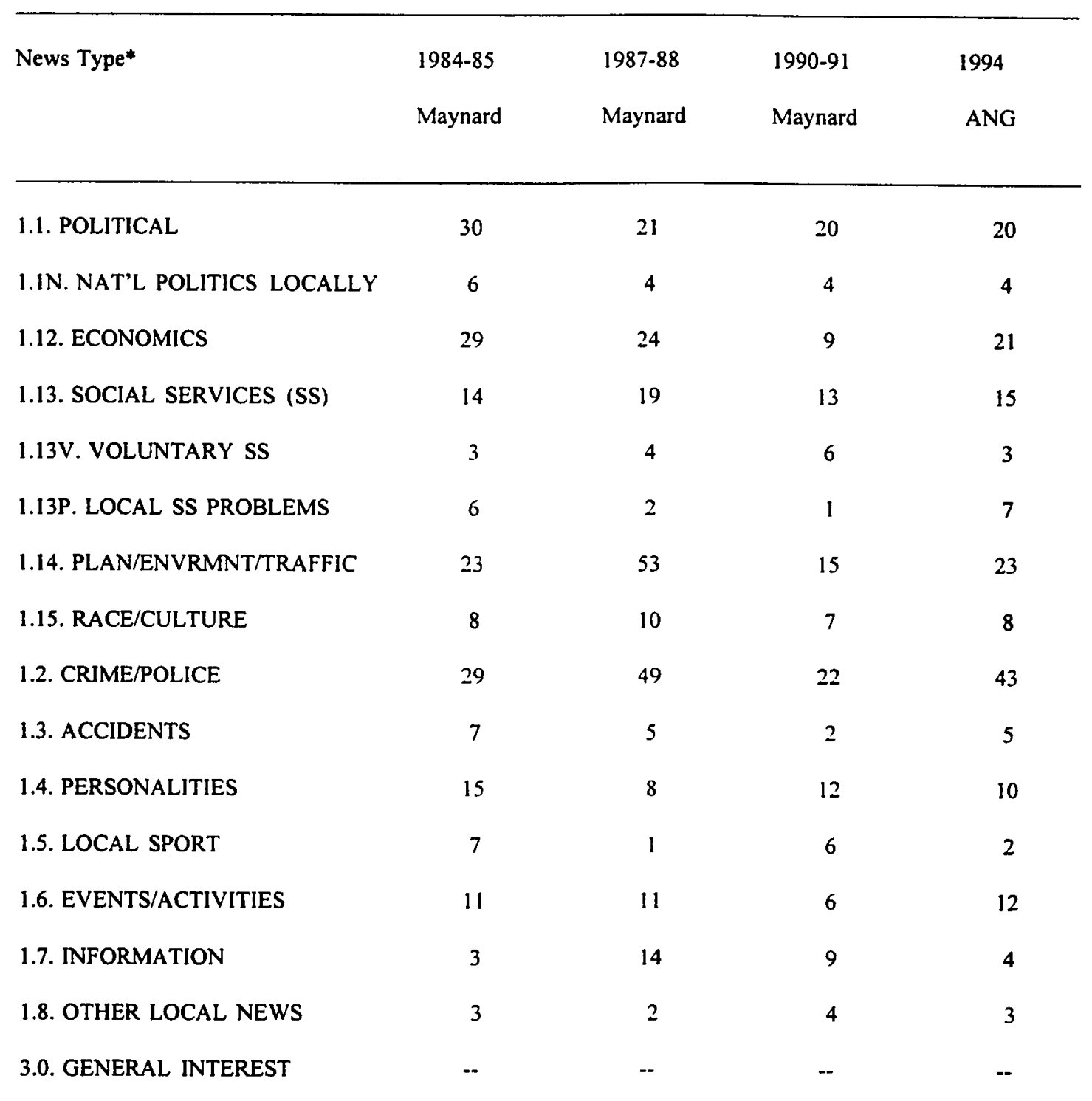


FEATURES

4.1. POL./SOC./ECON. 6

4.15. RACE/CULTURE

4.2. LOCAL TOP/LEISURE

4.3. CONSUMER/PRICES

4.4. PERSONAL/ASSN.

4.5. SPORT

4.6. ARTS/ENTERTAINMENT

4.7. HOME FEATURES

4.8. OTHER FEATURES

TOTAL ITEMS

6
3
1

8

$-$

$\cdots$

$-$

$-$

212
3

2

2

$-$

11

$--$

$-$

$-$

$-$

245
6

1

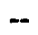

5

1

1

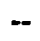

1

195

Note. * Complete descriptions of the news type categories can be found on pp. 56-59. Dashes indicate the number of items in that category was zero.

Geographic Focus of News Coverage

The examination of the geographic news focus during the Maynard years and between Maynard and ANG ownership periods addressed the questions: What communities did the Oakland Tribune cover? Did the geographic focus of news coverage change from ownership to ownership? Did it change over the nine-year period under Maynard?

As stated in earlier in the historical analysis, Maynard and ANG represented different journalistic traditions, and it might be expected that the type and tradition of each ownership may have influenced the geographic focus of news. 
The content analysis findings presented in Tables 3 \& 4 on pp. 138-139 showed that in 1994, the Oakland Tribune under ANG was focused primarily on the metropolitan core, with $56 \%$ of news coverage concentrated in the metropolitan core of Oakland, Berkeley, and Piedmont. The remaining coverage was in cities of Alameda County. ANG virtually had no news stories emanating from Contra Costa County, except for the cities of El Cerrito and Richmond in western Contra Costa County.

The geographic focus of the Tribune under Maynard showed more overall Contra Costa coverage in all three years examined, with a decline in the last full year of ownership (1990-91). Correspondingly for that year, there was an increase in Oakland-based news, which seemed to reflect the newspaper's conscious decision to refocus its efforts on the "Urban Eastshore." an area running along the Bay Area's eastern corridor from the cities of Vallejo down to Fremont.

As might be expected in an ownership with finite economic and personnel resources, coverage of the metropolitan areas and suburban areas appeared to be inversely proportional.

At least for the years 1990-91 and 1994, similarities in geographic focus between Maynard and ANG may have resulted from the constraint of being locked in by the same competitors, the San Francisco Chronicle and the Contra Costa Times. For the years, 1984-85 and 1987-88 under Maynard, and 1994 under ANG, the differences found in geographic focus may have resulted from differences in organizational structure. 
Unlike the ANG Tribune, the Maynard Tribune did not have the editorial and advertising resources of the Alameda Times-Star, the Hayward Daily Review, the Fremont Argus, or the Tri-Valley Herald available to it. The Maynard Tribune had to redesignate portions of its editorial and advertising resources to East Bay suburbs and that is reflected in the news coverage.

ANG, on the other hand, has been able to confine the Oakland Tribune's news reach to the East Bay, with very little effort in Contra Costa County. 
Table 3

Geographic Area Percentages of Oakland Tribune News Coverage

Collapsed into Metro (Oakland, Berkeley, Piedmont) and Suburban Areas.

\begin{tabular}{lllll}
\hline $\begin{array}{l}\text { Geographic } \\
\text { Area }\end{array}$ & $\begin{array}{l}1984-85 \\
\text { Maynard }\end{array}$ & $\begin{array}{l}1987-88 \\
\text { Maynard }\end{array}$ & $\begin{array}{c}1990-91 \\
\text { Maynard }\end{array}$ & $\begin{array}{c}1994 \\
\text { ANG }\end{array}$ \\
\hline Metro & $36 \%$ & $31 \%$ & $45 \%$ & $56 \%$ \\
AC $^{\text {a cities }}$ & 18 & 24 & 13 & 23 \\
Alameda Co. & 6 & 4 & 8 & 6 \\
CCC cities & 19 & 20 & 12 & 4 \\
CC County & 5 & 9 & 4 & 1 \\
East Bay & 5 & 5 & 7 & 3 \\
Bay Area & 1 & 2 & 5 & 3 \\
San Francisco & 8 & 5 & 5 & 4 \\
Other & 1 & 1 & 1 & 2 \\
\hline
\end{tabular}

Note. Percentages of 0.05 or above were rounded upward while percentages of 0.049 and below were rounded downward. Dashes indicate the number of items in that category was zero. $\mathrm{AC}^{\mathrm{a}}=$ Alameda County. $\mathrm{Co}^{\mathrm{b}}=$ County. $\mathrm{CCC}^{c}=$ Contra Costa County. CC $^{d}=$ Contra Costa. 
Table 4

Geographic Area Numbers of Oakland Tribune News Coverage

Collapsed into Metro (Oakland, Berkeley, Piedmont) and Suburban Areas.

\begin{tabular}{lcccc}
\hline $\begin{array}{l}\text { Geographic } \\
\text { Area }\end{array}$ & $\begin{array}{l}1984-85 \\
\text { Maynard }\end{array}$ & $\begin{array}{c}1987-88 \\
\text { Maynard }\end{array}$ & $\begin{array}{c}1990-91 \\
\text { Maynard }\end{array}$ & $\begin{array}{c}1994 \\
\text { ANG }\end{array}$ \\
\hline Oakland & 59 & 54 & 53 & 80 \\
Berkeley & 16 & 19 & 15 & 29 \\
Piedmont & -- & 3 & 1 & 2 \\
AC cities & 38 & 61 & 20 & 45 \\
Alameda Co. & 13 & 10 & 12 & 12 \\
CCC cities & 40 & 50 & 18 & 7 \\
CC County & 11 & 22 & 6 & 2 \\
East Bay & 10 & 12 & 10 & 5 \\
Bay Area & 3 & 4 & 8 & 6 \\
San Francisco & 16 & 12 & 7 & 7 \\
Other & 3 & 2 & 2 & 4 \\
\hline
\end{tabular}

Note. Dashes indicate the number of items in that category was zero. $\mathrm{AC}^{\mathrm{a}}=$ Alameda County. Co. ${ }^{b}=$ County. CCC $^{c}=$ Contra Costa County. $C^{d}=$ Contra Costa. 


\section{Oakland Tribune Columnist Diversity Levels}

In examining the race and gender of columnists on staff, this study attempted to answer the questions: Did the levels of diversity among staff columnists change from ownership to ownership? Did it change over the nine-year period under Maynard?

In examining the actual numbers in Table 6 on p. 143, there did not appear to be much change in the columnist diversity levels among all four years or between ownership periods.

It is important to note that in comparing diversity levels among ownership periods, under ANG's integrated organizational model, where editorial resources were shared, some columnists counted may not have been specific to the Oakland Tribune but were columnists for any of the other four ANG newspapers.

In the last two of the four years examined in Table 6 on p. 143, 1990-91 and 1994, Maynard and ANG years, respectively, there was an increase in the number of white male columnists. This was up from the first two years examined, 1984-85 and 1987-88, both Maynard years. In the same pattern, there was a drop, from two to one in the number of black female columnists.

There appeared to be more similarities between the first two years and last two years examined than there were between ownership periods. The mid-to-late $1980 \mathrm{~s}$ produced similar numbers while the years in the early 1990s had similar numbers. This may indicate another influence other than ownership. The year 1989 was a 
recessionary year for many newspapers and that fact may have been reflected in the levels of minority hiring and retention in newsrooms.

In 1990, an American Society of Newspaper Editor survey found that minority newsroom employment rose from $3.9 \%$ in 1978 to $7.8 \%$ in 1990 . Three hundred more minorities had full-time jobs, up $0.3 \%$ from the previous year. An Editor \& Publisher article noted that:

The latest figures place ASNE`s goal--making newsroom employment reflect the diversity of U.S. population by the year 2000--even further from reach. Since the goal was established in 1978 , minorities have been growing faster than whites and by 2000 could make up $25 \%$ of the population (Garneau, p. 11).

The small increases or decreases in minority leveis, or in some cases, the complete lack of some minorities as columnists at the Tribune in the 1990s may have reflected the nationwide trend. The drop may have reflected the fact that in tougher economic times, diversity goals became secondary. The falling off of minority levels may also have been compounded by hiring freezes and attrition. However, for this category, the numbers were too small to draw any definitive conclusions. 
Table 5

Diversity Percentages of Oakland Tribune Columnists

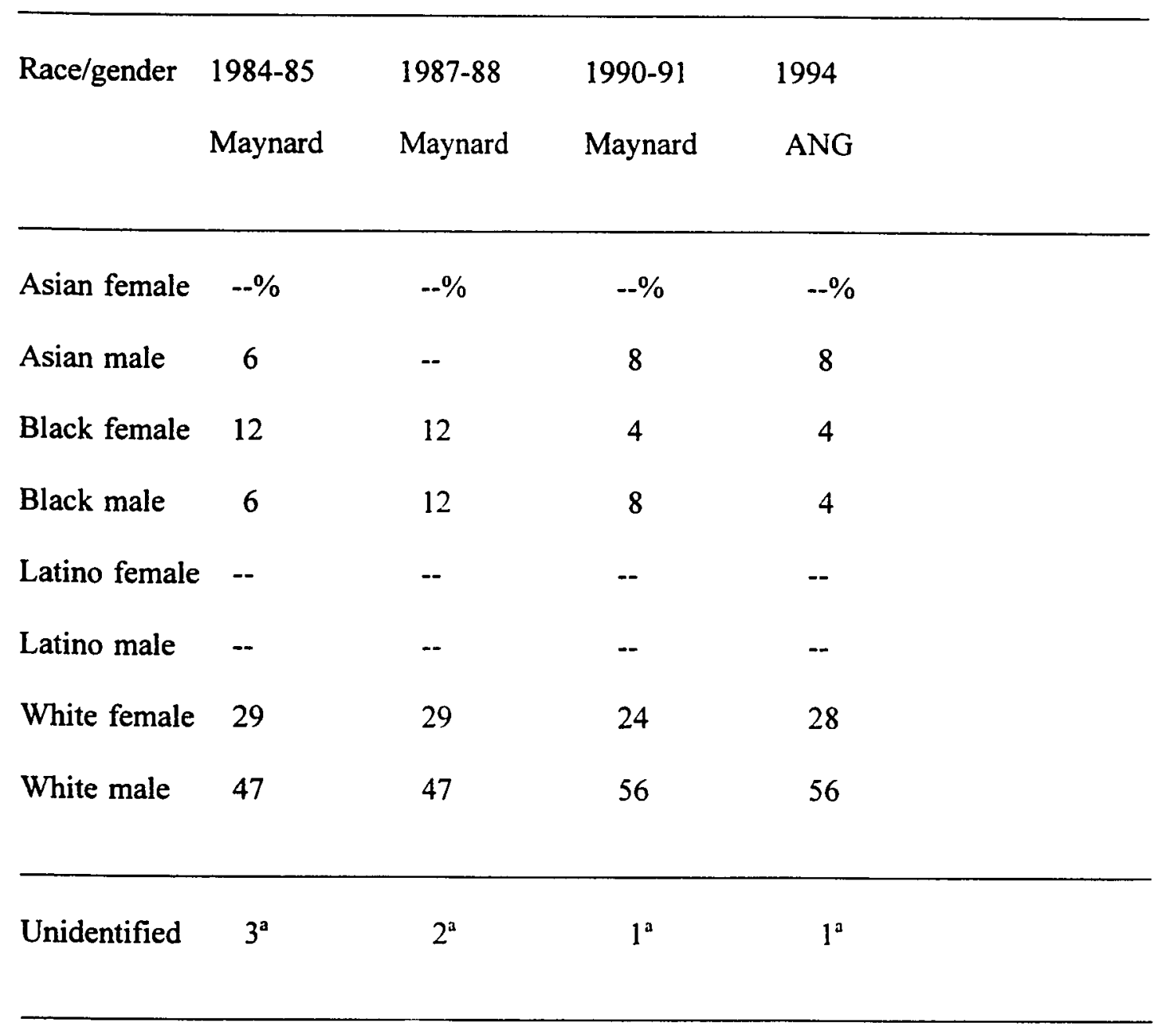

Note. Percentages of 0.05 or above were rounded upward while percentages of 0.049 and below were rounded downward. Dashes indicate the number of items in that category was zero. $\mathrm{n}^{\mathrm{a}}=$ The actual number, not the percentage. 
Table 6

Diversity Numbers of Oakland Tribune Columnists

\begin{tabular}{|c|c|c|c|c|}
\hline \multirow{2}{*}{ Race/gender } & $1984-85$ & $1987-88$ & $1990-91$ & 1994 \\
\hline & Maynard & Maynard & Maynard & $\mathrm{ANG}$ \\
\hline Asian female & -- & -- & -- & -. \\
\hline Asian male & 1 & -- & 2 & 2 \\
\hline Black female & 2 & 2 & 1 & 1 \\
\hline Black male & 1 & 2 & 2 & 1 \\
\hline Latino female & -- & -- & -- & -- \\
\hline Latino male & -- & -- & - & -- \\
\hline White female & 5 & 5 & 6 & 7 \\
\hline White male & 8 & 8 & 14 & 14 \\
\hline Unidentified & 3 & 2 & 1 & 1 \\
\hline
\end{tabular}

Note. Dashes indicate the number of items in that category was zero. 
Oakland Tribune Staff Writer Diversity Levels

In examining the race and gender of staff writers, this study attempted to answer the questions: Did the levels of diversity among staff writers change from ownership to ownership? Did it change over the nine-year period under Maynard?

In comparing diversity levels among ownership periods, it is important to point out that under ANG's integrated organizational model, some staff writers counted may not have been specific to the Oakland Tribune but were staff writers for any of the other four ANG newspapers.

It is also important to point out that at newspapers today and in the past decade, the use of interns became increasingly common as newspapers looked for ways to stretch their economic resources and provide a training ground for journalism students. As a result, a few of the bylines counted may not have been staff writers but interns. This was not a significant issue, since both ownerships made use of interns, and the inclusion of interns for the diversity count was made for both periods.

An examination of actual numbers as shown in Table 8 on p. 147 found diversity levels to be fairly stable in most categories, except for 1990-91, a year when numbers remained similar for all groups except white males who declined in numbers. Yet in looking at the percentage figures in Table 7 on p. 146, white male staff remained fairly stable. Black females were the other group that showed changes in actual numbers and percentages, with the highest levels in 1984-85 under Maynard and 
the lowest levels under ANG in 1994. On the other hand, Asian females increased their numbers from $1 \%$ to $7 \%$, from the years $1984-85$ to 1994 .

Not unlike the situation of the Tribune columnists, drops may have reflected the fact that in tougher economic times, diversity goals became less of a priority. The dropoff in minority levels may have also been compounded by hiring freezes and attrition.

Overall, looking at the percentages, in Table 8 on p. 147, from 1984 (Maynard) to 1994 (ANG), this study found an increase in the number of Asian female staff writers, a drop in the number of black female staff writers, and an increase in the number of white female staff writers under ANG. The remaining race/gender category numbers remained stable between ownership periods. Again, the sample size, although larger than the columnist sample, was too small to draw any definitive conclusions regarding diversity levels. 
Table 7

Diversity Percentages of Oakland Tribune Staff Writers

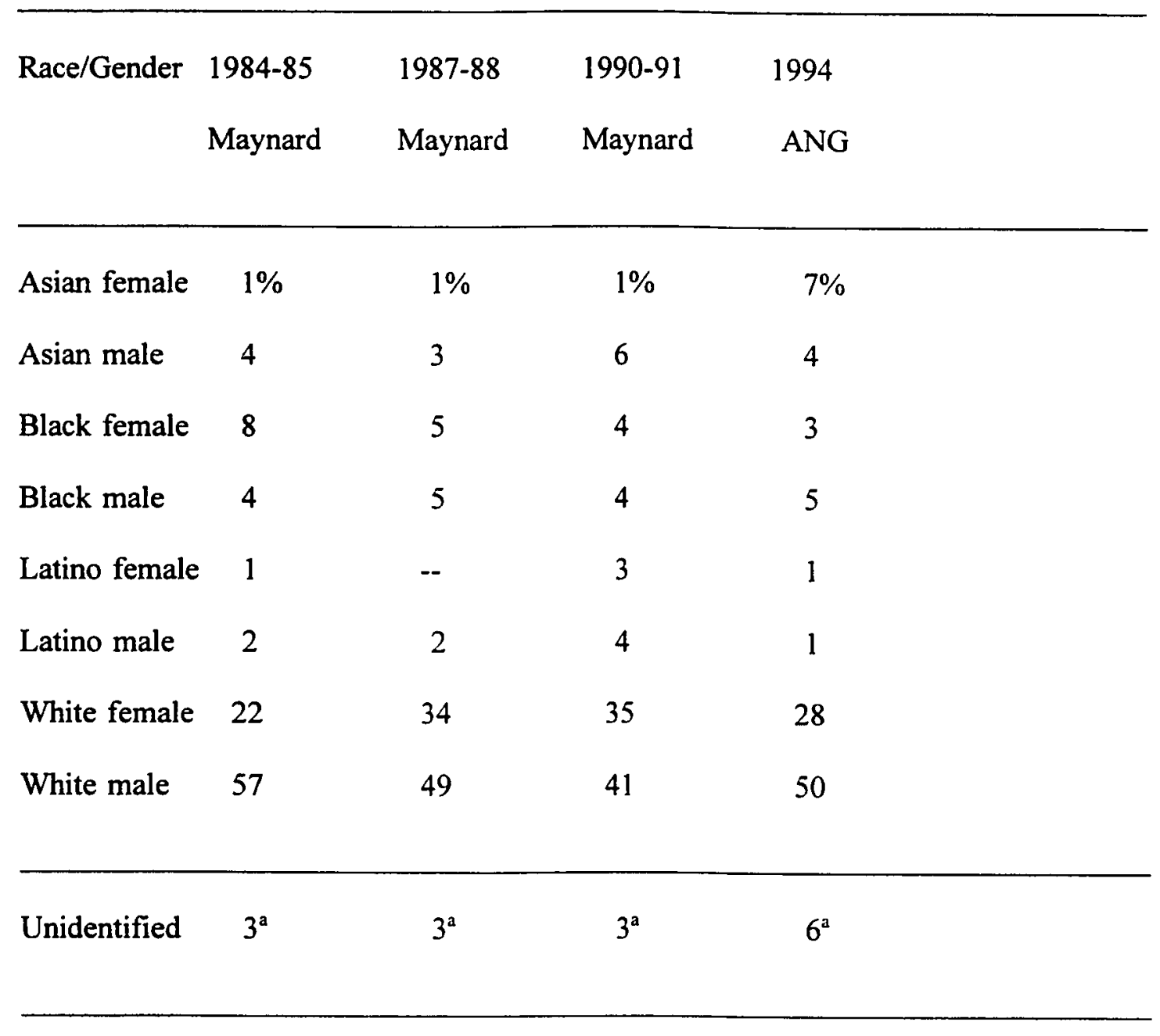

Note. Percentages of 0.05 or above were rounded upward while percentages of 0.049 and below were rounded downward. Dashes indicate the number of items in that category was zero. $n^{a}=$ The actual number, not the percentage. 
Table 8

Diversity Numbers of Oakland Tribune Staff Writers

\begin{tabular}{lcccc}
\hline & Maynard & Maynard & Maynard & ANG \\
& & & & \\
& & $1987-88$ & $1990-91$ & \\
\hline Asian female & 1 & 1 & 1 & 7 \\
Asian male & 4 & 3 & 4 & 4 \\
Black female & 7 & 5 & 3 & 3 \\
Black male & 4 & 5 & 3 & 5 \\
Latino female & 1 & -- & 2 & 1 \\
Latino male & 2 & 2 & 3 & 1 \\
White female & 20 & 31 & 24 & 28 \\
White male & 51 & 45 & 28 & 50 \\
\hline Unidentified & 3 & 3 & 3 & 6 \\
\hline
\end{tabular}

Note. Dashes indicate the number of items in that category was zero. 


\section{Chapter 8}

\section{Summary and Conclusion}

This thesis was a case study of the Oakland Tribune under the ownerships of Robert C. Maynard and the Alameda Newspaper Group. It observed the ownership transition of a metropolitan daily using an historical analysis based on current literature and 24 interviews.

Using the information derived from the interviews, the study attempted to define Maynard's editorial vision for the Oakland Tribune. Once defined, the study attempted to gauge the impact of his vision on the editorial and geographic news coverage of the Tribune in a content analysis of news type focus and geographic focus. The content analysis was also used to gauge the levels of racial and gender diversity among Tribune columnists and staff writers between ownership periods.

\section{$\underline{\text { Racial and Gender Diversity Levels }}$}

The first research question of this study asked: Did the levels of racial and gender diversity among Oakland Tribune newsroom staff and columnists change as the ownership changed?

For both categories, staff writers and columnists, the diversity count was mainly used to discern diversity patterns. The count was not used to draw any definitive conclusions about diversity levels because the resulting sample was too small for that purpose. In analyzing the actual numbers, there did not appear to be much 
change in the diversity levels of staff writers or columnists among all four years (1984-85, 1987-88, 1990-91, 1994) or between ownership periods.

However, when looking at years separately, without linking them to who was owner at the time, there appeared to be greater similarities between the first two years (1984-85, 1987-88) and last two years (1990-91 and 1994). The diversity levels in the mid-to-late 1980 s produced similar numbers while the years in the early 1990 s had similar numbers. As a whole, racial diversity levels were higher in this earlier period than in the later period. This may indicate another influence other than ownership.

The decrease in diversity levels at the Tribune in the 1990s may have reflected a nationwide trend. The drop may have reflected the tougher economic times that the Tribune and other newspapers across the country were experiencing. The falling off of diversity levels may also have been compounded by attrition and hiring freezes.

As the Oakland Tribune entered the 1990s, this study observed small increases in some of the racial categories and very small decreases in others. Again, comparisons were difficult because of the differences in ownership time frames and because of the Alameda Newspaper Group's different organizational structure.

ANG operates under an integrated organizational model, and some staff writers and local columnists counted may not have been specific to the Oakland Tribune but were staff writers for any of the other four ANG newspapers. In effect, this study was comparing a Tribune-only staff under Maynard with a collective staff of four East Bay newspapers and the Oakland Tribune under ANG. 
In summary, diversity levels at the Oakland Tribune seemed to decline slightly from the early 1980 s to the 1990 s.

\section{Total Community Coverage}

The second research question of this study was: Which communities did Maynard and ANG cover? Both ownerships covered the metropolitan core of Oakland, Berkeley, and Piedmont.

Based on the content analysis, Maynard covered much more of Contra Costa County than ANG. ANG owns the Hayward Daily Review which covers southern Alameda County and the Tri-Valley Herald which covers portions of Alameda and Contra Costa Counties. These two newspapers may be covering the areas that Maynard attempted to cover with the Tribune in the early-to mid-1980s.

On the surface, the geographic focus of both ownerships appeared to be similar. Both ownerships were mainly focused on the "Urban Eastshore," an area along the eastern corridor of the Bay Area, ranging from Vallejo down to Fremont. This study suggested that the similarities were the result of both ownerships being hemmed in by strong competition from the San Francisco Chronicle and the Contra Costa Times.

In examining the geographic focus, the study also examined news type focus. On the surface, like geographic focus, there were more similarities than differences in news type between owners. The study suggested that the similarities were the result of both ownerships applying a larger industry definition of news. 
In summary, it seemed that at least on the surface, the geographic and news type focuses of both ownership periods bore greater similarities to each other than differences. This particular research question could answered more precisely with an expanded sample.

\section{Historical Summary and Conclusion}

The answers to the above research questions provided some insight into the Oakland Tribune's manifest content. However, the answers to both questions mean little if not placed within a larger historical context.

The historical portion of this thesis attempted to place the story of the Oakland Tribune under Maynard and ANG in greater perspective by establishing the larger linkages between the metropolitan newspaper, its inner city, and outlying suburbs. It discussed the larger environmental constraints of geography, technology, and economy that both owners operated under.

The goals of each ownership were influenced and reshaped by these environmental forces in addition to different journalistic traditions and actual or perceived differences in business and editorial priorities. The historical examination showed that the Oakland Tribune, like many other metropolitan newspapers in cities across the U.S., was faced with constraints of (a) a weak local economy, (b) strong local competition from suburban dailies, and (c) dwindling readership. This study . found that all these constraints affected the objectives that comprised each owner's larger organizational vision. 
This study began its literature review by discussing a 1971 qualitative evaluation of Bay Area journalism called "A Region's Press: Anatomy of Newspapers in the San Francisco Bay Area," by Rivers and Rubin. They contended that the ingredients for a great newspaper, journalistically and economically, included (a) an owner who was determined to produce a great paper, (b) a market large enough to produce revenues enabling the owner to pay for a quality product, and (c) proper timing (p. 149).

This study found in Maynard an owner who was determined to make the Tribune a great paper, yet the market for a great paper never materialized and the effort appeared to be ill-timed.

\section{Maynard's Vision}

In 1983, when Maynard purchased the Tribune from the Gannett chain, the newspaper had experienced losses amounting to $\$ 3$ million the previous year. As many outsiders observed, it would be an uphill battle.

Maynard likely did not have any illusions about the fight that lay ahead of him, but he had a vision that he wanted to fulfill and the Tribune would serve as the vehicle. He wanted to make the Tribune a great newspaper. He wanted to implement the concepts of diversity and total community coverage that he had forcefully advocated in the past. 
Interviews revealed that Maynard had a vision of (a) total community coverage and (b) newsroom diversity. A few insiders have contended that Maynard lost sight of that larger vision in his fight to keep the Tribune afloat during his ownership.

The market for "socially conscious, quality journalism" did not materialize during the Tribune's early efforts to market the paper as "the Intelligent Alternative." An Oakland downtown revitalization that could have boosted local retail advertising was slow in coming.

Consequently, in the early part of the nine-year period under Maynard, there was a move to recuperate local advertising revenue by targeting suburban readers in Contra Costa and southern Alameda Counties. This move heated up the struggles between the business and editorial departments. which had different perceptions of who should be the Tribune audience.

The newsroom wanted to focus on the inner core of Oakland and Berkeley. The business department wanted to focus on the outlying suburban areas. As owner, Maynard was caught in the middle of this struggle.

What went on at the Tribune during this time was symbolic of the ongoing newspaper debate about providing the news people need versus the news people want. It was symbolic of the forays that many metropolitan dailies made out into the more affluent suburbs in search of upscale audiences who attracted more advertisers than poorer inner city audiences. 
As discussed in the literature. the trends of newspaper zoning and audience targeting were at work at the Tribune. The newspaper was zoned for the Contra Costa/Tri-Valley area, western Contra Costa County, and southern Alameda County. It was reported to be a huge multimillion dollar effort.

Back at the Tribune Tower, the geographic move outward to the suburbs rattled the purists in the newsroom who perceived the business department as dominating the newspaper. It became a battle between the purists who believed in the absolute separation of editorial and business departments versus a newer breed of ownermanager who believed in a greater integration of these departments.

Based on past literature and interview information, Maynard, by most accounts, started out as a purist and remained one at heart. Yet what this study observed was that being an absolute purist came easier when one was not responsible for the bottomline.

As the newspaper moved from the late 1980s into 1990, the economic environment became increasing inhospitable. By this time the newspaper had shifted its geographic focus back toward the "Urban Eastshore." This move seemed to appease the newsroom--but some in the business department had their doubts.

Media observers have contended that the entire Maynard effort was ill-timed; the series of events in the late 1980 s made it seem particularly true. There were two natural disasters: the 1989 Northern California Loma Prieta earthquake and the 1991 Oakland/Berkeley hills fire. Earlier in 1987, Maynard had been diagnosed with 
prostate cancer. He had to undergo radiation therapy which took him away from the newspaper.

The fact that Maynard was the first black to own a major metropolitan newspaper and a dynamic advocate for newsroom diversity also took him away from the newspaper. Although Maynard's reputation drew people to the Tribune, his reputation also took him away from the Tribune to make public appearances and serve on executive and association boards--this was particularly true in the early 1980 s.

Maynard's absences and his illness. although not usually discussed as contributing factors to the eventual outcome and sale of the newspaper, likely played a role.

Through it all, Maynard fought to keep the Tribune viable. Most of the interviewees endured along with him. There were buyouts. salary cuts, other concessions, and personal sacrifices made by his staff in the hope that it would allow the Tribune to go on.

In that decade, the Tribune still managed to produce several quality special reports for the East Bay that no other newspaper did. It won a Pulitzer Prize for photojournalism coverage of the 1989 Loma Prieta earthquake.

Many of those who worked with Maynard remembered him foremost as a journalist. He had the vision, but the hard pragmatism had to be learned. It is unclear whether anyone could have made the Tribune work then, considering the marketplace, 
the paper's cost structure, and the timing. It was a complicated question that this study, with its limitations, could not fully answer.

In examining the case of the Oakland Tribune under Maynard, it seemed that the overriding issue for him, as it was for many newspaper owners, was securing economic viability while preserving editorial integrity and quality.

Since becoming owner, the Alameda Newspaper Group has worked to secure economic viability for the Oakland Tribune. The economic priority of the organization has bothered some insiders who feared a decline in editorial quality. In response to the criticism of being business oriented, ANG asks: How good can a newspaper be if it no longer exists?

\section{The Alameda Newspaper Group}

When the Alameda Newspaper Group purchased the metropolitan daily in late 1992, the Oakland Tribune joined the ranks of a smaller suburban chain. To many outside media observers and insiders, it was a strange alliance. Many worried that the new owners would remold the then-118-year-old daily into a suburban newspaper, casting out the Oakland Tribune's rich history and tradition as a metropolitan daily.

Since then, the Oakland Tribune's editorial focus has remained on the metropolitan core, but the newspaper has re-emerged with a new production and economic structure. All five ANG papers, the Alameda Times-Star, the Fremont Argus, the Hayward Daily Review, the Tri-Valley Herald, and the Oakland Tribune, share editorial, advertising, and production resources. All five papers are printed in satellite 
plants located in Pleasanton and Hayward, both cities are in suburban Alameda County.

ANG has continued to emphasize that the Oakland Tribune is surviving because it is now part of a larger group of ANG-owned East Bay dailies. The new owners have said the integrated arrangement has made the Oakland Tribune profitable.

The integration has eliminated the need for zoned editions that were part of the Maynard Tribune in the mid-1980s. Instead, the outlying East Bay suburbs are covered by ANG's four other daily newspapers that are part of its group.

For the rehired Tribune employees, the new structure has imposed different deadlines and production routines that affect the ways in which they gather and edit news. Also, employees continue to work without a union contract.

With the arrival of ANG in Oakland, this study noted a philosophical change in the owner's approach to selling newspapers. There is now a greater emphasis on marketing the newspaper as a product. The literature discussed the emergence of a new breed of owner and editor who believed in a greater integration of business and editorial functions. ANG is pragmatic and business-oriented and seems to represent this new breed of owner-manager.

The Oakland Tribune today is the size of a large suburban daily, with circulation around 77,000 (see Appendix on p. 167 for circulation totals 1984/851995). It is too early in the Alameda Newspaper Group's ownership to wholly evaluate its performance. Two years proved too short a period to adequately examine the ANG 
Tribune historically or to compare it to the Maynard era. In time, the new Oakland Tribune may participate in and perhaps contribute to the much hoped for Oakland downtown revitalization. The new owners hope they will one day be recognized as enabling the survival and continuation of an important Oakland institution.

\section{Future Studies}

In examining the ownership transition of a metropolitan daily like the Oakland Tribune, this study found that the newspaper industry is in flux and being molded and reshaped to meet the future. The newspaper industry today is dealing with changing demographics, declining readership, and emerging technologies (Miller, 1992).

Online technologies present new possibilities in the way that news is gathered and retrieved. They offer opportunities to develop and market new services to readers (Bogart, 1992). Whether ANG makes the decision to invest in emerging technologies can become pivotal to its newspapers' survival. It is a question that this study could not fully address. The question presents an opportunity for a broader study of how newspapers will use technology to compete and maybe survive.

For future case studies, there are several different ways to improve on what was done here. An enlargement. perhaps doubling. of the sample size for this study's content analysis would allow for stronger interpretations. The content analysis could have also been extended to include more measures examining the more qualitative aspects of a newspaper's local news coverage. 
Finally, this Oakland Tribune story was told by a few insiders. It proved impossible to tell the complete story because there were many that were not available or willing to lend their voices. This study also did not include the views of many outsiders that had a stake in the outcome--the readers. the advertisers, and the local community. For future case studies, inclusion of these voices could shed more light on the newspaper under study.

This thesis attempted to pin down and further delineate the editorial goals of the Oakland Tribune under Maynard. It proved a huge responsibility to interpret and quantify Maynard's vision for the Oakland Tribune. It was very difficult to translate broad goals and vision into concrete measures which would allow the author to draw more definitive conclusions about the realization of that vision.

In conclusion, it seemed that Maynard possessed the vision necessary to make a great newspaper. ANG possessed the pragmatism required to run a business. The two seemed worlds apart in history and philosophy. The Oakland Tribune forced both sides to meet. It is hoped that this case study advanced the understanding of the changes occurring at U.S. metropolitan newspapers and what the industry and readers can expect in the future. 


\section{References}

American Newspaper Publishers Association. (1979). Changing needs of changing readers: A qualitative study of the new social contract between newspaper editors and readers. Reston, VA: Ruth Clark.

Bagdikian, Ben H. (1978, October). The best news money can buy. Human Behavior, pp. 62-66.

Bagdikian, Ben H. (1983). The media monopoly. Boston: Beacon Press.

Bagdikian, Ben H. (1992). The media monopoly. (4th ed.). Boston: Beacon Press.

Berelson, Bernard. (1952). Content analysis in communication research. Glencoe, IL: Free Press.

Blankenburg, William B. (1982). Newspaper ownership and control of circulation to increase profits. Journalism Quarterly. 59(3), 390-398.

Bogart, Leo. (1982). Newspapers in transition. The Wilson Quarterly, 7(5), 58-70.

Bogart, Leo. (1985). How U.S. newspaper content is changing. Journal of Communication, 35(2), 82-90.

Bogart, Leo. (1992, September). The future of newspaper revenues. The Quill, p. 39. Breed, Warren. (1955). Social control in the newsroom: a functional analysis. Social Forces, 33(4), 326-335.

Busterna, John C. (1988). Trends in newspaper ownership. Journalism Quarterly, $65(4), 831-839$. 
Busterna, John C. (1989). How managerial ownership affects profit maximization in newspaper firms. Journalism Quarterly, 6(2), 302-307. 358.

Casale, Anthony M. (1992, September). Changing news and advertising trendis. The Quill, pp. 32-33.

Casting off the chain. (1983, May 16). Time, p. 85.

The Commission of Freedom of the Press. (1947). A free and responsible press: $A$ general report on mass communication: newspapers, radio, motion pictures, magazines, and books. Chicago: University of Chicago Press.

Compaine, Benjamin M. (1980). The newspaper industry in the 1980s: an assessment of economics and technology. White Plains. NY: Knowledge Industry.

Compaine, Benjamin M., Sterling, Christopher H.. Guback. Thomas, \& Noble, Jr., J. Kendrick. (1982). Who ouns the media? (2nd ed.). White Plains, NY: Knowledge Industry.

Crutcher, Lawrence M. (1992, September). Signs look good for advertising upturn. The Quill, p. 40.

Davison, W. Phillips, Boylan, James, \& Yu, Frederick T.C. (1982). Mass media: systems and effects. New York: Holt, Rinehart \& Winston.

Demers, David P. (1991). Corporate structure and emphasis on profits and product quality at U.S. daily newspapers. Journalism Quarterly, 68(1/2), 15-27. 
Donohue, George A., Olien. Clarice N., \& Tichenor, Phillip J. (1985). Reporting conflict by pluralism, newspaper type and ownership. Journalism Quarterly, 62(3), 489-499, 507.

Endicott, William (1979. December 18). Oakland Tribune pins its hopes on Morning 'Peach' in bid for new' life. Los Angeles Times. pp. 1, 10.

Garneau, George. (1990, April 14). All-white newsrooms remain all-white. Editor \& Publisher, pp. 11, 37.

Gelman, David, \& Joseph. Nadine. (1983, May 16). An editor's coup in Oakland. Newsweek, p. 93.

Goodman, Mike. (1974, February 24). William F. Knowland, publisher and ex-senator, found dead. Los Angeles Times, pp. 1. 5-6.

Greenberg, Bradley S., Burgoon. Michael. Burgoon, Judee K., \& Korzenny, Felipe. (1983). Mexican Americans and the mass media. Norwood. NJ: Ablex.

Groups still own most U.S. dailies. (1984. April 28). Editor \& Publisher, pp. 76, 78, 80.

Haws, Dick. (1991). Minorities in the newsroom and community: a comparison. Journalism Quarterly, 68(4), 764-771.

Holing, Dwight. (1984, June). Pressing Business. San Francisco Focus, pp. 48-51, 126-127.

Hornby, William H. (1976, January). Beware the 'market' thinkers . . . are newspapers forgetting they're in the news business? The Quill. pp. 14-17. 
Hynds, Ernest C. (1980). American newspapers in the 1980s. New York: Hastings House.

Jackson, Harold. (1992). We weren't listening. Nieman Reports, 46(2), 15-16.

Kleinfield, I.R. (1979, April 8). The great press chain. The New York Times Magazine, pp. 45-63.

McClatchy, C.K. (1988). How newspapers are owned--and does it matter? Nieman Reports, 42(2), 19-24.

McGrath, Mike. (1988, March 11). The Strange Case of the Oakland Tribune. Express, pp. 1, 12-20.

McGrath, Mike. (1988, March 18). The Strange Case of the Oakland Tribune, Part Two. Express, pp. 1, 9-16.

McQuail, Denis. (1977). Analysis of newspaper content. London: Royal Commission on the Press.

Miller, Edward D. (1992, September). Where is design leading us? The Quill, pp. 2425.

A message to Tribune readers/The Tribune in transition: A newspaper for the 21st century. (1990, June 21). The Tribune, p. B-7.

Oakland Tribune: Count on it. (1991, February 26). The Oakland Tribune, p. A-9. Oakland Tribune Staff. (1992, December 1). Welcome to the new Oakland Tribune. The Oakland Tribune, p. A-1. 
Oakland Tribune Staff. (1995. March 31). Tribune taps three for top editors' positions. The Oakland Tribune, p. A-3.

Our son scored the winning touchdown. Tell everyone! If it's news to you, make sure it's in the Oakland Tribune. (1992, December 1). The Oakland Tribune, p. A-5. Prichard, Peter. (1987). The making of McPaper: the inside story of USA Today. Kansas City, MO: Andrews, McMeel \& Parker.

Rapaport, Richard. (1989, September). Newspaper Wars. Part 1. San Francisco Focus, pp. 91-122.

Rapaport, Richard. (1989, October). Newspaper Wars, Part 2. San Francisco Focus, pp. 125-156.

Rivers, William L., \& Rubin, David M. (1971). A region's press: anatomy of newspapers in the San Francisco Bay Area. Institute of Governmental Studies: University of California. Berkeley.

Romanow, Walter I., \& Soderlund. Walter C. (1988). Thomson Newspapers' acquisition of The Globe and Mail: a case study of content change. Gazette, 4l(1), 5-18.

Sachsman, David, \& Sloat, Warren. (1985). The press and the suburbs: the daily newspapers of New Jersey. New Brunswick, NJ: Center for Urban Policy Research.

Say good morning to a greater metropolitan newspaper. (1982, October 23). The Tribune, p. A-4. 
Schardt, Arlie, \& Reese, Michael (1979, September 24). Oakland's new look.

Newsweek, p. 89.

Shaw, David (1979, September). The news mogul who would be famous. Esquire, pp. 63-70.

Staats, Craig. (1983, May 1). It's a breakaway for Maynard and Trib. The Tribune, p. A-12.

Standard Rate and Data Service. (1984/85-1989/90). Newspaper circulation and analysis. Skokie, IL: Standard Rate and Data Service.

Standard Rate and Data Service. (1992-1995). Newspaper circulation and analysis. Skokie, IL: Standard Rate and Data Service.

Stark, Rodney W. (1962). Policy and the pros: an organizational analysis of a metropolitan newspaper. Berkeley Journal of Sociology. 8(3), 11-31.

Stein, M. L. (1992, October 24). Oakland Tribune sold. Editor \& Publisher, pp. 38-39, 46.

Thrift, Ralph R., Jr. (1977). How chain ownership affects editorial vigor of newspapers. Journalism Quarterly, 54(2), 327-331.

Tong, David. (1983, May 1). New era at The Tribune. The Tribune, pp. A-1, 14.

Tribune Marketing Department. (1990, June 27). Trib Combines Local Sections. F.Y.I, pp. 1-2.

Tribune Staff. (1988, February 12). Nancy Maynard joins The Tribune. The Tribune, pp. C-1, 6 . 
Tribune Staff. (1991, February 26). The Tribune heralds a new beginning. The Tribune, pp. A-1, 4.

Tribune Staff. (1991, February 26). Trib is coming home. The Tribune, p. A-1.

Underwood, Doug, \& Stamm. Keith. (1992). Balancing business with journalism: newsroom policies at 12 West Coast newspapers. Journalism Quarterly, 69(2), 301-317.

UpClose San Francisco Bay Area: community location guide. (1991). San Mateo, CA: UpClose Publishing.

Wilson II, Clint C., \& Gutierrez. Felix. (1985). Minorities and media: diversity and the end of mass communication. Newbury Park. CA: Sage. 
Appendix: Individual Circulation Figures 1984/85-1995 for the Oakland Tribune and the ANG newspapers

\begin{tabular}{llllll}
\hline Year & $\begin{array}{l}\text { Oakland } \\
\text { Tribune }\end{array}$ & $\begin{array}{l}\text { Alameda } \\
\text { Times- } \\
\text { Star }\end{array}$ & $\begin{array}{l}\text { Hayward } \\
\text { Daily } \\
\text { Review }\end{array}$ & $\begin{array}{l}\text { Fremont } \\
\text { Argus }\end{array}$ & $\begin{array}{l}\text { Tri- } \\
\text { Valley } \\
\text { Herald }\end{array}$ \\
\hline $1984-85$ & 155,269 & & 45,696 & 21,929 & \\
$1985-86$ & 146,562 & & 46,007 & 22.392 & \\
$1986-87$ & 149,704 & & & & \\
$1987-88$ & 151,669 & & & & \\
$1988-89$ & 149,256 & & & & \\
$1989-90$ & 147,570 & & 43,026 & 32,377 & 35,079 \\
$1990-91$ & 115,296 & 7.367 & 43,296 & 31,695 & 34,467 \\
1992 & 107,407 & 7,329 & 44,069 & 31,984 & 36,149 \\
1993 & 90,093 & 6.946 & 40,814 & 31,604 & 34,054 \\
1994 & 76,749 & 6.564 & & & \\
1995 & & & & & \\
\hline
\end{tabular}

Note. Data from "Newspaper circulation and analysis," by Standard Rate and Data Service (SRDS). (1984/85-1989-90, 1992-1995). Skokie, IL: Standard Rate and Data Service. SRDS data for total circulation was obtained from Audit Bureau of Circulations $(\mathrm{ABC})$ annual audit and date audit. 